UNIVERSIDADE DE SÃO PAULO

FACULDADE DE FILOSOFIA, LETRAS E CIÊNCIAS HUMANAS

DEPARTAMENTO DE LETRAS MODERNAS

PROGRAMA DE PÓS-GRADUAÇÃO EM ESTUDOS LINGUÍSTICOS E LITERÁRIOS EM INGLÊS

MÁRCIA PEDREIRA

VOZES NARRATIVAS EM A DISTANT SHORE

DE CARYL PHILLIPS

São Paulo

2008 

UNIVERSIDADE DE SÃO PAULO

FACULDADE DE FILOSOFIA, LETRAS E CIÊNCIAS HUMANAS

DEPARTAMENTO DE LETRAS MODERNAS

PROGRAMA DE PÓS-GRADUAÇÃO EM ESTUDOS LINGUÍSTICOS E LITERÁRIOS EM INGLÊS

\section{VOZES NARRATIVAS EM A DISTANT SHORE DE CARYL PHILLIPS}

MÁRCIA PEDREIRA

Tese apresentada ao Programa de Pós-Graduação em Estudos Linguísticos e Literários em Inglês do Departamento de Letras Modernas da Faculdade de Filosofia, Letras e Ciências Humanas da Universidade de São Paulo para obtenção do título de Doutor em Letras.

Orientadora: Profa. Dra. SANDRA GUARDINI VASCONCELOS

São Paulo

2008 
Aos meus irmãos, Haroldo e Marilda 
RESUMO: Através do manejo do foco narrativo,dentre outros recursos literários, o Autor alterna e entrelaça narrativas de experiências de personagens oriundas de formações culturais diferentes com a representação do pensamento de cada uma delas sobre o passado, sobre si, sobre o outro e sobre vários espaços em que atuam. Esses espaços se revelam incongruentes com a idéia de um "mundo sem fronteiras" conforme se apregoa na modernidade tardia. O objetivo desta tese é discutir como aspectos do real histórico e do real psicológico nos tempos em que vivemos se sedimentam na forma deste romance contemporâneo

Palavras-chave:

cruzamento de perspectivas; heteroglossia; emigração e imigração;

entrechoque de formações ideológicas; representação do real histórico e do real psicológico.

ABSTRACT: Through shifts in point-of-view, among other literary resources, the Author alternates and intertwines narratives of the experiences of two characters from contrasting cultural formations with narratives of their thoughts about the past, themselves, each other and the various settings in which they act. These spheres are rendered as incongruent with the idea of a "world without borders", so often celebrated in late modernity. The aim of this thesis is to discuss how elements of present-day historical and psychological experience solidify in the form of this particular contemporary novel.

Key words:

criss-crossing perspectives ; heteroglossia ; emigration and immigration ; clash of ideological formations ; rendition of historical experience and psychological experience 


\section{ÍNDICE}

1. INTRODUÇÃO........................................................

2. UM NOVO EMPREENDIMENTO..............................

3. LIBERDADE PELO AR................................................32

4. ESPERANÇA..............................................................100

5. CONCLUSÃO........................................................116

6. BIBLIOGRAFIA......................................................119 


\section{INTRODUÇÃO}

A maior parte da obra de Caryl Phillips está vinculada à necessidade de repensar a história, de nos determos de maneira aprofundada em épocas, conflitos e situações humanas que nos interpelam de algum modo. Phillips é um autor prolífico e desde os anos setenta publicou nove romances, três peças teatrais, roteiros para cinema e rádio, duas obras de nãoficção e vários artigos em jornais e revistas, além de ter editado uma antologia de textos literários em língua inglesa.

Destacam-se em sua ficção dois conjuntos principais. Os dois primeiros romances tratam diretamente da situação de uma pequena ilha no Caribe e das relações coloniais, seja sob o enfoque da imigração de um jovem casal e seu bebê para a mãe-pátria em The Final Passage (1985) ou do retorno à terra natal em vias de se tornar nação independente por um adulto dela afastado há vinte anos em $A$ State of Independence (1986). Ambos os romances lidam com a complexidade e as limitações que a relação colonial impõe a homens e mulheres e a forma como se sobrevive a elas. São romances de início de carreira e estão vinculados à biografia e à formação do escritor. Já os romances publicados a partir de 1990, acrescidos de The Higher Ground (1989), formam um conjunto que exibe envergadura muito mais abrangente e no qual o material histórico (fruto de pesquisas em épocas relativamente distanciadas) é possível de ser reconhecido e localizado pelo leitor. São romances de grande inventividade, especialmente no que tange à criação de linguagens específicas para as personagens.

A Distant Shore, publicado em 2003, foge da integração nesse segundo conjunto. Apresenta a justaposição e intersecção das histórias de vida de duas personagens oriundas de formações sociais contrastantes, Dorothy Jones e Solomon Bartholomew. Constitui-se de quatro segmentos narrativos articulados segundo a esfera de atuação de cada uma das personagens, segmentos estes apresentados sob forma quiasmática, em $\mathrm{X}$, no que se refere ao emprego do foco narrativo, o que resulta em maior alcance nos reflexos e refração de significados que se abrem à interpretação.

Os dois primeiros segmentos que abordam a vida de Dorothy, o primeiro e o terceiro, 
são respectivamente uma narrativa homodiegética - feita em primeira pessoa do singular, discurso de um narrador presente dentro da ficção, narrador-personagem - e narrativa heterodiegética - feita em terceira pessoa do singular, por um narrador posicionado fora da ficção, numa enunciação que causa a impressão de relato objetivo, porém, com ângulo de focalização predominantemente aderente à perspectiva da personagem ("visão com"), mas que pode também afastar-se em determinados pontos, de modo a abrir espaço para o leitor fazer sua interpretação e mesmo chegar à constatação de que a sensibilidade de Dorothy sofre progressiva agudização ao longo do enredo até aproximar-se da alienação mental.

Nos dois segmentos referentes ao protagonista masculino, vê-se recurso semelhante, mas ao contrário. O segundo segmento, sobre o africano Gabriel, é feito através de narrativa heterodiegética, por um narrador em terceira pessoa do singular, grande parte do tempo caracterizado pela "visão com" o protagonista, mas em muitos momentos dele afastado, para que se possam retratar com maior perspicácia os preconceitos e as diferenças culturais, as diferentes formas de decodificação das práticas sociais, o que não teria impacto tão preciso se a narrativa viesse somente da visão da personagem em primeira pessoa. O quarto segmento, sobre a vida do mesmo africano que passou a se chamar Solomon, utiliza a mesma focalização narrativa que se apresentou no primeiro para Dorothy, só que se trata agora do discurso de um narrador-personagem de dentro da ficção, o que é fundamental para que toda a nova vida no norte da Inglaterra, as esperanças, a visão do Ocidente e a realidade nele vivida nos sejam dados pelo pensamento do estrangeiro.

Em resumo, vêem-se formas narrativas colocadas em alternância: o primeiro e o quarto segmentos, num esquema homodiegético que permite o aprofundamento no ângulo de visão de Dorothy e de Solomon, respectivamente; o segundo e o terceiro segmentos, em esquema heterodiegético, com maior flexibilidade na abertura e fechamento da angulação para que aflorem com mais força as alusões, os subentendidos, os preconceitos explicitados ou não e para que se construam claramente o ostracismo e a alienação que uma e outra personagem sofrem na modernidade tardia, num mundo apregoado como espaço sem fronteiras.

O jogo dos discursos provenientes de diferentes posições de sujeito e o efeito dos silenciamentos, pressupostos e omissões, acrescidos da quebra de linearidade temporal são recursos bem utilizados no interior de cada segmento e na ordenação dos mesmos no todo, capazes de produzir efeitos de estranhamento, mas também de clareza e reconhecimento e, ao 
mesmo tempo, inscrever esta obra de ficção numa variante atualizada do romance realista contemporâneo. ${ }^{1}$

Em The Souls of Black Folk ${ }^{2}$ E.W. Du Bois afirmou que o problema do século XX seria o preconceito e hoje, passados quase cem anos dessa afirmação, iniciado já o século XXI, com os acontecimentos da explosão das torres gêmeas em Nova Yorque em 2001, os ataques aos centros de Madri e de Londres em 2005, as ingerências das forças americanas e inglesas no Iraque, com o fortalecimento da hegemonia americana e seu relativo isolacionismo, com a insistência em se estabelecer uma unidade européia apesar de haver tantos pontos de fragilidade - a desconfiança e incompreensão entre as civilizações desenvolvidas do Ocidente e as do Oriente, o pouco-caso reservado aos países da América Latina e o quase total desinteresse em relação aos países da África ao sul do Saara --, pode-se ver que estamos bem longe de dizer que o problema do preconceito, aliado a tantos outros que acarreta, tenha sido superado. Ao contrário, agravou-se bastante a questão com o aumento dos contingentes populacionais em busca de asilo político, de refúgio da guerra, da seca, de desastres ecológicos, das perseguições étnicas, etc.. No final do século XX e nesta primeira década do XXI os jornais e os meios de comunicação focalizam as grandes dificuldades relativas aos movimentos migratórios pelo mundo e as barreiras impostas contra a entrada de imigrantes, as ocasionais tentativas de regulamentação nos países avançados dos que imigraram ilegalmente ou então as medidas de deportação sumária. Por sua vez, a arte do cinema tem igualmente voltado a atenção ao drama dos que buscam a sobrevivência em uma peregrinação fora de sua terra natal. Vale mencionar o "super-realismo" no filme "In this World", produção inglesa de 2002, dirigido por Michael Winterbottom, através do qual se apresenta o extremo esforço de dois refugiados afegãos para chegarem à Europa abastada. Outro exemplo é dado por "Va, Vis et Deviens", produção franco-israelense de 2004, dirigido por Radu Mihaileanu, em que uma mãe africana de cultura muçulmana força o filho a dela se separar para que ele tenha a possibilidade de sobreviver fora do campo de refugiados no Sudão, assumindo falsa identidade judaica. E ainda outro é o de "Si le vent soulève les sables”, produção belgo-francesa de 2006, dirigido por Marion Hansel e baseado no romance Chamelle de Marc Durant Vallois, que retrata a emigração forçada de uma família africana.

1 Não se trata aqui do "Realismo" como escola literária do século XIX, mas como uma possibilidade de criação artística que ultrapassa os limites do movimento, existindo mesmo antes e depois dele. Vários aspectos dessa questão encontram-se em "Um problema crítico" de Sandra Guardini Vasconcelos nA Formação do Romance Inglês. Ensaios Teóricos. São Paulo: Editora Hucitec e Fapesp, 2007, p.42-62.

2 Du Bois, W. E. B.. The Souls of Black Folk. Londres: Dover Publications, 1994. 
São essas algumas das preocupações históricas fundamentais do tempo em que vivemos e é profundamente atento a elas que Caryl Phillips criou o romance de ficção objeto deste estudo. Com publicação em 2003, anterior às explosões nos ônibus e trens de metrô no centro de Londres em julho de 2005, não é errado observar, conforme consta em um dos comentários da contra-capa, que A Distant Shore tenha como principal foco a busca de refúgio e segurança. De fato, há duas personagens que percorrem trilhas muito distintas em busca de paz. Como elas vêm de formações e origens muitíssimo diferentes, a trajetória de uma será iluminada pela trajetória da outra e vice-versa, de forma que uma ironia constitutiva e verdadeiramente triste recobrirá o todo que sustenta os movimentos de aproximação e afastamento entre Solomon e Dorothy. A tristeza advém da incongruência que o mundo exterior projeta sobre os dois e que os distancia quando haveria proveito, não só na esfera restrita das vidas de cada um, se um vínculo mais forte se estabelecesse e se projetasse no exterior.

O impacto da cultura de uma civilização sobre outra e vice-versa não é assunto novo no gênero literário do romance. Com Bakhtin ${ }^{3}$, sabemos da presença constitutiva da polifonia antes mesmo de Dom Quixote de Cervantes. Mais perto de nossa época há vários exemplos, dos quais destacamos os romances em língua inglesa, em que se aborda o choque de culturas e a possibilidade de transculturação, entendida aqui como transformaçao que incorpora e integra aspectos de uma cultura alienígena. Vêm à lembrança Robinson Crusoe de Daniel Defoe, A Passage to India de E.M. Foster, Wide Sargasso Sea de Jean Rhys, The Remains of the Day, de Kazuo Ishiguro e Foe, de J. M. Coetzee. A propósito, o próprio Caryl Phillips, organizou e prefaciou a antologia Extravagant Strangers ${ }^{4}$, em que desmistifica a noção de que somente nos últimos tempos tenha havido uma revigoração do cânone da literatura inglesa graças à participação de autores nascidos fora da Grã-Bretanha e reitera a idéia de que já há pelo menos duzentos anos a literatura inglesa tem sido moldada e influenciada por escritores de fora da nação.

Com as transformações por que passou o mundo ocidental desde os anos das décadas de 1980 e 1990, com o estabelecimento de medidas políticas e econômicas para o fortalecimento do que se convencionou chamar de globalização e, visto que ocorrem e se intensificam transferências de contingentes humanos através de nações e continentes, sejam

3 Bakhtin, Mikhail. "Discourse in the Novel”. In: The Dialogic Imagination. Ed. e trad. De Michael Holquist. Austin: University of Texas Press, 1990.

4 Phillips, Caryl. Extravagant Strangers. Nova Yorque: Vintage International, 1999. 
essas transferências realizadas de forma branda, com o consentimento legal dos países que os recebem, ou de forma clandestina e difícil, com o repúdio institucional e social por parte dessas mesmas nações, com tudo isso, acrescido das conseqüências sociais que acarreta, o assunto do choque de mentalidades, também chamado de choque cultural, tornou-se matéria temática de grande interesse para a prosa de ficção, para teóricos e críticos das Ciências Humanas.

Os estudiosos adeptos ou simpatizantes dos chamados Estudos Culturais e da Teoria Pós-Colonial atuando em vários campos das Ciências Humanas - pensamos aqui em autores como Salman Rushdie na literatura, Stuart Hall e James Clifford na sociologia e na antropologia, Homi K. Bhabha na teoria literária, para citar alguns - se empenharam em divulgar e enaltecer conceitos como os de "transnacionalidade", "transculturação", "hibridismo" e a celebração de uma suposta capacidade que as pessoas comuns do povo têm de subverter a ordem imposta e de até rir do poder opressor exercido sobre si. Os seguidores dessa perspectiva teórica encontram a oportunidade de ligar aspectos de seu arcabouço ideológico à ficção de Caryl Phillips. Na internet é possível achar vários estudos que se apóiam nessa teoria ${ }^{5}$. De meu conhecimento, não há ainda um estudo desses sobre o romance A Distant Shore, mas imagino que, se houvesse, seria provavelmente um enfoque a destacar uma visão positiva que o romance comportaria sobre o significado do vínculo estabelecido entre os protagonistas, seres oriundos de mundos extremamente diferentes.

Outros estudiosos, mais apegados a uma visão convencional da Sociologia da Literatura, poderiam se ater ao retrato das instituições, das relações sociais e da crítica presentes em todo o romance, estabelecendo associações entre o lebenswelt (o mundo da obra), a ficção criada e a realidade do nosso mundo no século XXI, que a possa ter inspirado. Haveria aqui a crença de que o mundo exterior encontraria representação especular no romance.

No Brasil encontramos na linha crítica fundada por Antonio Cândido e seguida por muitos discípulos, a orientação de buscar na expressão formal da obra a articulação entre literatura e sociedade, de descobrir a interpenetração entre o processo histórico e o modo de ser das obras literárias, de "passar da linguagem ao mundo e do mundo à linguagem", de verificar que "a forma aproveita e sintetiza determinados movimentos, que são movimentos da História"6, de ver a forma travejada de História.

5 Ledent, Bénédicte. Do Departamento de Inglês da Universidade de Liége na Bélgica e em b.lent@ulg.ac.be. 6 Arrigucci Junior, Davi. “Entrevista com Davi Arrigucci Jr.” Magma - Revista. São Paulo: Humanitas, 1997, 
Como os demais romances de Caryl Phillips, A Distant Shore se constitui de segmentos narrativos, cada um dos quais capaz de conter uma unidade de sentido com começo, meio e fim, que, justapostos e inseridos no todo maior da narrativa completa, o romance propriamente dito, adquirem novos sentidos. Devido à forma dividida em segmentos que podem fornecer uma unidade caleidoscópica ${ }^{7}$, os romances desse autor induzem o leitor atento e o estudioso a terem o desejo de lidar com as partes simultaneamente porque o seu efeito final tem um caráter abrangente, mas a literatura é feita de linguagem e esta impõe o desenrolar dos enunciados passo a passo no tempo e a necessidade de se escolher uma via de aproximação e ordenar os resultados.

Há muitos caminhos a seguir na análise desse romance, tais como a temática de especial relevância para os nossos dias, a não-linearidade e a relativa fragmentação da narrativa, a indução e provocação do raciocínio do leitor para que forme sentidos e interprete, a obtenção de simplicidade na linguagem utilizada de forma que a escrita pareça ser fácil e escorreita, a clara opção em não visar a hermetismos, em não criar grandes obstáculos à compreensão. Todos esses recursos utilizados conferem a A Distant Shore a característica de ser uma obra realista compatível com as formas contemporâneas que o romance, como forma literária, soube incorporar em seu arcabouço.

Esse romance se apóia sobre dois pilares principais constituídos pelos protagonistas, Dorothy Jones e Solomon Bartholomew. Cada um dos segmentos se destina a apresentar a sua história e esfera de atuação social. Um fio condutor de especial relevância que amarra os inúmeros episódios internos e os segmentos vem a ser a narrativa da relação entre os protagonistas e a sugestão do que poderia ter sido se tivesse havido outras condições de vida, se se tratasse de outro mundo, um mundo em que as relações entre a Europa e a África fossem bem diversas do que são na nossa atualidade. A idéia por vezes utópica de aproximação e interpenetração, de influência mútua, de maior possibilidade de entendimento ou embate mais produtivo desses mundos subjaz à narrativa toda.

O universo do romance gira em torno das diferenças em maior ou menor grau existentes entre as experiências, valores e visões de mundo dos protagonistas e da maior ou menor possibilidade de aproximação, convivência e articulação de ambos. Fundamental é o movimento que se estabelecerá ao longo de toda a narrativa, efetuado através da relação inter-

$\mathrm{n}^{\circ} 4$, p. 17 e p. 21.

7 Lodge, David. The Novelist at the Crossroads. Londres \& Nova Yorque: Routledge,1986. David Lodge denomina esse tipo de composição de "romance origami". 
subjetiva entre esses protagonistas, o desenvolvimento e entendimento dela na mentalidade de cada um e a possibilidade de repercussão dessa mesma relação na esfera do mundo criado na obra, que caberá ao leitor avaliar.

A relação entre Dorothy e Solomon está marcada, paradoxalmente, por fragilidade e por força: fragilidade no plano concreto das ações representadas, fragilidade que quase determina a sua inexistência, pois se trata da relação de uma amizade curta que se desenvolve brevemente no tempo e na ação, truncada pouco antes de se consolidar; força, porque consegue irromper e se estabelecer contra as expectativas externas da convenção social e porque, no plano da vida psíquica, é abertura para uma relação autêntica, de interesse mútuo genuíno, pautada pela busca e oferta de solidariedade.

Os dois primeiros segmentos formam uma unidade inquestionável devido à complementaridade subjacente que transferirá luz de um para o outro e vice-versa: o primeiro abarca a história de Dorothy e o segundo, a de Gabriel. Colocados em adjacência, técnica típica utilizada por Caryl Phillips $^{8}$, os segmentos potencializam os sentidos e idéias pertinentes a cada um e ampliam os significados que um contra o outro e juntos conseguem projetar. Esse ponto, a irradiação de sentidos, estará presente ao longo da análise dos segmentos.

8 Estudei o efeito da composição de Crossing the River na dissertação de mestrado intitulada "Trilhas pela água:história e ficção em Crossing the River de Caryl Phillips", defendida em fevereiro de 2003. 


\section{UM NOVO EMPREENDIMENTO}

Com aproximadamente setenta páginas, o primeiro segmento é um percurso narrativo que o leitor empreenderá levado pela mão de Dorothy, orientado pelo seu ponto de vista. A narrativa em primeira pessoa possibilita que se escancarem os pensamentos da personagem e que tudo seja visto de sua perspectiva. Trata-se de uma escolha do autor, capaz de repercutir duplamente sobre o leitor. Tendo a sua formação social moldada em um país desenvolvido do ocidente, a Inglaterra, apoiada nas suas instituições e tradições, Dorothy experimenta e mostra ao leitor a solidez e as fissuras desse mundo. Por ter a função dupla de narradora e de personagem, Dorothy apresenta-se a um tempo capaz de exercer uma visão crítica do que a rodeia e também é vítima do cerceamento exercido no contexto da sociedade em que vive.

A escolha do ponto de vista de Dorothy para a abertura do romance (será também sob esse ponto de vista que o quinto segmento se fechará) revela-se como escolha muito apropriada porque é de se supor que a maioria dos leitores de Caryl Phillips estejam mais familiarizados com as práticas sociais do mundo ocidental, estejam eles situados nos centros mais desenvolvidos de países do hemisfério norte, nas regiões consideradas periféricas dentro desse mesmo espaço (o chamado Terceiro Mundo incrustado no Primeiro) ou estejam eles em camadas do Terceiro Mundo, provenientes ou conhecedores da experiência urbana desfavorável da contemporaneidade. Será mais fácil para esses supostos leitores adentrarem as questões apresentadas na ficção inicialmente sob a perspectiva de Dorothy. É plausível pensar que seria bastante difícil optar diretamente pela abertura do romance sob o ponto de vista de Solomon, muito embora sua perspectiva tenha relevância igual ou maior para o conjunto do romance. Como personagem, Solomon é bastante enigmático para Dorothy e o será, por algum tempo, para o leitor, mas a intuição, os pensamentos de Dorothy e sua atuação no primeiro segmento servirão como mediação importante para que se tenha curiosidade sobre o histórico, a vida pregressa de Solomon, curiosidade e interesse que serão contemplados no segundo segmento, já que nele se falará de sua vida na África, o envolvimento na guerra civil, a luta pela sobrevivência, o caminho doloroso até à Inglaterra e à cidadezinha no norte do país.

“A Inglaterra mudou” é frase seca e recorrente que ecoará ao longo dos dois primeiros 
segmentos e ampliará a questão, para abranger também as mudanças no mundo ocidental, ou ao menos na percepção de outras partes do mundo que o ocidente alcançou. Essa frase abre o romance e será repetida com um significado muito diverso e enriquecido de sentidos cerca de sessenta páginas adiante, próximo ao final do segmento. Este detalhe da composição do segmento exemplifica um recurso recorrente em muitas partes do romance: a utilização de enunciados habitualmente empregados de forma corriqueira na vida cotidiana, às vezes como clichês, formas banais de expressão que, articuladas ao desenrolar da narrativa, vão recebendo uma carga de significados pelas situações engendradas, perdem o automatismo quase vazio de comunicação banal e adquirem nova vitalidade. É marca do estilo de Caryl Phillips em seus romances.

No início do romance em foco, trata-se mesmo de um chavão que, fora dele, é usado inúmeras vezes por muitos europeus nostálgicos de um passado visto como sendo mais ordenado, mais humano e glorioso. É comum ouvir esse mesmo chavão da boca de certos turistas e visitantes estrangeiros à Inglaterra, ao expressarem certa decepção pela relativa perda do país de sua aura aristocrática, pela constatação de que, de fato, o império não existe mais e de que, finda a Segunda Guerra Mundial, ao longo dos anos a Grã-Bretanha se abriu, mais ou menos, dependendo do período histórico e das necessidades internas por mão-deobra, para receber, bem ou mal, um grande contingente de imigrantes das ex-colônias, exsúditos e membros da Commonwealth.

Sabe-se bem que não só a Inglaterra mudou, mas também outros países do Primeiro Mundo na Europa Ocidental, e que grande parte dessa mudança tem a ver com o adensamento nas metrópoles, a emigração de grandes contingentes populacionais e o acirramento do que se denominou de globalização, acompanhada da disseminação de xenofobia:

\footnotetext{
“[...]Vindas de países pobres, as correntes migratórias em busca de trabalho transformaram-se em grossas torrentes na medida em que conseguiram não ser estancadas por barreiras políticas. [...] Infelizmente, nas tristes décadas seguintes a 1970 e 1980, a imigração em busca de trabalho ficou cada vez mais difícil de se distinguir das correntes de homens, mulheres e crianças que fugiam ou eram desterritorializados devido à fome, à perseguição étnica ou política, à guerra e à guerra civil e assim confrontavam-se com os países do primeiro mundo, igualmente empenhados (em teoria) em ajudar os refugiados e (na prática) em impedir a imigração oriunda de países pobres, com graves problemas de casuística legal e política. Com a exceção dos Estados Unidos e, em menor grau, do Canadá e da Austrália, que encorajaram e permitiram a imigração em massa vinda do terceiro mundo, os países do Primeiro optaram por mantê-los longe de seu território sob a pressão de uma xenofobia crescente no meio de suas populações naturais." 9
}

9 Hobsbawm, Eric. The Age of Extremes. Londres: Abacus, 1994, pp. 363,364 (minha tradução). No original: "[...]From the poor countries the streams of labour migration into the rich swelled into huge torrents, insofar as 
No romance, à primeira vista as frases iniciais parecem conter um ranço xenófobo: “A Inglaterra mudou. Hoje em dia é difícil saber quem é da região e quem não é. Quem pertence ao lugar e quem é forasteiro. É inquietante. Não parece direito." ${ }^{10}$ (DS,3). No entanto, verificar-se-á que se trata apenas dos sentimentos de ingleses a respeito de seus conterrâneos, relativos a um preconceito de classe. Assim, Dorothy expressa-se por meio de um chavão que poderia ser interpretado como preconceituoso, mas isso será logo descartado. Já no primeiro parágrafo, revela-se que a questão é haver uma divisão na cidade: de um lado, o condomínio de casas recém-construído na parte alta da mesma, área que se denominou Stoneleigh, por acharem o nome mais sofisticado e para que se pudessem atrair novos moradores de poder aquisitivo pouco maior que o dos demais moradores da cidade de Weston, que, na verdade contém o condomínio de Stoneleigh, e cujos moradores muito se ressentiram da invasão de recém-chegados de classe média. Essa informação é transmitida ao leitor pelo relato que a personagem-narradora faz de uma detalhada conversa travada com o carteiro, em que este reclama da atitude dos moradores do condomínio de insistirem em utilizar "Stoneleigh" como nome da localidade nos endereços da correspondência quando, na verdade, oficialmente não existe esse lugar, pois é apenas uma invenção para engrandecerem a si mesmos e ao status do domicílio..

Prontamente, se observa o despojamento da linguagem e o tom fluido e simples empregado na narrativa em primeira pessoa mas, em poucos parágrafos, vê-se também a complexidade da visão de Dorothy, que é nova no lugar. Há o jargão das imobiliárias que inventam uma sub-área na cidade, constituída pelo "novo empreendimento", dando-lhe nome sofisticado; há os novos moradores que tentam incorporar esse status; há os velhos moradores que resistem em preservar o nome e a identidade da cidade; há o carteiro perplexo com o comportamento burguês dos novos moradores (“[...]se eles insistiam em viver na terra maluca do faz-de-conta, quem era ele para impedir?"11(DS,4))

they were not damned back by political barriers. [...] Unfortunately, in the grim 1970s and 1980s labour migration became increasingly hard to separate from the torrents of men, women and children who fled from, or were uprooted by, famine, political or ethnic prosecution, war and civil war, thus facing the countries of the First World, equally committed (in theory) to helping refugees and (in practice) to preventing immigration from poor countries, with severe problems of political and legal casuistry. With the exception of the USA, and to a lesser extent Canada and Australia, which encouraged or permitted mass immigration from the Third World, they opted to keep them out under the pressure of a growing xenophobia among their native populations."

10 Acima traduzido por mim. No original: "England has changed. These days it's difficult to tell who's from around here and who's not. Who belongs and who's a stranger. It's disturbing. It doesn't feel right."(DS,3)

11 Acima traduzido por mim. No original: "[...] if they wanted to live in cloud-cuckoo land, then who was he to stop them?" (DS,4) 
Logo se registrará que Weston é uma pequena cidade no norte da Inglaterra, a setenta e cinco milhas de distância da costa, cidade que é homônima de outras duas européias, fato que Dorothy não deixa de colocar na devida perspectiva: uma, na Alemanha, que havia sido totalmente bombardeada pela Força Aérea Britânica na Segunda Guerra e, a outra, na França, repleta de judeus que haviam sido expulsos para os campos de concentração. Porém, através da sensibilidade da narradora-personagem, cuja linguagem atua como um filtro aberto e claro, sem indiretas, coloca-se a cidade no devido lugar: [...]"Não posso evitar o sentimento de que Weston, por comparação com as duas, se mostre bastante acanhada. Aparentemente, a coisa mais importante que aconteceu por aqui foi o fechamento das minas de carvão pela Sra. Thatcher e isso, já há mais de vinte anos." (DS,4) $)^{12}$ Dorothy quer acentuar o passado prosaico do lugar se comparado às grandes lutas dramáticas por que passaram as cidades na época da Segunda Guerra.

A aparente displicência do comentário da personagem pode, por contraste, trazer ao leitor a oportunidade de se deter um pouco e de fazer conjeturas quanto ao estado de coisas na vida social nas cidades e no país em nossa época. Há mais de meio século desde a Segunda Guerra e com a perspectiva da carnificina que foi a Primeira Guerra e a possibilidade de destruição do planeta por meio das bombas atômicas, tomando-se relativa distância histórica do que esses acontecimentos significaram, espanta-se, embora pouco, a personagem, quanto à importância da localidade e, talvez o leitor reconheça a sensaboria, a pequenez da vida retomada em moldes provincianos no lugarejo, quase como se aqueles acontecimentos, que tanto marcaram a Europa e o mundo, não tivessem imprimido mudanças na recôndita Weston e na mentalidade dos habitantes. É pergunta sobre a qual se poderá refletir novamente no final do segmento.

De passagem e com ironia desvalorizadora, a personagem faz menção ao que, na verdade, deixou marca indelével na região de mineração e siderurgia no país como um todo. As greves do início dos anos oitenta, e especialmente a dos mineiros do norte da Inglaterra, foram uma luta em protesto contra o fechamento do ganha-pão de muitos pelo governo por razões econômicas. A NUM (National Union of Mineworkers), tradicional associação de mineiros que se originou em 1880 e sempre fora ativa na defesa dos direitos de seus membros foi alterada pela desagregação de um grupo de mineiros que quiseram voltar ao trabalho

12 Tradução acima feita por mim. No original: “[...] I can’t help feeling that it makes Weston seem a bit tame by comparison. Apparently, the biggest thing that had ever happened in Weston was Mrs. Thatcher closing the pits, and that was over twenty years ago." (DS, 4) 
durante a greve, o que resultou na formação da UDM (Union of Democratic Workers). Outra conseqüência foi a promulgação do Trade Unions Act em 1984, segundo o qual antes de haver uma greve, qualquer sindicato é obrigado a fazer votação secreta. ${ }^{13}$

De fato, concretamente a referência é feita à década de 1980 e ao governo de direita de Margaret Thatcher, "movido por uma forma extrema de egoísmo nos negócios e de laissezfaire", caracterizado por ser "profunda e visceralmente nacionalista e desconfiado do mundo exterior" - contradição básica bem assinalada pelo historiador atento. ${ }^{14}$ Foi uma época que também foi marcada por um grau maior de pauperização de segmentos da população: "No Reino Unido (1989) 400.000 pessoas foram oficialmente registradas sob a categoria de "semteto" (United Nations Human Development, 1992, p. 35). Quem, nos anos de 1950 ou mesmo no começo da década de 1970 , poderia ter imaginado isso?"15

Todas essas mudanças subjazem à frase de abertura do romance, "A Inglaterra mudou", e o leitor será guiado por Dorothy, mas saberá que Dorothy apresenta também uma visão marcada por pré-julgamentos. De qualquer forma, o romance apresenta a deterioração de várias instituições - principalmente as ligadas ao Bem-Estar Social, Welfare State, as de saúde (lembre-se das reformas drásticas por que passou o Serviço Nacional de Saúde (NHS) em 1988 e anos subseqüentes), de educação e do sistema prisional - e aspectos da vida na Inglaterra. A partir de meados dos anos de 1970 houve um declínio constante nas indústrias manufatureiras do norte do país, o que resultou em fábricas abandonadas, cidades em depressão econômica e alto desemprego. Ao mesmo tempo houve um aumento no número das indústrias de serviço no sul e também acréscimo no de firmas de alta tecnologia nas áreas de Londres e Cambridge. A crescente afluência do sul durante os anos de 1980 contrastava com os problemas nas cidades industriais do norte e da área central do país (Midlands), nas quais muitos dos jovens que terminavam o ensino médio não conseguiam emprego e grande número de trabalhadores eram demitidos. Havia também maior índice de criminalidade e padrão de vida geral inferior ao do sul. Esse desequilíbrio nas regiões do país ficou conhecido como a cisão norte-e-sul (North and South Divide) ${ }^{16}$. A diferença permanece até hoje e o romance

13 Room, Adrian (org.) Dictionary of Britain. Oxford: Oxford University Press, 1990, pp. 382 e 400.

14 Hobsbawm, Eric. The Age of Extremes. Londres: Abacus, 1994, p. 248. Acima traduzido por mim. No original: "...committed to an extreme form of business egoism and laissez-faire"; "profoundly nationalistic and suspicious of the outside world".

15 Idem. Ibidem, p. 406. Acima traduzido por mim. No original: "In the United Kingdom (1989) 400,000 people were classed as "homeless" (UN Human Development, 1992, p.31). Who, in the 1950s, or even the early 1970s, would have expected this?"

16 Lavery, Clare. "The North-South Divide". In: Focus on Britain Today. Londres: Macmillan, 1993, pp. 102, 103. Note-se que a existência dessa divisão vem desde o século XIX. 
problematiza a apresentação dessa condição através do registro do contraste entre a realidade e as expectativas diversas, tanto as de uma pessoa natural do país (Dorothy) quanto as de outras que ali chegam em busca de refúgio (Solomon, oriundo da África, e Said, do Oriente Médio). Pelos demais segmentos, será necessário pensar sobre a articulação de Ocidente e Oriente, crucial no romance.

Considerado no total dos cinco segmentos que o compõem, A Distant Shore mostra uma relativa abertura para abarcar diversos espaços do país, sempre abordados de forma problematizada sob várias perspectivas, como se mencionou. No primeiro segmento, há a visão do interior, das pequenas e médias cidades da região mais empobrecida do país, o Norte. É válido lembrar que o próprio primeiro-ministro, Tony Blair, em promessas na última campanha para a reeleição em 2005, referiu-se à necessidade de se revitalizar economicamente "as esquecidas cidades do Norte" ("the forgotten cities of the North").

A cidade natal de Dorothy, onde os pais estão enterrados, situada no norte, é descrita como "barulhenta e imunda" (DS,29) e Dorothy não entende como conseguiu viver ali. Weston é periférica em relação a ela e Stoneleigh, um condomínio pouco mais próspero dentro de Weston. Face a Stoneleigh, os tradicionais moradores de Weston sentem-se vítimas de uma invasão de arrivistas, sentem que "as suas vidas restritas", já anteriormente marcadas pelos fechamentos das minas e das siderúrgicas e pelo desemprego, "tornavam-se ainda menos importantes do que haviam imaginado até então"17 (DS,29).

O segundo segmento se passa na capital do país, que é vislumbrada como metrópole infernal e vista, na maior parte do tempo, de dentro de uma prisão: não propriamente como lugar para uma pessoa se estabelecer, mas como ponto de partida para uma fuga. O terceiro segmento transcorre em Londres, mas em um bairro mais modesto ao sul do rio Tâmisa e representa aspectos sociais da vida dos ingleses. O quarto, retrata um itinerário que parte de Londres, vai até ao norte, e está menos definido como espaço externo e mais como passagem em busca de refúgio.

Retomando-se a frase de abertura, "A Inglaterra mudou”, será possível observar como ressoa com ironia sobre muitas práticas sociais da vida contemporânea, representada ao longo dos segmentos. É instigante e irônico o fato de a protagonista e narradora do primeiro segmento ser justamente uma inglesa de classe média, de 55 anos, ex-professora de música no ensino médio, nascida de pais pertencentes à classe operária, educada em uma universidade,

17 Trechos acima traduzidos por mim. No original: "noisy, filthy town"; "their shrinking lives"; [...] "were even less important than they had hitherto imagined." (DS,29) 
divorciada de um homem de negócios e forçada a se aposentar precocemente. Instigante e irônico porque Dorothy a um só tempo incorpora muito dos estereótipos geralmente atribuídos ao inglês de classe média, visto como possuidor de auto-disciplina, organização, confiança tácita nas instituições e na sociedade, cumpridor dos deveres mas defensor do lema "viva e deixe viver", pessoa de boas maneiras e de civilidade e cioso de sua liberdade e privacidade. Enfim, Dorothy é alguém que cresceu e se tornou adulta não mais no império, mas ainda assim numa fase próspera e ascendente que surgira no país após a Segunda Guerra Mundial. Hobsbawm registra o seguinte:

\footnotetext{
"Em termos da utilização humana real de sua riqueza e potencial produtivo, o povo britânico desfrutava das vantagens das economias mais avançadas: melhor saúde, maior nível de vida e melhor educação. Poucos povos tinham melhor alimentação ou habitação. [...] Existia "pobreza", mas com significado diferente do que se dava a essa palavra na maior parte do mundo, ou seja, fome e farrapos. Graças a um sistema de segurança social, a Grã-Bretanha não apresentava mais aqueles bolsões de miséria e quase penúria que ainda desfiguravam tão dramaticamente os Estados Unidos."18
}

Há uma convivência de forças relativamente opostas nessa personagem de meia-idade: carrega aspectos fortes da estereotipia atribuída aos ingleses e seus valores e tradições, mas é testemunha da experiência do que se chamou, na época, de "revolução cultural" nos costumes, na família, na posição da mulher na sociedade, época que também pode ser entendida como "o triunfo do indivíduo sobre a sociedade, ou melhor, como a ruptura dos fios que, no passado uniam os seres humanos em tessituras sociais" ${ }^{19}$. Note-se que, politicamente, a primeiraministra Margaret Thatcher dava expressão a outras mudanças com a afirmação de "não haver sociedade, apenas indivíduos"20. De qualquer forma, o tempo dominante da enunciação da narrativa em todos os segmentos é o presente deste início de terceiro milênio e está marcado como fase posterior a essas transformações na sociedade e na personagem. Sublinhe-se, porém, o conservadorismo, que é tônica bastante forte na formação da vida social na Inglaterra. $^{21}$

Deve-se notar a forma irônica como o romance $A$ Distant Shore coloca essas idéias em perspectiva: a narrativa de fato apresenta dois indivíduos bastante despregados da sociedade, em busca de refúgio no interior do país. São indivíduos que têm muitas diferenças, mas em

18 Hobsbawm, Eric. Da Revolução Industrial Inglesa ao Imperialismo. Rio de Janeiro: Editora Forense Universitária, $5^{\text {a }}$ edição brasileira , 2000. Tradução de Donaldson Garschagen do original Industry and Empire, de 1968. p. 296.

19 Hobsbawm, Eric. The Age of Extremes. Londres: Abacus, 1994, p. 334.

20 Ibidem, p. 337.

21 Nairn, Tom. “The English Literary Intelligentsia”. In: Bananas Literary Supplement. 1971. 
comum o fato de poderem ser considerados socialmente supérfluos, porém em luta para buscar ou manter um lugar social seu. Veja-se que se trata de uma mulher de meia-idade aposentada, no presente quase sem profissão (apenas uma aluna particular no condomínio) e sem família, e de um imigrante que entra no país ilegalmente e, por sorte, consegue papéis e a função de zelador e guarda-noturno nesse mesmo condomínio, que é área periférica, um quase "não-lugar", em relação às cidades. Mais irônico e rico ainda é o fato de essa inglesa conservadora se sentir protegida por um forasteiro vindo da África, e, saber-se-á adiante, tratar-se de um homem perseguido por lembranças traumáticas, que vive isolado e ignorado nas comunidades em que transita, seja a do pequeno condomínio de Stoneleigh, seja a dos velhos moradores de Weston.

A perspectiva da narrativa em primeira pessoa, o ponto de vista de Dorothy exerce uma função unificadora neste primeiro segmento, que se ampliará também em outras partes do romance. O leitor da obra de Caryl Phillips está muitíssimo acostumado com os deslocamentos de planos narrativos, com a quebra da ordem cronológica, com a alternância de perspectivas que surgem inesperadamente e, como resultado dessas características, com uma ironia constitutiva, sempre parte integrante dela. Nos seus romances de cunho histórico mais acentuado, especialmente na trilogia formada por Cambridge, Crossing the River e The Nature of Blood, tudo isso tem impacto redobrado e força espetacular porque se sobrepõem camadas de sentido dependentes do reconhecimento da experiência histórica vista em retrospecto $^{22}$. A Distant Shore compartilha de muitos desses elementos em sua composição, mas difere bastante quanto à tonalidade que dela resulta. Está muito aquém dos romances da trilogia no quesito do impacto vigoroso, na impressão forte que causam, sempre mantendo a qualidade, e se coloca mais próximo do tom menor e de tristeza que recobre também um de seus primeiros romances, The Final Passage, no qual se relata a história de um jovem casal emigrado para Londres de uma pequenina ilha do Caribe na primeira década logo após a Segunda Guerra. De comum entre os dois romances há a proximidade da matéria narrada com o tempo como matéria de ficção: The Final Passage se passa em 1948 e A Distant Shore na primeira década dos anos 2000, havendo entre as duas marcas temporais quase meio século de lutas por integração racial, parte da temática de ambos. São como momentos importantes no continuum da história das relações raciais na Grã-Bretanha, que merecem atenção. Houve o momento no pós-guerra da forte campanha de abertura para a imigração, promovida pelo

22 Estudei esse aspecto e a criação de linguagens presentes em Crossing the River na dissertação de mestrado intitulada "Trilhas pela Água: Crossing the River de Caryl Phillips", defendida em fevereiro de 2003. 
governo britânico para compensar a falta de mão de obra em várias indústrias e instituições públicas. Houve o momento dos distúrbios raciais de Notting Hill em 1958 em Londres, distúrbios seguidos por um período de quase cinqüenta anos em que se aprovou variada legislação visando não apenas ao controle dos fluxos imigratórios, mas até a uma espécie de "repatriação induzida"23 em 1978. Houve o recrudescimento da política racista de direita, representada por figuras como Enoch Powell e Margaret Thatcher. Houve mais distúrbios civis em Toxteth, em Handsworth, em Moss Side; os episódios em Brixton, provocados pela violência policial praticada contra Cherry Groce (1981) em sua própria casa e os episódios em Bridwater Farm (1985), provocados pela morte de Cynthia Jarret. ${ }^{24}$

À guisa de comentário, note-se que esse meio século de lutas pela integração ou melhor convivência entre as raças na Inglaterra equivale aproximadamente aos anos de vida do autor. Ele mesmo confirmou haver se utilizado de dados de sua experiência biográfica e familiar, não só da história direta de seus pais, mas a de tios e tias vindos do Caribe, para a feitura de The Final Passage ${ }^{25}$. Sem dúvida o seu desenvolvimento como homem e como escritor se deu em meio a essas mudanças na vida social da Grã-Bretanha. Em entrevista ${ }^{26}$ sobre esse romance, que foi também base para o roteiro de filme do mesmo nome, de autoria do próprio Caryl Phillips e de Peter Hall, o autor diz:

"O livro foi escrito no espírito, creio eu, de generosidade, em homenagem à geração de meus pais, numa tentativa de resgatar a importante contribuição que deram e que estava sendo negada, solapada, banalizada por alguns políticos. A emigração das antigas ex-colônias do império transformaram a Grã-Bretanha nos últimos cinqüenta anos. A emigração caribenha causou um impacto fenomenal.

$$
\text { (...) }
$$

São avassaladoras e inegáveis as provas das mudanças enormes na sociedade britânica. Não há time importante de futebol neste país que não tenha em seu time algum descendente das pessoas que desceram daqueles navios. Não há indústria de relevância - os correios, as telecomunicações, os transportes ferroviários, o sistema de saúde - que não tenha em seus quadros os filhos daqueles que emigraram. Mas as pessoas desconhecem as suas origens. Não compreendem porque tudo remonta àquela época nos anos de 1950."27

23 Termo usado por A. Sivanandan, citado por Kwesi Owusu na introdução de Black British Culture and Society, Londres e Nova Yorque: Routledge, 2000, p.2 e também em "The Struggle for a Radical Black Political Culture -- An interview with A. Sivanandan", pp. 416-424 na mesma antologia.

24 Owusu, Kwesi (org). Black British Culture and Society. Londres e Nova Yorque: Routledge, 2000 , p.6 e p.11. 25 Phillips, Caryl. The Final Passage. Londres: Faber \& Faber, 1985.

26 Jaggi, Maia. "The Final Passage: an interview with Caryl Phillips". In: Owusu, Kwesi. Black British Culture and Society, op. cit., pp.157-168. O filme foi lançado em julho de 1996.

27 Tradução minha do original, p.157, p. 159: “The book was written in a spirit of, I hope, generosity, paying tribute to my parents' generation and trying to recapture the major contribution that was being denied by certain politicians - undermined, trivialized. Migration from former colonies has transformed Britain in the past fifty years. Caribbean migration has made a phenomenal impact (...)The evidence of sea changes in British society is becoming overwhelming and undeniable. There's no major football team in this country that doesn't have a 
Passados quase cinqüenta anos desde que os famosos navios Ormond e Windrush primeiro aportaram na Grã-Bretanha em 1947 e 1948 respectivamente, trazendo 592 trabalhadores do Caribe, seguidos por muitos mais -- sendo que $36 \%$ da primeira geração de caribenhos emigrados havia desembarcado antes do final da década de $1950^{28}$--, sabe-se que particularmente nas últimas duas décadas do século XX a nação recebeu grande número de emigrantes e refugiados que entraram legal ou ilegalmente, vindos de vários países do leste europeu, do Oriente Médio e da África. Em A Distant Shore há referências a personagens vindas da África (Gabriel/Solomon), do Iraque (Said) e do Punjab (Mahmood): a primeiro fugida das perseguições da guerra, as duas últimas em busca de trabalho e melhores condições de vida.

É interessante que o autor tenha escolhido como personagem-narradora uma inglesa quase da mesma idade da sua própria, uma pessoa de meia-idade que desenvolveu uma consciência crítica do mundo, alguém que vê as coisas sob um ângulo menos ilusório e que, principalmente, procura expressar-se sem rodeios e subterfúgios, sem abrandar os problemas. Tanto o primeiro quanto o terceiro segmento, referentes a Dorothy, apresentam a experiência difícil que é viver no século XX: desde as relações sociais descaracterizadas e desumanizadas - lembrem-se das instâncias de "micro-despotismos" no quotidiano, no trabalho, no lazer e no consumo $^{29}$--, até as situações mais dramáticas, seja a perda dos familiares, o assassinato de um amigo, o descontrole emocional por depressão e relativa perda da razão. É através de uma linguagem de aparência despojada, muitas vezes em tom de conversa despretensiosa, de grande limpidez que o primeiro segmento é apresentado ao leitor.

“A Inglaterra mudou" nos diz Dorothy no início e no final do segmento em que se apresenta o seu primeiro relato. A narrativa entre os dois enunciados flui solta, desliza sem solavancos, graças a certos recursos como a manutenção da sintaxe tradicional, do uso de um léxico compreensível e descomplicado sem chegar a ser de todo coloquial, do raciocínio claro e perspicaz - características inegáveis da narradora-personagem e da linguagem que é expressão de seu pensamento atento a tudo. Por todo o segmento há detalhes que emergem sempre para apontar para significados mais relevantes. A menção de atitudes comuns, como

player who's a descendant of the people who stepped off those boats. There's no major industry - the Post Office, British Telecom, British Rail, the health system - that's not staffed by their children. But people don't know their origins. They don't understand because it goes back to that moment in the 1950s."

28 Ver referências aos estudos de T. Jones, James, W. e Harris, C. na nota nº em Owusu, K. op.cit., p.13.

29 Santos, Boaventura de Sousa. Pela Mão de Alice: O Social e o Político na Pós-Modernidade. São Paulo: Editora Cortez, 1997, p.109. E ver também Foucault, Michel. Microfisica do Poder. Rio de Janeiro: Graal , 1998. 
colocar um anúncio no jornal oferecendo aulas particulares, como observar que alguém lava o próprio carro à vista de todos e que um jardineiro de cemitério se empenha com alegria em seu trabalho, surge para formar uma rede de índices que convidam o leitor à reflexão. Por trás dessas situações estão questões importantes como a desorientação de uma pessoa que se vê aposentada e não sabe bem o que fazer do tempo que era destinado ao trabalho, como o desconhecimento de um estrangeiro das práticas e costumes no novo país e a capacidade de uns poucos de manterem um vínculo não-alienado com um trabalho que poderia ser considerado menor.

Adentramos o enredo pela perspectiva de Dorothy e a leveza e fluidez da narrativa desse primeiro segmento traçam um percurso que parece um passeio: pelo novo condomínio, Stoneleigh, pela área velha de Weston, pelas idas ao médico em uma cidade vizinha, pelas visitas ao cemitério nessa cidade vizinha onde estão enterrados os pais, por uma pequena viagem ao litoral, não distante dali. As andanças de Dorothy por esses espaços e o desenrolar de seu pensamento ocorrem simultaneamente e desenvolvem a narrativa caracterizada pelo peso do tempo da enunciação, o presente como horizonte estruturante, pinçado a intervalos curtos e freqüentes por outros planos narrativos, planos da memória e da reflexão. É como se num rio extenso, representado pelo presente da personagem a fluir lentamente, obrigada que está a fazer um balanço de sua experiência, houvesse muitos afluentes, momentos, relações e influências importantes em sua vida. A simplicidade e clareza da linguagem, face aparente da narração, se articulam com o entrelaçamento de variadas incursões no passado, pinçadas com freqüência e trazidas ao primeiro plano, de forma a criar um tecido de urdidura bastante intrincada. A aparência inicial de fragmentos do passado vai se compondo até se recolocarem os pedaços num mosaico que contém a vida de Dorothy, com as imbricações de classe e gênero, a vida num lugarejo de um país avançado no ocidente no início dos anos 2000.

É útil ver como se estrutura o enredo. Em seguida aos três primeiros parágrafos, que mostram um rápido panorama das mentalidades numa região do país, informa-se, sucintamente, o fato de Dorothy ter-se aposentado precocemente, fato que aparece imediatamente relacionado a outra mudança importante no sistema educacional da Inglaterra, o que vem acompanhado da opinião de Dorothy e do que ela relata como a opinião de seu pai.

Está registrada a mudança no sistema educacional: a eliminação das tradicionais grammar schools, o ensino voltado inteiramente à formação acadêmica, e dos exames chamados de eleven plus, a que as crianças se submetiam com onze anos de idade, cujo 
resultado decidiria o seu futuro de vida - quer dizer, ou a criança iria cursar a chamada grammar school, que a levaria à universidade e à vida acadêmica ou à carreira política, ou iria para uma secondary modern e para uma escola técnica ${ }^{30}$. Pouco antes do ano 2000, praticamente se abolira esse sistema, substituído pelo que se denominou Comprehensive Schools, escolas que englobariam as características das instituições acadêmicas elitistas, as das meio-termo chamadas Secondary Modern e as das escolas técnicas. A narrativa traz ao primeiro plano uma fala do pai relembrada por Dorothy, que sintetizava a visão certeira da classe operária sobre as antigas escolas. Porém, a necessária e esperada democratização do sistema, com a abolição das Grammar Schools, não parece ter tido sucesso, tampouco revitalizado a vida da professora:

\begin{abstract}
"Em maio me aposentei como professora. Há quatro anos a escola passou a ser escola generalista, e, desde então o nível despencou. Me deixou em uma situação um pouco difícil porque passei a vida inteira batendo a tecla de que seria melhor se os adolescentes de todas as classes sociais e de todos as origens estudassem juntos e aprendessem uns com os outros. É nisso que meu pai acreditava. Detestava ver os meninos das escolas de elite usando as camisas brancas, as gravatas e os paletós chiques, enquanto os meninos das escolas generalistas mal conseguiam achar um par de meias que combinassem. Lembro bem da forma como ele desaprovava e sacudia a cabeça: "Guerra de classes, querida" dizia ele. "Guerra de classes antes mesmo de eles deixarem de usar calças curtas”. Mas então há quatro anos as delegacias de ensino eliminaram as escolas elitistas, a nossa escola virou generalista e eu fui colocada à prova. De repente tinha que ensinar qualquer um que entrasse na escola - todos nós tivemos que fazer isso. Não faço objeção aos adolescentes difíceis, mas ponho um limite quando se trata de vândalos. Depois, veio a aposentadoria antecipada e me salvou. E quando vi o anúncio do condomínio em Stoneleigh no jornal, pensei comigo, por que não, uma mudança vale tanto quanto um bom descanso." 31 (DS,5)
\end{abstract}

De passagem, note-se que o parágrafo se fecha com um provérbio característico da língua e da mentalidade inglesas. É sabido que os provérbios exemplificam um imobilismo, a petrificação de experiências vividas por muitas gerações, uma espécie de fecho que conclui uma conversa e que não supõe que se retruque, pois são algo como uma sentença ou veredito.

No caso em questão, o conteúdo do provérbio tem uma natureza leve e positiva: "uma

30 Room, Adrian. Dictionary of Britain. Oxford: Oxford University Press, 1990, p. 33.

31 Tradução acima por mim. No original: "In May I retired as a school teacher. Four years ago the school went comprehensive and since then standards have plummeted. It left me in a bit of a spot as I've spent most of my life banging on about how it would be better if kids of all levels and backgrounds could be educated together and learn from each other. It's what Dad believed. He hated seeing the grammar-school boys in their white shirts and ties, and their flash blazers, while the kids from the secondary modern could barely find a pair of socks that matched. I can still see him shaking his head and pointing. 'Class war, love,' he'd say. 'Class war before they're even out of short pants.' And then four years ago, the education authority scrapped grammar schools, turned us comprehensive, and they put me to the test. I was suddenly asked to teach whoever came into the school - we all were. Difficult kids I don't mind, but I draw the line at yobs. But then early retirement came along to save me, and when I saw the Stoneleigh advert in the paper I thought, why not, a change is as good as a rest. [...]" (DS,5). 
mudança equivale a um bom descanso" é frase utilizada para se apregoar a variedade de atividades como forma de renovação de energias. Imagina-se, por exemplo, a mãe de um adolescente que o estimula a ir jogar futebol ao invés de dormir durante a tarde depois de ter estudado muito. O provérbio se aplica quando há o controle da situação: o sujeito pode desfrutar de uma boa forma de descanso se optar por uma atividade diferente. Ora, parecerá ao leitor que Dorothy vem morar em Stoneleigh quase que somente para se beneficiar da "mudança de ares" e para desfrutar desse descanso que parece buscar. Na verdade, busca refúgio - e note-se a etimologia da palavra, vinda do latim, que leva à fuga --, mas o que motiva esse objetivo é uma carga de experiências bem pesada, nada tendo a ver com o leve saltitar de uma atividade a outra. Essa maneira de lidar com a linguagem e com a realidade é característica da personagem e da narrativa que ela articula e é fator essencial na composição intrincada da totalidade do romance.

Em outras partes do segmento notar-se-á que a narrativa é posta em suspenso - não são dados seguimento, detalhes, causa e razões para situações que são cruciais na vida da personagem. Termina-se a leitura do segmento sem se saber ao certo por que a morte de sua irmã Sheila pesa tanto para Dorothy, por que a relação de Sheila com os pais era tão insatisfatória, por que o casamento de Dorothy naufragou, por que Dorothy aceitou a aposentadoria antecipada, por que exatamente Dorothy sofre de depressão e por que sua vida parece estar à deriva. Esses hiatos e essa suspensão de informações são logicamente compatíveis com o discurso narrativo feito em primeira pessoa: a personagem conhece bem os fatores que formam o enredo de sua vida pregressa, e por bem conhecê-los prefere não se aprofundar neles ou no detalhamento das situações, mas o leitor acompanha a situação resultante e percebe a atmosfera. Porém, a narrativa, sendo conduzida pela personagem como narradora, acaba por deixar vislumbrar a conjuntura resultante desses fatores omitidos do passado no presente, pois a enunciação se move lentamente, desferem-se aqui e acolá comentários perspicazes e implacáveis sobre os outros, atitude atrelada à impaciência que a personagem tem para com o estado de coisas que a rodeia e para com a forma como se relacionam as pessoas à sua volta.

De volta ao trecho citado acima, vê-se uma realidade bem difícil, que é a rigidez da sociedade dividida em classes, captada aqui pela menção ao sistema educacional, a polêmica sobre a queda dramática da qualidade do ensino, a posição de uma professora que deixou de ser jovem há tempo, a sua constatação de que a realidade das mudanças do sistema trouxe 
problemas inesperados que a pegaram despreparada, juntamente com a decepção em que se transformou o governo do país - tudo o que Dorothy teve que enfrentar. Só no terceiro segmento é que se vai saber de outras dificuldades de sua vida, que também forçaram-na a aceitar a aposentadoria precoce. E então, "uma mudança vale tanto quanto um bom descanso", provérbio que poderia normalmente soar como positivo e confiante, adquirirá um caráter bastante irônico. As mudanças na vida de Dorothy pesaram bastante e a mudança de domicílio foi uma última tentativa de renovar alguma esperança e de se manter com controle.

A condensação que a narrativa apresenta impressiona. Em uma dezena de páginas descreveram-se Stoneleigh e Weston, alguns problemas urbanos da área, outros relativos a moradia e à educação. No plano principal da enunciação, o movimento de sustentação da narrativa foi simples: Dorothy chegou à casa nova, caminhou até o bar na parte velha da cidade, viu os jovens do lado de fora, conversou com o dono do bar, tomou uma bebida e subiu de volta ao condomínio. Nesse breve percurso, preenche-se melhor o panorama inicial: no presente, os moradores parecem hostis (“As pessoas me olhavam como se eu tivesse a marca de Caim na testa")(DS,6), há muita pasmaceira (“[...] logo ficou claro que a principal atividade nessas bandas era levar o cachorro para passear")(DS,6), os jovens não encantam ninguém e têm um jeito largado e não amigável (“'Malditos vândalos' é como o dono do bar os chama")(DS,7). Enquanto caminha até a casa, Dorothy se lembra do passado, dos pais falecidos, da irmã, do relacionamento dos quatro, das incompreensões entre o pai e a irmã mais nova e da forma como ela própria conseguia manter seus interesses e seguir o seu caminho sem se desviar ou se deixar atrapalhar, apesar da percepção de que era ela também o elemento de equilíbrio no ambiente que logo abandona para estudar na Universidade de Manchester, na mesma região do país. Antes de entrar na casa, olha a cidade abaixo e pensa nos problemas que a afligem, como o número de pedintes e de desabrigados que perambulam pelas ruas. Dorothy demonstra irritação pelo fato de essas pessoas terem parado de lutar pela própria vida e esse sentimento pode nos fazer lembrar o comentário de Adorno sobre Eichendorff, no qual diz que "[...]os inimigos dessa sociedade são representados pelos errantes, pelos apátridas de então, presságios do futuro daqueles que, como quer a filosofia em Novalis, estão em casa em qualquer lugar." ${ }^{, 32}$ Dorothy volta a se lembrar do pai e do que ele pensaria sobre a degradação da cidade e sobre único bar da redondeza:

32 Adorno, Theodor W. "Em memória de Eichendorff” In : Notas de Literatura I. São Paulo: Livraria Duas Cidades/ Editora 34, 2003, (tradução de Jorge de Almeida) p. 101. 


\begin{abstract}
"Meu pai teria gostado do Waterman's Arms, tinha certeza, pois ele via os bares como lugar de refúgio. Costumava dizer que os bares deviam ser como santuários em que a pessoa pode ser o que é sem ter que tomar cuidado com os modos, mas por isso mesmo é que a pessoa tinha que achar um bar que se adequasse a si. Os bares eram todos diferentes uns dos outros, como as pessoas, e enquanto algumas fazem você mostrar o melhor de si e fazem você se abrir, outros nos fecham, nos calam e a gente então só quer sentar num canto e tomar conta da bebida.[...] Insistia que os bares tinham a ver com a possibilidade de sermos quem de fato somos e ressaltava a necessidade de se procurar sempre até se achar um em que você se sentisse à vontade. Porém, nunca me disse o que fazer se eu acabasse por morar numa cidade com apenas um bar. Acho que nenhum de nós pensou que uma coisa dessas pudesse acontecer." (DS,13) ${ }^{33}$
\end{abstract}

Nesse início de segmento continua a dominar o fluir lento e calmo e a impressão de uma vida sob controle em que exteriormente as coisas transcorrem sem muitos percalços, aparentemente não muito diferente do ritmo interno da memória e da sensibilidade aguda com que a matéria é lembrada. Tudo condiz com o manto com que se recobrem as situações, a forma como a personagem-narradora atenua, silencia ou oculta dados da sua realidade. Não se pode esquecer da frase inicial sobre a mudança no país: o pequeno parágrafo acima citado descreve o bar inglês em pinceladas como uma instituição tradicional, mas denota ainda mais a situação de Dorothy, como uma inglesa que tenta se encontrar em seu próprio país, que acredita encontrar refúgio nesse bar, mas que antevê a dificuldade. Logo avulta uma pergunta: como será possível encontrar refúgio numa situação tão restrita? A evolução da fábula confirmará o engano e mostrará a impossibilidade da busca.

A ironia quase sardônica se revela somente na releitura do segmento: tudo o que parecera adequado, correto, fluido e calmo logo vai desmoronar. Dorothy vai demorar três meses para voltar ao bar, período em que não cria qualquer laço, apenas se depara com as pessoas em todos os lugares contra a vontade e essas são vistas como estranhos, títeres perdidos, como “[...] o elenco da cidade, cada qual desempenhando o papel que lhe coube. Mas nós de Stoneleigh, o pequeno grupo de extras que mora no topo da colina, ainda não recebemos os nossos papéis. Somos estranhos uns aos outros e ainda mais em relação aos velhos moradores da cidade.”(DS, 14$)^{34}$ A pessoa que se destaca é o vizinho que mora na casa

33 No original: "Dad would have liked The Waterman's Arms, that much I was sure of, for he regarded pubs as a place of refuge. He always used to say that they should be a sanctuary where you can be yourself and not have to watch your p's and q's, but this being the case you had to find a pub that fitted you. He'd remind me that they're all different, like people, and while some bring out the good in you and open you up, others close you down and make you quiet so that you just want to sit in the corner and nurse a pint.(...)He'd insist that they're about being yourself, and he'd stress that you had to keep looking around until you found a pub that you felt comfortable in. However, he never told me what to do if I found myself living in a place that only had the one pub. I don't think either of us ever imagined that anything like this could ever happen." (SD,13)

34 No original: "[.. ] the cast of the village, acting out their assigned roles. Those of us from Stoneleigh, the small group of extras who live up the hill, have yet to be given our parts. We're still strangers to each other, let alone to the other villagers."'(SD,14) 
ao lado, "um negro um pouco desnutrido, o zelador que faz-tudo e é também guarda-noturno do condomínio" (DS,14), Solomon, que, como ela, é uma pessoa solitária que se mantém no seu canto, com uma rotina férrea. É a primeira pessoa vista por Dorothy como tendo algo de bom. Interessante é que o que admira nesse imigrante são qualidades tidas como típicas dos europeus, e dos ingleses em particular: o cuidado e a precisão, o zelo com o carro e consigo próprio. Até então, em todos os lugares mencionados nessas quinze páginas iniciais, com exceção da breve referência ao carteiro, o que o leitor depreende são as figuras desagradáveis de delinqüentes, de mexeriqueiros, de interioranos fechados e hostis, de moradores de rua abandonados e sem perspectiva. Já Solomon é bem diferente: destaca-se pela aparente autosuficiência e isolamento.

$\mathrm{Na}$ fábula apresentada no romance, intercalado entre a caracterização inicial da figura de Solomon e os elogios à sua habilidade de dirigir, partindo da menção do fato de Dorothy estar quase pronta para ser levada de carro ao hospital, há um pequeno trecho do tipo sumário narrativo no qual Dorothy relata ligeiramente como o seu clínico geral recomendara que passasse a ser tratada por um psicólogo logo após a morte da irmã. Como se vê, são fatos importantes e pesados, pinçados repentinamente e sem ênfase, alçados ao presente da narrativa que segue seu ritmo fluido, como se esses acontecimentos não se distinguissem muito do fluir dos afazeres corriqueiros: aprontar-se, ir a uma consulta médica, almoçar, etc.. Britanicamente, a narradora não faz alarde das dificuldades, parece colocar tudo num nível de força aplacado, mas os entremeios em que se revelam a agudeza da sua percepção, os comentários certeiros, o julgamento afiado da personagem, dão ao leitor uma indicação da existência de problemas e camadas profundas - em nada passíveis de solução através de uma simples "mudança de ares". Assim, sutilmente, começam a se somar registros de experiências negativas: a morte dos pais, o divórcio, a morte da irmã, a aceitação de uma aposentadoria prematura, a mudança de casa e de cidade. Como já apontado, esmiuçam-se essas situações, os índices referentes a eles se apresentam salpicados pelo primeiro segmento e são retomados de forma semelhante no terceiro. Os dados são simplesmente enfileirados numa fala em que, superficialmente, o médico resume a condição em que Dorothy se encontra, "pressão demais para qualquer um suportar em tão pouco tempo" (DS,18), e declara a necessidade de ela começar a planejar uma nova vida. É um pequeno trecho regido por grande simplicidade e despojamento, mas se desdobra em muitos níveis de significação, como ocorre em outras partes do romance. Retrata-se apenas uma consulta médica, mas o embate entre as posições 
que os interlocutores assumem e a dificuldade de se comunicarem bem, o peso que a situação exerce sobre cada um, estão concatenados com muita propriedade pelo autor. A relação paciente-médico vai desembocar num corte na narrativa, corte provocado pela exortação ao planejamento de uma nova vida, tomada pela personagem como uma espécie de xeque-mate. “É preciso planejar a vida". Ora, o que dizer depois disso? Nem a personagem esboça qualquer observação, nem a voz narrativa cria qualquer imagem correlata que sirva de comentário. Há uma suspensão da cena, pura e simplesmente. A narrativa prosseguirá com o relato das ações rotineiras que normalmente sucedem à consulta, fora do hospital: Dorothy e Solomon almoçam em um restaurante próximo onde se serve comida somali e mediterrânea.

Conforme o texto:

"Tenho aqui o resultado dos seus exames e parece que tudo está bem com a senhora." Encarame diretamente e tenta colocar no rosto aquele sorrizinho bobo que todos eles têm." (DS,17)

O psicólogo conduz a consulta com muito cuidado, procurando estabelecer contato, mas Dorothy se mantém quieta. O médico reage e ela se vinga:

“--Aposentar-se precocemente pode ser um problema, mas a senhora ainda dá aulas de música, não é? De piano? Particulares?..."

Por que ele me faz todas essas perguntas? Foi idéia dele mesmo que eu me anunciasse dessa forma vulgar. 'Mulher desesperada oferece aulas de música'.

-- Estou tentando falar com a senhora, sra. Jones. Ficar parada olhando a parede não vai ser de ajuda a nenhum de nós, não é mesmo?

Olho para o seu rosto rechonchudo e decido que é chegada a hora de eu lhe retribuir o sorrizinho cretino.

-- A morte dos seus pais e o seu divórcio, a morte da sua irmã, a aposentadoria antecipada e a mudança de domicílio, é pressão demais para qualquer pessoa num período curto de tempo.

Ele pára para me dar a oportunidade de comentar, mas eu não tenho nada mais a dizer a ele.

--Você tem que começar a planejar uma nova vida, Dorothy. Sua irmã se foi, mas você ainda é relativamente jovem e não há nada errado com você fisicamente. Ainda há um bom tempo de vida no seu horizonte e você tem que começar a planejar, lutar e aproveitá-lo. Estou sendo claro?

Solomon e eu costumamos almoçar juntos na cidade antes de voltarmos a Stoneleigh.[...]"35

A ausência de comentário ou reação à observação feita pelo médico, o salto para a

35 Acima traduzido por mim. No original: "I have your results, Miss Jones, and everything seems fine." He looks me full in the face and he tries to put on that stupid little doctor smile that they all have.

"Early retirement can be a problem, but you're still teaching music, aren't you? The piano, I mean, privately."

Why is he asking me this? It was his idea that I advertise myself in that vulgar way. Desperate woman available for music lessons.

"I'm trying to talk to you, Miss Jones. Staring at the wall isn't going to help either of us now, is it?"

I look at his chubby face and decide that it's my turn to give him the stupid smile.

"The death of your parents, your divorce, the death of your sister, early retirement, and then moving home, that's a lot of pressure for anybody to have to deal with in a short space of time." He pauses to give me an opportunity to comment, but I have nothing further to say to him. "You have to start planning a new life, Dorothy. Your sister has gone, but you're still a relatively young woman, and there's nothing wrong with you physically. You've still got a significant spanse of life ahead of you, and you must start to plan and reach out and take it. Am I making myself clear?"

Solomon and I usually have lunch in town before going back to Stoneleigh. [...]” (DS, 17,18) 
descrição das atividades corriqueiras da vida servem um propósito. O encontro de Dorothy com o médico é uma entre muitas outras passagens do romance em que se evidencia a forma hábil pela qual se apresenta uma cena carregada de forte realismo e de verossimilhança com inúmeras situações de vida por que se passa no mundo do capitalismo pós-industrial, em que as relações inter-pessoais se mostram tão desgastadas que há uma generalizada má-vontade de uns para com os outros. Assim, uma questão fundamental, que é planejar o futuro de uma vida bem danificada, fica pairando no ar e se retoma o relato das atividades quotidianas.

No entanto, o corte na narrativa e a não-abordagem da questão proposta pelo médico voltarão à tona de forma revigorada. O feitiço vira contra o feiticeiro, o que foi recalcado volta a galope, bem antes do que imagina a personagem. A sofisticação de Dorothy em silenciar as feridas será involuntariamente avultada pela espontaneidade de Solomon, que não se utiliza dos mecanismos de conversação enviesada do trecho anteriormente citado. Logo que pode, Solomon a criva de perguntas, demonstra genuíno interesse por sua saúde e se oferece para levá-la de carro até à casa da irmã, oferta que é feita depois de ele se referir a uma carta que a irmã escrevera a Dorothy e que esta dissera não haver ainda respondido, na tentativa de cortar o assunto. O leitor já sabe que a irmã está morta e mais adiante saberá que a tal carta se trata de um envelope com coisas escritas por Dorothy a si própria. Aqui também haverá suspensão da ação por um momento: Dorothy oscila entre a compreensão e solidariedade para com a solidão desse homem que pouco conhece e a irritação que sente em relação à sua interferência. Outra vez a personagem se serve de um clichê bastante difundido sobre a atitude respeitosa que se deveria ter para com a comida. É um recurso usado aqui de forma bastante próxima daquela anteriormente utilizada através provérbio sobre a substituição do descanso por uma mudança - "uma mudança equivale a um bom descanso". Na verdade, com o clichê sobre a comida, haverá um efeito irônico mais forte devido ao fato de envolver um outro personagem e uma esfera social mais ampla. Veja-se o texto:

"Esse homem tão estranho. Zelador de Stoneleigh. O faz-tudo do condomínio e a sua moradia que não precisa pagar. Solomon e seu carro de segunda-mão. Sem sequer um cachorro. Apenas ele mesmo, só, escondido atrás das venezianas, à espera de uma calha que precise de conserto ou de uma maçaneta que precise ser trocada. À noite, vejo-o em sua ronda patrulhando o condomínio. A enfermeira irlandesa havia me dito que se eu não quisesse pegar o ônibus da minha cidade para ir ao hospital havia dois motoristas voluntários para esses casos. E depois, um dia à tarde, dentre tantas pessoas, ele me aparece à porta. Um cavaleiro com a armadura reluzente e a carruagem polida. E agora Solomon quer me levar de carro ao litoral para que eu possa passar um tempo com Sheila e a pergunta que me vem à cabeça é por que é que ele não termina o seu kebab de carneiro? No mundo há gente morrendo de fome que faria qualquer 
coisa por um pouco dessa carne." ${ }^{36}(\mathrm{DS}, 19)$

A atitude de Solomon é de autêntico interesse pela recuperação de Dorothy e ela, por sua vez, percebe nele a bondade e a solidão, mas a comunicação de ambos fica truncada porque, embora haja forte intuição mútua sobre o estado em que o outro se encontra, há um grande fosso quanto a dados concretos da experiência de um e de outro. No mínimo, Dorothy desconhece todo o passado desse "homem estranho", de sua vida na África, e Solomon expressa sua crença na família, supõe que Sheila esteja viva e que seja saudável para Dorothy conviver com ela, pois imagina ser "tudo o que lhe restou"(DS,19). A impaciência de Dorothy quanto à espontaneidade e intromissão de Solomon, o fato de se referir mentalmente aos famintos do mundo que dariam tudo para comer um pouco do que estava servido bem à frente, acentua para o leitor a diferença que se coloca entre eles. Supõe-se que Dorothy escolhera o restaurante de comida mediterrânea e somali porque, de partida, pensara agradar o seu convidado, talvez como forma de agradecer pelo serviço de chauffeur voluntário. Não se sabe de que canto da África veio Solomon, mas a comida somali possivelmente seria do seu agrado -- é o que o leitor pode imaginar quanto à motivação da escolha de Dorothy:

“[...]Uma vez escolhi o restaurante de comida mediterrânea e somali e parece que passou a ser o nosso ponto regular, embora eles pudessem manter o lugar um pouco mais limpo. De qualquer forma, parece que ele gosta." ${ }^{37}$ (DS,18)

O quesito da limpeza acentua as diferenças, denota o fato de o lugar não ser bom o suficiente para Dorothy, mas agradável ao africano, na concepção dela. A existência de um restaurante com comida típica da Somália em pleno interior da Inglaterra e a sua disponibilidade entre muitos como objeto de escolha de uma refeição, junto à noção que temos do grau em que grassa a fome por toda a verdadeira Somália ${ }^{38}$ bem como por outros

36 Traduzido acima por mim. No original:"This strange man. The caretaker at Stoneleigh. The estate handyman in his free bungalow. Solomon and his second-hand car. Not even a dog. Just him alone, hiding behind those blinds, waiting for a piece of guttering that needs fixing or a door handle that has to be replaced. At night I see him out on patrol with his torch. The Irish nurse told me that if I didn't want to take the bus into town there were two volunteer drivers. And then, one afternoon, of all people, he came and knocked on my door. My knight in shining armour with his polished chariot. And now Solomon wants to drive me to the coast so that I can spend some time with Sheila, and all I'm thinking is why doesn't he finish his lamb kebab? There's people in the world who are starving to death and who would do anything for a bit of lamb kebab." (DS,19)

37 Traduzido por mim. No original: “ [...] Once upon a time I chose the Somalian and Mediterranean Food Hall and it now seems to have become our regular, although they could keep the place a little cleaner. Still, he seems to like it." (DS,18)

38 Além de ter passado mais de um ano e meio sem chuvas e de se apresentar como um país praticamente sem governo, de população majoritariamente nômade, que subsiste do gado e da criação de manadas de camelos e 
países da região, principalmente as do leste africano, são índices importantes que não devem ser tomados apenas como detalhes periféricos de suporte à ação principal, que, no caso, é a conversa e a relação que se inicia entre Dorothy e Solomon. São índices que irradiam maior carga de sentido quando retomados após a leitura do segundo segmento, focado nos primeiros tempos de Solomon recém-chegado ao território inglês - a comida ruim que lhe é trazida e vem num saco plástico (fish and chips), a comida gordurosa cujo cheiro de fritura saturada o enojara (DS,185) e faz que recuse repeti-la, embora esteja com fome, fome de uma pessoa que sobreviveu a uma viagem clandestina muito difícil.

Sobre a relação que vai se estabelecendo há o impulso de se criar um laço verdadeiro entre os dois protagonistas e dá-se uma aproximação que levará ao fortalecimento dessa vontade vista nas atitudes dos dois que convergem para o mesmo fim, vista na preocupação de um com o bem-estar do outro. O narrador em cada um dos dois primeiros segmentos, seja em primeira pessoa, narrador-personagem, seja o onisciente em terceira pessoa, focado na trajetória de Solomon, se esmera em registrar, de maneira sutil, a curiosidade de um personagem pelo outro, curiosidade que não é um capricho passageiro motivado pelas diferenças étnicas e culturais, mas que é vontade de conhecer o outro, acompanhada de admiração por características que um intui a respeito do outro, de cuidado e também de ligeira desconfiança inicial.

A amizade que se esboça adquire força, ainda mais se posicionada em meio ao mar de contatos superficiais e insatisfatórios descritos ao longo do segmento: tomem-se como exemplo o "sorriso cretino" do médico (DS,17), a intromissão da vizinha que, ao defender a filha preguiçosa, aproveita para dizer a Dorothy que as pessoas fazem comentários a respeito da sua sanidade (DS,23), a curiosidade e interesse sádico da vendedora da revistaria (DS,38), o preconceito velado mas bem transmitido pela enfermeira (DS,299,300), a simpatia ambígua do dono do bar (DS,62).

No entanto, se colocada no plano dos acontecimentos que antecedem a ação no presente, encarada sob o prisma das experiências vividas - de que o leitor só terá noção completa ao final de todos os segmentos --, a relação entre Dorothy e Solomon se esboça de maneira bastante tênue. O registro da amizade compreende um número bem reduzido de encontros: as ocasiões em que Solomon serviu de motorista a Dorothy levando-a ao hospital

burros que mingüam por causa da seca, a Somália e a região conhecida como o "chifre da África" não têm recebido ajuda de alimentos doados pelo World Food Programme, segundo Jeremy Hulme, executivo do SPAMA, conforme divulgado pela BBC em setembro de 2006. 
na cidade próxima, a conversa que travam durante as refeições após a consulta, o dia em que Solomon vem se oferecer como motorista voluntário e duas ocasiões em que um vai à casa do outro para uma breve visita.

Já sob o prisma da experiência psíquica, da vida interior, a amizade entre os dois adquire força propulsora na narrativa, abre a perspectiva de esperança de um contato genuíno e serve para dar concretude à vida de Dorothy no presente e torná-la um pouco menos dominada pela rememoração. Se tomada contra o corpo total do romance, a relação de Dorothy e Solomon acena para uma possibilidade de abertura para o futuro, um momento de simples desapego em relação à vida padronizada, desumanizada e dessacralizada do cotidiano. $^{39}$

A solidão, marca intrínseca e impressa em cada um dos protagonistas, revela-se como “condicionada objetivamente", representa um "destino social específico" como se entenderá ao longo do romance. Essa marca não é resultado de uma "condição humana" universal, não é angst inescapável, mas é fruto do ambiente social específico e da historicidade ${ }^{40}$. Está capturada pela linguagem do romance e enredada na apresentação da fábula, de forma que, quer seja o interior da Inglaterra ou Londres, como emblema dos padrões de desenvolvimento da vida no Ocidente, quer sejam os povoados e cidades da África subsaariana, nenhum lugar serve como "pano de fundo". Capaz de transformação e também de aproveitamento das formas tradicionais, o realismo de Caryl Phillips em A Distant Shore, surpreendentemente com menor recurso à utilização de linguagens criadas ou recriadas, reconhecíveis para marcar a História, como fez em Cambridge, Crossing the River e The Nature of Blood, dá conta nessa sua narrativa mais despojada de 2003, de engendrar uma eficaz embreagem entre o particular e o geral, o psíquico e o social, entre diferentes visões de mundo, entre o passado das personagens e o presente que querem ver modificado. A relação de Solomon e Dorothy e, principalmente, a possibilidade que haveria para o seu crescimento e enraizamento, constitui um horizonte quase utópico, tábua de salvação de cada um:

“[...]Gostaria de ter alguém com quem falar e essa mulher é uma mulher de respeito. É uma mulher para quem poderia contar a minha história. Se não compartilhar a minha história é como se eu só tivesse vivido este último ano de minha vida. Como se fosse um homem de um ano de idade a caminhar com passos pesados. Sou um homem vergado pelo fardo de uma história oculta.[...]. Ela é uma mulher de respeito e talvez a enfermeira esteja errada. Pode bem ser que

39 A propósito do conceito de mediação, F. Jameson usa esses termos em relação à vida cotidiana, Umwelt, em Jameson, Frederic. The Political Unconscious. Ithaca, Nova Yorque: Cornell University Press, 1985, p. 42. 40 Ver a respeito as idéias de Lukács em seu "The Ideology of Form”. In: Eagleton, T. \& Milne, D. (org.). Marxist Literary Theory. Oxford: Blackwell, 1996, pp. 144,145. 
ela não goste do ônibus. Talvez a preferência pelo ônibus seja apenas temporária. Bato-lhe à porta novamente." ${ }^{, 1}$ (DS,300)

O preconceito é a principal causa do isolamento de Solomon e aparece em uma de suas formas comuns, sendo registrado com perfeição através das elipses e dos subentendidos, para ser retomado ainda uma vez e subvertido, sem ser explicitado, quando Solomon se refere à fala da enfermeira. Esta parece ser bastante solícita à primeira vista, mas procura dissuadi-lo de tentar servir como motorista a Dorothy, dizendo que ela provavelmente "gostaria do ônibus"(DS,299) e colabora para que afinal acabe servindo como motorista a um velho racista que se mantém calado e demonstra o rancor pelos gestos durante os percursos até o hospital:

\footnotetext{
“[...]Ontem fui até a enfermeira outra vez para lhe dizer que ninguém havia ligado. Ela pareceu meio constrangida e então me disse que se passasse lá por volta das dez horas, um certo Sr. Simons estaria à minha espera para que eu o levasse ao hospital. Em seguida me contou que o Sr. Simons não tinha telefone, como se isso fosse motivo de vergonha. Fiquei parado um instante, imaginando se havia mais alguma coisa que ela quisesse me falar. Na verdade era eu que tinha algo ainda a dizer.

-Aquela senhora que mora do lado da minha casa. Não sei o nome dela. -- Percebi o olhar intrigado da enfermeira e descrevi minha vizinha. A enfermeira manteve o ar intrigado e então mencionei o endereço.

- Ah, sei quem é. -- E parou um momento.-- Sabe, para dizer a verdade, acho que ela prefere o ônibus." ${ }^{42}$ (DS,298,299)
}

O fato de a enfermeira confidenciar uma informação a Solomon a respeito do Sr. Simons - homem pobre e não-possuidor de telefone --, de dar a entender pelo tom a sua desaprovação disso, acrescido ao fato de hesitar, titubear, não entender logo quem é Dorothy o leitor bem sabe que é professora e tem boa aparência - são indicações da mensagem não expressa: o africano negro que se oferece como motorista voluntário para os pacientes do hospital é bom o suficiente e adequado para um velho pobre, meio sujo e rabujento, mas não para uma mulher branca de classe média.

Essa breve passagem faz lembrar outra mais explícita no romance Crossing the River,

41 Traduzido por mim. No original: “[...]This is a woman to whom I might tell my story. If I do not share my story, then I have only this one year to my life. I am a one-year-old man who walks with heavy steps. I am a man burdened with hidden history.(...) I knock on her door. She is a respectable woman and perhaps the nurse is wrong. Perhaps this woman does not love the bus. Perhaps her love for the bus is merely temporary. I knock again." (DS,300)

42 Acima traduzido por mim. No original: “[...]Yesterday I visited the nurse and informed her that not one person had telephoned me. She appeared somewhat embarrassed, and then she told me that if I came this morning at ten o'clock, then a Mr Simmons would be ready for me to transport him to the hospital. She confided that this man did not possess a telephone, as though this was something that Mr Simmons ought to be ashamed of. I lingered for a moment, for I wondered whether there was something further that she wished to say to me. But the truth was there was something that I wished to say to her." (DS,298,299) 
em que, na época da Segunda Guerra Mundial, uma jovem inglesa e branca, bastante deprimida, ao dar a luz ao filho no hospital, filho gerado por seu romance com um soldado americano negro, ouve da enfermeira: "Ele é da cor do chocolate, não é, meu bem?" (CR,228).

O preconceito exerce uma função poderosa, capaz de se irradiar sob várias formas, de permanecer subjacente e por bastante tempo além dos momentos em que emerge, quer sejam os episódios em que se apresenta meio velado, atrás de meias palavras, de gestos pequenos e de subentendidos, como visto acima, quer sejam os episódios em que é mostrado mais explicitamente, nas cartas abjetas que Solomon recebe, no envelope adulterado contendo pedaços de lâminas cortantes (DS,40), os excrementos de cachorro deixados na sua caixa de correspondência (DS,299), as agressões e ameaças que sofre perto do canal onde passeia por parte de um pequeno bando de jovens racistas vestidos como skin heads (DS,292,294), as pichações carregadas de ódio pintadas na fachada da casa onde se hospedara antes da mudança para o condomínio (DS,287).

Sem dúvida há ainda muitos outros exemplos espalhados pelos vários segmentos que poderiam se agrupar num pequeno inventário das diferentes faces e manifestações do sentimento. Mais importante do que a variedade e quantidade de situações em que se expõe o preconceito é a maneira como se o apresenta, pois causa forte impressão a utilização de uma forma indireta de abordagem, a referência ao ódio racial em pouquíssimas palavras, muitas vezes através dos hiatos presentes, nas palavras não propriamente escritas mas sugeridas nos significados que pairam no ar e que, ao contrário de um resultado eufemístico, produzem um efeito devastador. O impacto que se obtém vem precisamente do fato de não ter sido preciso explicitar, dar detalhes, achar as palavras exatas habitualmente usadas nas agressões racistas. O autor optou por fazer referência aos ataques racistas de forma sugestiva e por descrever sucintamente as reações dos que deles foram alvo por muitas vezes. A forma escolhida para expressar o preconceito é a de ir fundo nele através da menção em poucas palavras, da invocação do problema por meias tintas, de pisar levemente num campo minado em que pode haver explosões a cada passo.

Retome-se a previsão de E. W. Du Bois ${ }^{43}$ de ser o preconceito o principal problema do século XX e lembremo-nos de que a fabricação e a execução do fascismo antes e durante a Segunda Guerra apoiaram-se bastante na manipulação do sentimento racista, sentimento que 
foi adaptado e esteve presente nas diversas campanhas militares nos processos de desumanização do que chamaram de "inimigo", nos genocídios, nas guerras de "limpeza étnica", e que está presente sob outra forma no nosso tempo na indiferença para com as populações abandonadas à própria sorte, para com os contingentes de pessoas desterritorializadas $^{44}$ pela fome, pela perseguição étnica, pela guerra civil e pelas guerras em geral.

Qualquer um de nós que acompanhamos os acontecimentos da História, particularmente os do último século e da primeira década do recém-iniciado terceiro milênio, forçosamente deve ter aprendido a desenvolver mecanismos para anestesiar o efeito de saber das catástrofes que continuam a acontecer e a adquirir novas roupagens. A sintética imagem do Angelus Novus elaborada na tese número nove por Walter Benjamin, aberta à reinterpretação do que seja o progresso, reaviva a nossa percepção da realidade:

"Minhas asas estão prontas para o vôo,

Se pudesse eu retrocederia

Pois eu seria menos feliz

Se permanecesse imerso no tempo vivo."

Gerhard Scholem, Saudação do Anjo

Há um quadro de Klee que se chama Angelus Novus. Representa um anjo que parece querer afastar-se de algo que ele encara fixamente. Seus olhos estão escancarados, sua boca dilatada, suas asas abertas. $\mathrm{O}$ anjo da história deve ter esse aspecto. Seu rosto está dirigido para o passado. Onde nós vemos uma cadeia de acontecimentos, ele vê uma catástrofe única, que acumula incansavelmente ruína sobre ruína e as dispersa a nossos pés. Ele gostaria de deter-se para acordar os mortos e juntar os fragmentos. Mas uma tempestade sopra do paraíso e prende-se em suas asas com tanta força que ele não pode mais fechá-las. Essa tempestade o impele irresistivelmente para o futuro, ao qual ele vira as costas, enquanto o amontoado de ruínas cresce até o céu. Essa tempestade é o que chamamos progresso. ${ }^{45}$

No artigo"Finding Oneself at Home"46, Caryl Phillips afirma ser a diáspora africana, que ele próprio representa, a pedra basilar temática de sua criação literária já há mais de vinte e cinco anos. Com esse romance, de fôlego menor e âmbito mais restrito no tratamento de acontecimentos históricos do que Crossing the River, consegue, ainda assim, atingir com agudeza o problema visto por Du Bois ${ }^{47}$ como o fundamental do século XX.

44 Conforme Eric Hobsbawm . Ver nota n 7. Os acontecimentos desde 1990 só corroboram suas palavras. 45 Benjamin, Walter. "Sobre o conceito da História". Magia e Técnica, Arte e Política. São Paulo: Editora Brasiliense, 1996, $10^{\mathrm{a}}$ reimpressão da edição de 1985, p.226.

46Phillips, Caryl. "Finding Oneself at Home", acessado em 15/02/2006 em www.timesonline.co.uk/article/Sunday

47 Du Bois, W.E.B.[1903].The Souls of Black Folk. London: Dover Publications, 1994. 


\section{LIBERDADE PELO AR}

Como de costume nos romances escritos por Caryl Phillips -- excetuando-se parcialmente os dois primeiros, The Final Passage e A State of Independence, que não seguem tão à risca o arranjo da composição --, terminada a leitura de um primeiro segmento, o leitor se depara, no segundo, com uma narrativa que, à primeira vista e quase até o final se apresentará como uma outra estória, independente da primeira. Em todos esses romances e, particularmente em Crossing the River, Cambridge e The Nature of Blood, os segmentos podem apresentar contextos geográficos de épocas díspares. Em Crossing the River há saltos surpreendentes: a criação artificial da Libéria por iniciativa da American Colonization Society no começo do século XIX, o desbravamento do Oeste nos Estados Unidos já na segunda metade do mesmo século, o tráfico triangular de escravos no século XVIII e o modo de vida no interior da Inglaterra durante e após a Segunda Guerra Mundial. Já em Cambridge não há disparidade temporal, pois as personagens atuam em unidade de tempo ou paralelamente e os caminhos de seres oriundos de formações sociais muito diferentes convergem no espaço problemático de uma plantation no Caribe no século XIX até que tudo se entrelaça através de um assassinato. Em The Nature of Blood há variadas narrativas, com disparidade de tempo e espaço, mas que se apresentam mais entrelaçadas no interior de cada segmento.

$\mathrm{O}$ fato de um segmento seguinte ao de abertura apresentar uma narrativa que se revela surpreendente, quer seja profunda ou aparentemente independente do inicial, opera uma quebra demarcada na expectativa de qualquer leitor. Em A Distant Shore o choque é certeiro: saímos da melancolia e estagnação em uma cidade do interior da Inglaterra para cairmos na opressão de uma prisão em uma cidade bem afastada de Londres. Serão contundentes as descrições de mal-estar físico: sede, fome, dores no corpo, náusea, vômito e sangue, delírio e morte. No segundo segmento os espaços e ambientes pelos quais circula o protagonista são inóspitos e são maioria as situações em que é tratado com desdém ou ignorado. Narram-se um mal-estar quase contínuo, situações de privação e humilhação que se acumulam quase sem trégua.

Aqueles já acostumados com essa técnica do escritor iniciam a leitura antecipando o surgimento de uma ligação mais concreta entre essas partes que formam o romance e sabem que seu papel de leitores é o de ativar as articulações ali delineadas. A meu ver, a 
fragmentariedade em Caryl Phillips parece ter uma motivação específica, diferente do mero modismo entre escritores contemporâneos, que muitas vezes produzem textos espatifados e colocam tudo numa espécie de caldeirão pós-moderno sem causa justificada, a não ser a de atender a certo gosto em voga.

Em Caryl Phillips, as diversas narrativas apresentam-se postas em adjacência ou entremeadas, por estarem, na maioria, ligadas a situações sociais em que há divisões fundamentais entre os seres humanos, cisões que cerceiam a vida social, fenômenos predatórios de forte cunho histórico, que determinam a forma da elaboração da matéria narrada. A temática de seus romances tem evidentes referências históricas: relações interraciais durante ou após a escravidão, durante ou após a independência de uma nação, sob o Conselho de Trento, ou sob o nazismo. Trata-se sempre de ficção a respeito de questões fundamentais para a compreensão das relações interpessoais em contextos históricos opressores, que pesam sobre a liberdade das personagens, e exercem tensões que tolhem a vida cotidiana, e limitam ou impedem a esfera da ação individual. É ficção que exige que se reflita sobre as sociedades humanas em diversos contextos, tais como o tráfico de escravos, as formas de vida nas propriedades do tipo plantation da Jamaica, a vida de escravos durante e após a Emancipação nos Estados Unidos, variadas formas da diáspora africana, migrações por diversas motivações, etc. O sociólogo Paul Gilroy analisou vários aspectos da experiência da escravidão africana e a viu como causa de os negros serem o primeiro povo realmente moderno, "lidando no século XIX com dilemas e dificuldades que apenas se tornariam a substância da vida cotidiana na Europa um século mais tarde" ${ }^{\text {48 }}$. E para explicitar melhor o argumento, citou a escritora Toni Morrison:

“[...] a vida moderna começa com a escravidão... Do ponto de vista das mulheres, em termos de enfrentar os problemas que o mundo enfrenta agora, as mulheres negras tiveram de lidar com problemas pós-modernos no século XIX e antes. Essas coisas tiveram de ser abordadas pelo povo negro muito tempo antes: certos tipos de dissolução, a perda e a necessidade de construir certos tipos de estabilidade. Certos tipos de loucura, enlouquecer deliberadamente, como diz uma das personagens no livro "para não perder a cabeça". Essas estratégias de sobrevivência constituíam a pessoa verdadeiramente moderna. São uma resposta a fenômenos sociais predatórios. Você pode chamar isso de ideologia e de economia, mas trata-se de uma patologia. A escravidão dividiu o mundo ao meio; ela o dividiu em todos os sentidos. Ela dividiu a Europa. Ela fez dos europeus alguma outra coisa: ela fez deles senhores de escravos, ela os enlouqueceu. Não se pode fazer isso durante centenas de anos sem que isso cobre algum tributo. Eles tiveram de desumanizar não só os escravos, mas a si mesmos. Eles tiveram de reconstruir

48 Gilroy, Paul. (1993)“Uma história para não se passar adiante” In: O Atlântico Negro - Modernidade e Dupla Consciência. Trad. Cid K. Moreira. São Paulo: Editora 34, 2001. Gilroy não trata levianamente as atrocidades da história da escravidão africana, mas ressalta a capacidade de os escravos terem desenvolvido formas de sobrevivência e resistência. 
tudo a fim de fazer esse sistema parecer verdadeiro. Isso tornou tudo possível na Segunda Guerra Mundial. Tornou necessária a Primeira Guerra Mundial. Racismo é a palavra que empregamos para abarcar tudo isso."49

O segundo segmento de $A$ Distant Shore não foge à regra de composição de outros romances do autor: constitui uma narrativa de tamanho médio - com pouco menos de 120 páginas - que, ao mesmo tempo em que se sustenta por si, já que poderia ser compreendida sozinha como se fosse uma novela, com seu próprio começo, meio e fim, articula-se pelo desfecho surpreendente, com o primeiro segmento já lido, dando-lhe novas significações e obrigando o leitor a repensá-lo cuidadosamente à luz da revelação inesperada sobre o protagonista, ou seja, a de que Gabriel e Solomon são a mesma pessoa. Na verdade, semelhante efeito se dá com os outros segmentos: conforme os atravessa pela leitura, o leitor os vai recolocando em determinadas posições e refletindo sobre o efeito que se produz, tal como se fossem engrenagens que se fossem acomodando numa formação geométrica, semelhante a um cubo mágico. Esses rearranjos e reflexões que o romance impõe dão-lhe uma vitalidade particular, compatível com a gravidade da matéria narrada e, assim, fazem que escape da configuração das obras realistas mais tradicionais, nas quais poderia haver pouco espaço para que o leitor lidasse com quaisquer ambigüidades ou indeterminações. Em $A$ Distant Shore, a ambigüidade e a indeterminação são marcas encontráveis na relação entre os protagonistas, Dorothy e Solomon, relação esfumaçada - nem amizade profunda, pois que tem curta duração, nem experiência amorosa, apesar de ser depositária da esperança de cada um deles em seus contextos díspares. Ao final do romance, pode ser vista como comunicação truncada: nenhum dos dois protagonistas fica a par da história completa do outro; há apenas um vislumbre, intuição do que o outro é e de sua importância e potencialidade de ação coadjuvante para que se recuperassem mesmo parcialmente das perdas já sofridas.

A interpretação participativa do leitor é que irá abrir um outro espaço, capaz de traçar mais fortemente essas linhas de possibilidades esboçadas entre as personagens e os espaços geopolíticos que representam. A melancolia que permeia os enredos específicos de cada protagonista e o enredo maior que os recobre se justifica porque as vidas destroçadas são protótipos, em escala menor, da real fratura nas sociedades em questão. O leitor vai pensar sobre aspectos do mundo atual que também o desorientam: sobre a falta de interatividade, sobre a segregação entre os espaços desenvolvidos do Ocidente (diversas localidades na Inglaterra) e espaços arcaicos fora do Ocidente desenvolvido (algum lugar na África e muitos 
outros no percurso até à civilização ocidental)..

De maneira geral, toda a narrativa de $A$ Distant Shore é um desmascaramento dos discursos em favor da globalização. Registra-se, já no título, um lugar que se anuncia longínquo e "praia”, ou o plural "praias", que são palavras também tradicionalmente usadas como sinônimo para "localidades" e "países". Mesmo em língua inglesa pode-se usar "other shores" em referência a países estrangeiros, em oposição a "these shores", referentes à GrãBretanha. "Distant" nega a idéia de fácil acesso, tão difundida na chamada "vida globalizada", em que se afirma que as fronteiras e as barreiras podem ser facilmente anuladas por meio da aquisição de simples passagens aéreas ou equivalente a isso, ou pelos recursos da tecnologia eletrônica.

O segundo segmento difere muito do primeiro de vários modos. É uma parte do romance que se desenrola com maior número de núcleos narrativos e peripécias, com elementos mais próximos das características do romance de aventura, de um certo aspecto romanesco mais acentuado aqui e ausente no anterior. Aqui se molda um protagonista que é verdadeiramente guiado pela luta (agon) e nos faz lembrar remotamente, guardadas as devidas diferenças entre o nosso mundo e o dos gregos da antigüidade, de um herói das epopéias: um "ser poderoso, possuidor de coragem e força extraordinárias" provações e se desloca em viagem por um período ritual, espécie de descida aos infernos, antes de voltar a se estabelecer em uma situação mínima de equilíbrio.

O primeiro segmento, regido pela perspectiva de Dorothy, personagem feminina que se aproxima da fase mingüante de sua vida, se desenrolara mais arrastado, em ritmo apropriado à rememoração de experiências sentidas de forma atomizada, na esfera da privacidade, próxima ao que Walter Benjamin denomina Erlebnis ${ }^{51}$. Já este segmento, com narrador que adere à perspectiva de Gabriel, africano que empreende a busca de um rumo para a própria vida, de forjar um destino afastado da matança e da miséria da África, tem uma forma com maior coloração rítmica, com intensidades variadas em sua fabulação, com características dinâmicas que remetem a história da personagem a algo que se assemelha ao conceito de Erfharung ${ }^{52}$,também proposto por W. Benjamin, que diz: "Escrever um romance significa descrever a existência humana, levando o incomensurável ao paroxismo",53. A 50 Aubreton, Robert. "Dados Religiosos: os Heróis”. In: Introdução a Homero. São Paulo: Difusão européia do Livro e Edusp, 1968. p. 145.

51 Benjamin, Walter. Magia e Técnica, Arte e Política. Obras Escolhidas vol. I. (Trad. de Sérgio Paulo Rouanet; prefácio de Jeanne Marie Gagnebin) São Paulo: Editora Brasiliense,1996, p. 15.

52 Idem. Ibidem, p.15.

53 Idem. Ibidem, p. 55. 
riqueza de experiência que vive a personagem Gabriel cria um sentido de expectativa propício para que o leitor pense sobre a natureza de avanços e retrocessos, que se aprofundam e interpenetram na forma do romance, mas que também se encontram na vida social neste início do terceiro milênio, e para os quais nem sempre estamos atentos.

Não parece errado que se encontrem em algumas narrativas de emigração e imigração, principalmente quando se referem aos imigrantes ditos "ilegais", que entram clandestinamente nos países desenvolvidos arriscando a vida, passando por grandes privações e aflições, alguns traços comuns com as façanhas descritas na literatura épica. No segmento em análise, a narrativa da viagem, tema dos mais antigos e disseminados na tradição literária - lembremo-nos da Odisséia, d'Os Lusíadas, Don Quixote de la Mancha, e também d'As Viagens de Gulliver, The Grapes of Wrath e de Vidas Secas, dentre tantas obras a exemplificar --, tem função central e se articula com o processo de formação do caráter do jovem Gabriel, de seu amadurecimento concomitante ao conhecimento de um mundo geográfico que se expande sempre negativamente para si, e da sedimentação de sua identidade.

No segmento, a viagem não é apenas recurso literário para conduzir a fábula; ela de fato apresenta ao leitor uma experiência humana imaginada que, no entanto, não pode ser compreendida em profundidade se não se levarem em conta as notícias e os relatos das difíceis viagens empreendidas por homens e mulheres reais no mundo atual. Quando as personagens têm que decidir se saltam do alto, por uma grande distância, para caírem em cima de um trem em movimento, é bem possível que o leitor se recorde dos milhares de mexicanos que morrem em tentativa semelhante para entrarem nos Estados Unidos. A viagem no romance liga-se à Erfharung, que tem por base verbal "viajar", "atravessar uma região onde há perigos", e um desses perigos, que cabe à literatura examinar, é o da desagregação mental.

A ação é elemento fundamental nesta parte do romance: há um acúmulo de unidades narrativas bem concatenadas para a criação de um efeito de suspense, bem entremeadas, graças às revelações que se apresentam espaçadas e à retenção de dados importantes para que se forme um todo coerente. Sabe-se há muito que a quebra da linearidade exige do leitor uma participação mais ativa na decodificação e interpretação dos romances. Entre nós, os escritores latino-americanos, já nos anos 1970, utilizaram essa técnica com maestria. Porém, particularmente neste segundo segmento do romance, a omissão temporária, a antecipação e o adiamento de certas informações -- como, por exemplo, a natureza da verdadeira acusação que traz o protagonista à prisão na Inglaterra; as circunstâncias de um provável homicídio na 
África --, e o espaçamento entre as unidades em que são abordadas com mais clareza articulam-se em jogo, brincam com pressupostos que o leitor vem a ativar e com preconceitos, bons e maus, que podem aflorar. É brilhante o manuseio desses efeitos operados pela narrativa.

A abertura do segmento faz o leitor confrontar o ambiente de uma cela em uma prisão e já o obriga a participar de forma a pressupor e construir julgamentos a respeito do protagonista. A morte da personagem Felix na África e o abuso sexual de que seria vítima a adolescente Denise são acontecimentos que são postos em dúvida.

O primeiro, o assassinato de Felix, será parcialmente esclarecido e o segundo, o crime contra Denise, será refutado de maneira clara, mas somente quando se chegar próximo do final do segmento. Graças a esse recurso narrativo de postergação, as situações adquirem teor mais grave e o leitor acompanha as incertezas conforme seu modo de ver o mundo. A recorrência dos pesadelos de Gabriel distorcem os fatos ocorridos antes de sua fuga e embaralham, até certo ponto, quem é a vítima e quem, o algoz.

Felix, cuja morte se dá por ter sido golpeado e ferido na cabeça quando Gabriel lhe rouba dinheiro e jóias para poder fugir do país, aparecerá no pesadelo como uma criança que inicialmente, ao persegui-lo, se ri dele com escárnio, e depois o alcança e se mostra consternada, e Gabriel não sabe como reparar o mal que lhe causou. Em seguida, esse menino irá se misturar a pessoas importantes em outros momentos da vida de Gabriel: aparecerá como o filho de Amma, única inspiração de algo positivo nos campos de refugiados. O sentido de ridicularização e escárnio se acentua e se torna mais doloroso, já que afinal vai se ligar ao fato de Gabriel ter sido abandonado por Amma sem qualquer aviso.

No caso referente a Denise, o leitor será atirado para uma posição semelhante à dos advogados Stuart Lewis e Katherine, ou seja, na posição de interlocutores de Gabriel, que dependem de obter maiores informações sobre os acontecimentos que levaram ao processo. No entanto, Gabriel quase não se comunica, o que causa reações diversas nos advogados. Paralelamente, o narrador mantém sua posição em terceira pessoa do singular, quase imperceptível e bastante neutra. Nesse sentido, abre-se uma encruzilhada para as antecipações do leitor: aliar-se a um ou a outro representante da lei. Stuart Lewis mantém-se impassível quase todo o tempo, não expressa qualquer tomada de posição, apenas demonstra impaciência com o africano que não se comunica e se retira logo que lhe é possível. A advogada Katherine parece acreditar na inocência do réu, é capaz de se compadecer dele e de calcular a 
dificuldade abissal de um africano face a uma situação legal numa sociedade complexa que desconhece.

O segundo segmento inicia-se in medias res: Gabriel está preso na Inglaterra sem saber exatamente por quê. Aguarda os trâmites legais e depende da chegada de advogados que o representem num processo no qual é réu. Enquanto espera, na cela dividida com um prisioneiro árabe gravemente doente, relembra diversos estágios de sua vida. Primeiramente, relembra o trauma de, escondido, ver a família assassinada e depois, o impasse que enfrenta ao se ver obrigado a conseguir dinheiro para se juntar a outros emigrantes que querem se livrar do horror na África e partir para a Europa. A realização da longa viagem até as praias inglesas, que compreende uma terça parte da narrativa, situa-se bem no centro do segmento e subdivide-se em várias subpartes referentes às etapas do deslocamento e às transferências feitas em quase todos os meios de transportes conhecidos, por terra, ar e mar, em condições precárias. A certa altura, por um curto intervalo de tempo, fica num acampamento lotado de imigrantes de várias nacionalidades, onde conhece Amma, uma mulher muçulmana, e seu bebê. A última etapa da viagem é uma prova que quase o leva à morte: Gabriel, o jovem africano Bright e um chinês mais velho atravessam o Canal da Mancha apoiados num degrau existente nas paredes externas de um navio, agarrados às correntes de ferro pendentes da embarcação e, quando se aproximam da costa inglesa, atiram-se ao mar e nadam até à praia. $\mathrm{O}$ chinês morre durante a travessia, Gabriel se acidenta ao pular do navio e quase perde a vida já em terra firme, mas é ressuscitado por Bright. Inconsciente, entre a vida e a morte, Gabriel percorre mentalmente o passado vivido na África. Revê a juventude de rapaz pobre pertencente à tribo menor do país que havia pouco se tornara independente, a indiferença sentida na época em que trabalhara como office boy em um departamento do governo na capital. Revê também a entrada na maturidade, a experiência como soldado e como líder de um grupo pertencente ao exército de libertação, em guerra contra as forças do governo, constituídas por homens da tribo maior, bem como a experiência de combates através do país, as reações às drogas e as diversas atuações de seus homens em delírio, e a insubordinação de todos que, contra as suas ordens, decidem arrasar os vilarejos do caminho, independentemente de serem hostis ou favoráveis à causa da libertação. Por fim, revê a própria dissidência e fuga rumo à casa da família para preveni-los da vingança de que seriam vítimas por parte das tropas do governo, assim que essas soubessem da destruição do vilarejo pelo bando que acreditavam estaria agindo sob o seu comando. 
Em território inglês, já reavivado, os dois sobreviventes da travessia, Gabriel e Bright, se abrigam em uma casa abandonada e logo visitada por Denise, uma adolescente inglesa que lhes traz água e comida. Com dificuldade, Gabriel se recupera do ferimento na perna, mas se deprime por ser abandonado inesperadamente pelo amigo africano, Bright, que rumou para a capital e se desvencilhou do fardo de um acompanhante convalescente.

De volta ao fio condutor inicial, vemos Gabriel no espaço da prisão, onde tem algumas entrevistas com os advogados que, repentinamente, comunicam-lhe a novidade: pode deixar a prisão, já que a adolescente Denise se recusara a depor no processo de suposto abuso sexual. Denise agira inicialmente por ordem do pai alcoólatra que, na tentativa de conseguir indenização, caluniara o estrangeiro. A advogada Katherine, sensível à situação de Gabriel, lhe empresta algum dinheiro, lhe dá seu endereço de casa para o caso de alguma emergência e organiza sua saída da prisão em segurança, de forma a evitar o assédio da imprensa, e aconselha-o a mudar de nome, devido à notoriedade do caso e à perseguição de que, de outro modo, seria alvo para o resto da vida ${ }^{54}$.

Gabriel é deixado nas ruas de Londres por policiais racistas que o levam ali de carona, e, na capital, será vítima de golpes aplicados por várias pessoas, inclusive por um africano que se diz seu conterrâneo, que lhe tiram o pouco dinheiro que tem. Depois de muito andarilhar, vai até à casa de Katherine, que o leva de carro até à saída rodoviária da cidade. Katherine novamente lhe dá algum dinheiro e se despede dele no ponto em que Gabriel conseguirá carona para alguma cidade do interior no norte do país. Passado algum tempo, um caminhoneiro irlandês decide levá-lo ao norte. Em resposta às perguntas do motorista conversador, Gabriel confirma ser africano e diz chamar-se Solomon. O motorista comenta que o nome é como o de Salomão na Bíblia, Gabriel concorda e assim se fecha o segmento.

A narrativa desse segundo segmento desenha o arco percorrido pelo africano Gabriel até se tornar o imigrante Solomon. Muito se poderia dizer a respeito das transformações por que passa e como se consegue equilibrar entre os dois pólos ou por meio de uma mistura de ambos. Poder-se-ia também ver a personagem como extremamente propícia a funcionar como modelo típico do conceito de sujeito descentrado, sem identidade fixa ou estável, portador de posições de sujeito deslocáveis em várias direções conforme exigisse o contexto, dando prevalência ora para os interesses da nacionalidade, ora de gênero, de raça, classe social,

54 A mudança de nome para um africano recentemente imigrado pode trazer à memória do leitor as inúmeras situações em que africanos escravizados foram forçados a perder os verdadeiros nomes e batizados conforme a vontade dos senhores. Semelhante episódio encontra-se em "The Pagan Coat", na abertura do romance Crossing the River, de Caryl Phillips. 
geração, etc., não tendo a classe social como identidade mestra, única e abrangente. No capítulo "A identidade cultural na pós-modernidade", o sociólogo Stuart Hall discute conceitos de identidade e de alteridade, a convivência dos enclaves étnicos no interior dos países desenvolvidos do Ocidente, a homogeneização de estilos de vida, concomitante ao movimento contrário de apego às culturas de origem, sendo este passível de resultar em forte nacionalismo ou em crescente fundamentalismo, e, também as possibilidades de reidentificações e de pertencimentos a culturas ditas híbridas. Vejamos:

\begin{abstract}
"Num mundo de fronteiras dissolvidas e de continuidades rompidas, as velhas certezas e hierarquias da identidade britânica têm sido postas em questão. Num país que é agora um repositório de culturas africanas e asiáticas, o sentimento do que significa ser britânico nunca mais pode ter a mesma velha confiança e certeza. O que significa ser europeu, num continente colorido não apenas pelas culturas de suas antigas colônias, mas também pelas culturas americanas e agora pelas japonesas? A categoria da identidade não é, ela própria, problemática? É possível de algum modo, em tempos globais, ter-se um sentimento de identidade coerente e integral? A continuidade e a historicidade da identidade são questionadas pela imediatez e pela intensidade das confrontações culturais globais. Os confortos da Tradição são fundamentalmente desafiados pelo imperativo de se forjar uma nova auto-interpretação, baseada nas responsabilidades da Tradução cultural."${ }^{155}$
\end{abstract}

Com esperança otimista, Hall, ao menos na época (1992), reconhecia a globalização como força impulsionada pelo Ocidente, mas descentradora do mesmo num processo lento e continuado, já que as "metanarrativas" da modernidade, quer fosse o marxismo ou o liberalismo, se verificariam superadas por essa outra dinâmica, segundo a qual não haveria nem triunfo do local (particularismos tais como o nacionalismo e o fundamentalismo) nem do global. Porém, hoje em dia, próximos do ano 2010, não vemos justificativa para a celebração dos desdobramentos da globalização. O romance trata da questão da identidade e mostra a luta do protagonista em manter tanto a vida quanto a sanidade mental na unidade de um eu que teve recursos para passar por épocas em que atendeu por diferentes nomes - Hawk, Gabriel, Solomon. A personagem apresenta uma base de personalidade inquebrável: é protagonista no sentido de ser um lutador, não sucumbe psicologicamente às provas a que é submetido. No entanto, o que se narra é uma sucessão de dificuldades quase intransponíveis, várias situaçõeslimite e humilhações. Na forma do segmento, há também uma força sólida e perceptível na maneira como o narrador adere ao personagem, sendo deste o ponto de vista dominante, apesar da narração em terceira pessoa do singular.

Não há dúvida de que a Grã-Bretanha, mesmo em outros séculos, mas especialmente

55 Hall,Stuart. “O global, o local e o retorno da etnia”. In: A Identidade Cultural na Pós-modernidade (trad. de Tomaz Tadeu da Silva e de Guacira Lopes Louro) . Rio de Janeiro: DP\&A editora, 1999. p.84. 
no período do pós-guerra até hoje, cresceu em muitos aspectos com a força revigorante trazida pelos imigrantes indianos, paquistaneses, caribenhos, africanos, poloneses, ucranianos, etc.. Em 2007 divulgaram-se dados econômicos que apontavam claramente para a contribuição significativa prestada pelo trabalho dessas pessoas, contrariamente à suposição de muitos de que elas apenas vinham se aproveitar dos benefícios do Estado de Bem-estar Social inglês, tradicionalmente tido como exemplar no mundo até meados do período do governo Thatcher. Em outro segmento do romance há um diálogo no qual Mr Anderson, um britânico mais velho, que ajuda Solomon com acomodação e trabalho, trata do assunto e diz que "o sistema está vergando quase a um ponto crítico" (DS,289).

O romance conta uma estória oposta às promessas do mundo globalizado. Vale a pena ressaltar o modo conflitante entre o que de fato ocorre com as personagens que emigram de seus países, as experiências pelas quais passam e o que imaginavam encontrar.

“A Inglaterra mudou”, frase repetida no pensamento da inglesa Dorothy no primeiro segmento, carregará ecos para este segundo segmento, portador de várias personagens sedentas por uma oportunidade de viver em liberdade, com trabalho e justiça. Além da angústia e do risco de vida para saírem do próprio país, há um custo concreto para os emigrantes: o iraquiano Said deixou mulher e filho, vendeu terras e gado para obter três mil dólares em troca da viagem; para se juntar ao grupo de homens reunidos na casa do tio Joshua a fim de emigrar com eles, Gabriel rouba o ex-patrão e o mata para obter os dois mil dólares necessários; mesmo já no continente europeu, a muçulmana Amma perde preciosos quatrocentos dólares, preço cobrado por intermediários inescrupulosos que, sem lhe dar explicações, lhe vendem a possibilidade de se atirar com o bebê do alto de uma ponte para cair sobre o teto de um trem em velocidade e, assim, atravessar o túnel da França para a Inglaterra. São várias as passagens em que, muito rapidamente, se fazem negociações de trechos de viagem e em que as personagens ignoram o que as espera. Ao longo da trajetória acentua-se a quantidade sempre crescente de viajantes clandestinos. A cada trecho, a cada novo meio de transporte, e, em vários momentos referentes a breves descrições dos acampamentos de desterritorializados, enfatiza-se a quantidade sempre maior de pessoas de diversas nacionalidades e etnias que surgem. Além dos agenciadores inescrupulosos, há referência a diversos outros profissionais como motoristas, guardas, etc., que é preciso contatar: são personagens descritas por breves pinceladas, com sotaques diferentes e variados níveis de flexibilidade para lidar com os recém-chegados. Seguem-se três exemplos. 
Depois de saírem do avião de carga, ao chegarem em um terminal do aeroporto "os novos imigrantes são levados a atravessar uma porta estreita do outro lado da qual estão posicionados homens com armas que olham para eles sem respeito" (DS,100).

Após a difícil travessia por barco durante uma noite, os imigrantes passam logo para o compartimento apinhado de um trem com destino à França, cujas janelas têm de ser mantidas cerradas. O tio Joshua, ainda liderando o grupo, explica que não podem de maneira alguma abrir as venezianas plásticas que cobrem as janelas e recomenda: "Ninguém pode entrar ou sair, a menos que seja para usar o banheiro. E mesmo assim, só com permissão. Os policiais da alfândega foram pagos mas não nos querem ver" (DS,103).

Antes de poderem entrar em uma das grandes barracas que formam o acampamento dos refugiados no interior da França, os imigrantes são abordados por um oficial que não se mostra contrariado ou hostil, mas revela preocupação com o número de pessoas recémchegadas. O diálogo é breve, posto numa narrativa de tipo "cena", colada ao protagonista de forma a tornar claro para o leitor como Gabriel está despreparado e como não imagina "a cena de miséria letárgica" que verá na barraca, da qual brevemente fará parte:

“-- Vocês são quantos?

Gabriel olha para trás. - Não sei dizer ao certo.

-- Com certeza os homens que largaram vocês na estrada sumiram, não é?

Gabriel concorda.

--Há mais de vocês?

Gabriel não compreende bem o que ele quer dizer com a pergunta e hesita.

-- Há outros de vocês na França?

-- Há. Em Paris.

-- Muitos? Cem? Duzentos?

--Não. Não. -- Gabriel responde com firmeza. --Talvez cem, mas eles não vêm para cá.

O homem suspira alto.

--Bom, fico feliz com isso. A verdade é que nós não podemos receber mais gente. Vai ser difícil com o tanto que vocês são. ${ }^{56}(\mathrm{DS}, 122)$

56 No original: "How many are you?

Gabriel looks behind him. "I am not sure."

"And of course the men who dropped you on the road , they are gone, yes?"

Gabriel nods.

"Are there more of you?"

Gabriel is not sure what the man means, and so he hesitates.

"Are there more of you in France?"

"Yes, in Paris."

"Many? One hundred? Two hundred?" 
Conforme a narrativa da viagem se desenvolve, o grupo de imigrantes aumenta e recebe novos membros, a quem o narrador se refere como "novos imigrantes"(DS,100), “imigrantes exaustos" (DS,103) e "bando de peregrinos"(DS,122). De forma sutil, aos poucos, vai-se caracterizando com mais nitidez a situação de deslocamento forçado, de precariedade e do contingente de pessoas cada vez mais numeroso. O desenrolar da trama assinala o fato de que a experiência atinge muitos outros, originários de outras partes do hemisfério sul.

Nos vários trechos da viagem acumulam-se provações, enunciadas por meio de uma prosa centrada nas ações, com pouco ou nenhum comentário ou juízo de valor por parte do protagonista, de outras personagens ou do narrador onisciente. Porém, o uso concomitante de sintaxe simples, por orações independentes ao invés de subordinadas, a ausência de adjetivos qualificativos, a brevidade e a raridade de diálogos, criam uma narrativa contundente, na qual frases que normalmente passariam sem causar grande efeito recebem uma carga forte. Depois de tudo o que passaram, os imigrantes são olhados sem respeito, devem-se tornar quase invisíveis, pois a polícia alfandegária não os quer ver.

Que a polícia e muitos outros não os queiram ver parece, no mundo em que vivemos, uma verdade trivial. Verdades triviais são tão evidentes que se tornaria desnecessário enunciálas, mas na literatura de Caryl Phillips recebem redobrada força. Qualquer leitor bem sabe que imigrantes indesejáveis não são tratados com civilidade ao entrarem no Ocidente, mas, no contexto criado, a falta de respeito por esses seres humanos se avoluma e o leitor reflete sobre isso. É uma conquista do estilo de Caryl Phillips, o de ser capaz de reavivar o sentido de frases e palavras que parecem ter perdido bastante do seu significado pelo processo de banalização que sofrem em nossos dias.

Lembre-se de que, desde o primeiro segmento, sabe-se que essa situação ou uma situação semelhante perdurará com nova roupagem: os vizinhos não querem ver Solomon, nem mesmo querem utilizar seu trabalho voluntário no hospital. Não querem estar com ele. Solomon espia através da persiana e não há abertura para se relacionar com os moradores. Sente-se despersonalizado, como uma criança de tenra idade que não tivesse vivido: "Se eu não compartilhar a minha história, é como se tivesse então apenas esse ano de vida. Sou um

\footnotetext{
"No, no." Gabriel is adamant. "Perhaps one hundred, but they are not coming here."

The man sighs loudly. "Well, I am happy. The truth is we can take no more. It will be difficult with this many of you." (DS, 122)
} 
homem com um ano de idade que caminha com passos pesados. Um homem vergado por uma história oculta" ${ }^{, 57}$ (DS,300).

Acresce a isso o fato de nunca haver brecha alguma para que o protagonista pudesse ter um mínimo de alívio, contando a alguém a sua história traumática. Na primeira manhã em que Gabriel/Solomon está já no norte, depois da primeira noite em que dorme em uma cama normal, diferente das noites passadas na prisão ou a trancos e barrancos em qualquer dos meios de transportes utilizados na viagem, ele tem vontade de repartir o sofrimento que carrega com a dona da pensão, uma velha senhora escocesa, mas não o faz, nem ela lhe pergunta sobre isso. Esta é outra passagem que retrata bem como o não-dito existe e se faz sentir como realidade pesada; se faz presente ou toma corpo deslocando-se da matéria narrada (o relacionamento das personagens) sem que seja verbalizado no diálogo, mas verbalizado para o leitor. Refiro-me ao que precede as reiteradas negações de Gabriel. Através das repetições de "Eu não disse a ela...", em monólogo interior, afirmam-se, na enunciação do segmento, esses conteúdos reprimidos no diálogo.

A sra. Anderson não ouve de Gabriel/Solomon o relato da sua desgraça e seus variados desdobramentos, mas o narrador implícito criou uma cena carregada de dramaticidade: Gabriel/Solomon capta a receptividade da mulher idosa e ela, por sua vez, capta, até certo ponto, o sofrimento que ele carrega consigo. Não ocorre um diálogo revelador das experiências de Gabriel pois elas não vêm à tona na conversa que travam, mas são registradas, com novo peso, para o leitor, que já as conhece, pois que atravessou os vários estágios precedentes da narrativa . Não se sabe o quanto a sra. Anderson é capaz de empatia, mas o leitor deverá exercer essa função. O romance exige isso. Trata-se de uma passagem que é a culminação de muitas outras relativas à esfera de expressividade do protagonista: sua expressividade não se materializa no exterior, para o interlocutor presente na trama, mas é registrada (no caso é o que ocorre pelas negações) ou é objeto de alusão, com sutileza ou para outro efeito, através de elipses bem posicionadas. Vejamos:

\footnotetext{
"Enquanto continuava a lavar a louça, fazia perguntas sobre mim, de onde eu era, o que esperava fazer de mim, agora que estava na Inglaterra. Embora meu instinto natural fosse não confiar em ninguém, havia algo nessa pequena mulher idosa que fazia com que eu me sentisse em segurança. E então eu contei a ela sobre a dor de partir do meu país, sobre a viagem sem conforto até a Inglaterra e as dificuldades da travessia no barco. Disse a ela que o meu problema maior com a Inglaterra era que às vezes fazia muito frio e que agora que eu
}

57 Acima grifado e traduzido por mim. No original: "If I do not share my story, then I have only this one year to my life. I am a one-year-old man who walks with heavy steps. I am a man burdened with hidden history. (DS,300) 
estava na Inglaterra tinha muita vontade de aprender. Por educação, disse a ela que em minha terra natal as coisas iam muito, muito mal. Que a guerra tinha tornado as pessoas medrosas e que elas não têm nada, e que ninguém quer ficar lá, mas na Inglaterra há paz. No meu país não há paz e os grandes pesares das pessoas não parecem evanescer. Não lhe contei nada sobre Felix, ou Amma, ou meu tio Joshua, ou Bright. Nada lhe contei sobre a forma como sangrara por dentro por ocasião dessas separações; não lhe contei sobre a tentação daquela pobre menina, que era uma das mais abandonadas da sua espécie e que me apresentou a oportunidade de me rebaixar e apenas atender a uma paixão da carne. Não lhe contei sobre Said ou sobre a prisão, onde nunca me condenaram a pagar pena, pois eu era inocente de qualquer crime. Não lhe contei nada sobre Katherine, que tinha me ajudado a superar um pouco o temor oriundo da minha ignorância dos costumes do povo inglês. Nada lhe contei sobre Hawk; nada lhe contei sobre Gabriel. Disse-lhe que meu nome era Solomon e que eu precisava conseguir os papéis para poder trabalhar e ficar na Inglaterra. Disse a ela que não tinha outro país. A mulher secou as mãos num pano de prato e preparou chá. Sentou-se a meu lado e por alguns momentos parecia longe, perdida em contemplação e em pensamentos. Quando voltou à minha companhia, serviu o chá em duas xícaras. ${ }^{58}$ (SD,277,278)

A questão da desterritorialização forçada de africanos e de como se referir a ela de forma expressiva é crucial no segmento e na totalidade do romance. A infelicidade de viver num ponto da África assolado pela guerra e outros problemas como a deterioração das terras pela seca, a perda das formas de subsistência, tais como as perdas das tribos nômades de seus animais por falta de água, a fome como realidade ou ameaça, os poucos ou inexistentes recursos sanitários e hospitalares, a corrupção quase endêmica em muitos países da região, os conflitos étnicos, as atrocidades cometidas são uma realidade freqüentemente apresentada nos meios de comunicação impressos e eletrônicos e por vezes, na literatura-testemunho, semibiográfica, como no caso de Ismael Beah com seu A Long Way Gone: Memoirs of a Child Soldier. ${ }^{59}$ Nos países que sofreram a colonização e fizeram parte do império colonial da Inglaterra ou da França, há bastante divulgação das situações sub-humanas existentes,

58 No original: "As the woman continued to wash dishes, she posed many questions about me, and where I was from, and what I desired to do with myself now that I was in England. Although my natural instinct was to trust nobody, there was something about this small elderly woman that made me feel safe. And so I told her about the pain about leaving my country and the uncomfortable journey to England, and the difficulties of travelling on the boat. I told her that my greatest problem with England was that sometimes the weather was very cool, but now that I was in England I possessed a great desire to learn. To be educated. I told her that at home things are very, very bad. That the war has left people afraid, and they have nothing, and nobody wishes to remain there, but in England there is peace. In my country there is no peace, and the many griefs of the people do not appear to be wearing away. I told her nothing of Felix, or Amma, or my uncle Joshua or Bright; I told her nothing of how my heart bled at these partings; I told her nothing of the temptation of the poor girl, who was one of the most abandoned of her species, and who presented the opportunity to debase myself and simply gratify a passion of nature; I told her nothing of Said, or prison, where I was never condemned to pay recompense, for I was innocent of any crime; I told her nothing of Katherine, who had helped me to overcome some of the fear that arose from my ignorance of the ways of English people. I told her nothing of Hawk. I told her nothing of Gabriel. I told her my name was Solomon and that I needed to acquire papers so that I could work and remain in England. I told her that I had no other country. The woman wiped her hands on a towel, and then she prepared a pot of tea. She sat down next to me, and for some moments she lost herself in contemplation. When she returned to my company she poured two cups of tea. (DS,278)

59 Beah, Ismael. A Long Way Gone: Memoirs of a Boy Soldier. New York: S. Crichton Book/Farrar, Straus \& Giroux, 2007. 
especialmente no continente africano, e muitos são os políticos e os altos funcionários desses territórios que são chamados a vir a público falar a esse respeito. A BBC e os jornais ingleses como The Guardian e The Independent com freqüência trazem reportagens e matérias sobre as dificuldades enfrentadas pelo continente africano. Muitas das novas nações, após a retirada dos colonizadores e da estrutura de administração colonial, ficaram à deriva. A conhecida scramble for Africa - luta de competição para a divisão do continente entre as potências coloniais - deixou marcas que perduraram:

\footnotetext{
“[...]os países colonizadores europeus, segundo suas conveniências, traçaram artificialmente os limites territoriais, dividindo povos e etnias. Especialmente a partir de fins do século XIX, de um momento para outro, parte de um povo africano passou a viver em território pertencente a um país europeu e parte em território de outro país colonizador. O ajuste dessas fronteiras artificiais custou a morte de milhões de pessoas ao longo do século XX como ocorreu em Uganda, na Etiópia, etc., e está longe de ser encerrado." ${ }^{\prime 60}$
}

Uma breve vista d'olhos em jornais e noticiários do momento sobre a África fornece um vocabulário que se repete em relação a diversos países e regiões, como por exemplo "eleições fraudulentas", "instabilidade", "atolados na pobreza", "negligência", "abandono", "falta", "corrupção que grassa", e, principalmente, "estados fracassados" (“failed states"). Este último dá o que pensar: na época em que se preconiza a superação de fronteiras e de amarras e regulamentos impostos pelos estados-nação, há esse continente africano, em cujo território muitas nações não conseguiram se formar convenientemente, e, algumas delas, se já não o fizeram, estão prestes a se submeter à exploração dos novos "global players", tais como a China, interessada em petróleo e outros minerais. Às vezes dá-se um salto fenomenal: de uma organização tribal, de subsistência de forma arcaica, pula-se para o terreno de exploração da China capitalista.

A teoria crítica pós-colonial nos últimos trinta anos do século $\mathrm{XX}$ se deteve bastante na análise das relações entre ocidente e não-ocidente. Um dos pontos analisados por essa teoria foi o uso de uma retórica demonizadora, depreciativa e negadora em relação aos territórios colonizados, quer na África ou no Oriente. Já em Hegel ${ }^{61}$, o continente africano era apresentado como espaço destituído de História, como se sabe. O texto "Negation", de autoria de David Spurr ${ }^{62}$, levanta aspectos que são de interesse mencionar. Caracterizada como figura

60 Ribeiro, Wagner Costa. Relações Internacionais. Cenários para o Século XXI. São Paulo: Editora Scipione, 2004, p. 90.

61 Hegel, G. W. F.. Lectures on the Philosophy of History (1830-1831). Tradução de J. Sibree. New York: Dover, 1956.

62 Spurr, David (1993). "Negation”. In: The Rhetoric of Empire : Colonial Discourse in Journalism, Travel 
da obscuridade e do nada, metaforizada como um vácuo no espaço, a África foi interpretada como lugar sem história, espaço aberto, dependente dos colonizadores para com eles obter uma história significativa. Não só os colonizadores da época vitoriana, mas muitos outros, inclusive autores famosos, em épocas posteriores, vêem a paisagem africana como um abismo devorador, como se fosse desprovida de centro, sem limite ou medida possíveis, devido à vastidão impressionante. ${ }^{63}$

Ainda a respeito da "petrificação do conceito de colônia" e do eterno descompasso sentido em relação a um outro lugar (a metrópole), que parece ter plena conquista de um desenvolvimento que jamais logramos alcançar, Alfredo Bosi cita as palavras de Sérgio Solmi no prefácio da edição italiana de Minima Moralia, referentes à Itália, cuja industrialização se deu tardiamente, em comparação à França ou à Inglaterra, mas que nos podem também representar e trazer luz sobre outros lugares da África e do chamado "terceiro mundo":

"O mundo que Adorno descreve é a moderna sociedade americana; e o termo de comparação de que dispõe é a Alemanha nazista ou pré-nazista. O ambiente em que vive, quando redige Mínima Moralia, é o da imigração alemã nos Estados Unidos. É preciso ter presentes essas circunstâncias para uma avaliação integral do seu livro. O nosso país apresenta, em mais de um aspecto, um panorama muito diferente do que está sob os olhos de Adorno quando escreve estas páginas. Por outro lado, seria errôneo subestimar tudo o que há de comum entre uma sociedade monopolista avançada como a dos EUA e uma sociedade burguesa sui generis como a nossa. Apesar de todas as diferenças de nível estrutural, existe alguma coisa como um espírito do tempo. E isso é ainda mais verdadeiro hoje, quando o aparato técnico e os instrumentos da difusão da cultura de massa determinam uma koiné cultural que muitas vezes se antecipa ao desenvolvimento da economia. A exportação do way of life americano encontra um terreno particularmente favorável justamente onde não existem e talvez não existam nunca - as condições econômicas onde se desenvolveu. O destino dos povos atrasados não é nada alvissareiro. Eles correm o risco de se acharem assimilados sem ter avançado um só passo, e de sofrerem todas as desvantagens do presente somadas às do passado. Não obstante as aparências, o mundo descrito nestas páginas é também o nosso. Valha como advertência aos críticos apressados: de re vestra agitur. ${ }^{64}$

Em relação à África, é chocante ver como se repete a expressão "failed state" em muitas entrevistas com políticos ou representantes africanos, em discussões sobre os obstáculos que muitos países enfrentam, usada com certa arrogância por repórteres e entrevistadores, como se o "fracasso" em se erguerem como nações fosse uma característica generalizada, determinada pela geografia, pelo clima, pela origem do continente, ignorando-se o período de mais de um século de desastrosas políticas de exploração colonial, anterior à

Writing and Imperial Administration. Duke University Press: Durham \& London, 1994.

63 No Brasil, guardadas as diferenças, temos a experiência desses saltos, das incongruências fundamentais que convivem na nossa sociedade, das "idéias fora de lugar", dos contrastes sociais, da desigualdade.

64 Sergio Solmi, prefácio a Minima Moralia. Turim: Einaudi, 1954, pp XVI-XVII. Apud Bosi, Alfredo (1992). Dialética da colonização. São Paulo: Companhia das Letras, 1996. p. 362. 
independência. Há, de fato, muitos fracassos que precisariam ser compreendidos mais a fundo, com maior consideração e senso histórico das diversas situações dos países africanos e dos fatores que os trouxeram a esse estado.

$\mathrm{Na}$ ficção que o segundo segmento de A Distant Shore nos apresenta, está presente uma visão da pátria na África não idealizada, sem afeição ou preocupação, diversa da de Gabriel, e se refere à do companheiro de travessia por mar à Inglaterra. O jovem negro Bright, a tal ponto está decidido a cortar laços com as lembranças de tortura e doenças durante o período em que esteve preso no país de origem que proclama adesão à idéia da GrãBretanha como mother-country, noção essa amplamente difundida pelos administradores do Império Britânico no passado. No momento em que Gabriel desconfia da grande dificuldade que será atravessar o mar, Bright afirma ser essa a única opção para os que não têm dinheiro, além de ser conveniente por se tratar de um meio não tão fiscalizado como os trens:

“[...] É desse jeito, ou então Paris. Mas eu sou inglês. Só os brancos nos respeitam, pois nós não nos respeitamos. Se abrirem o meu peito vão ver o coração marcado com a palavra 'Inglaterra'. Eu falo a língua e portanto vou à Inglaterra pleitear moradia e remuneração.-- Quieto por um momento, logo retoma a fala.-- Meu camarada, é difícil falar disso, mas vou dizer uma vez e depois esquecemos. No nosso país me puseram na prisão e fizeram coisas terríveis para me forçar a falar. Se não fosse por um primo meu que me trouxe dinheiro para eu pagar os guardas e comer, eu não estaria aqui. Tive disenteria por causa do único penico que cinqüenta homens tinham que compartilhar. Peguei piolhos do colchão úmido no chão. $\mathrm{O}$ arroz mal cozido em óleo de palmito aliviava a dor, mas me deixou muito doente. Sei que nós todos sofremos muito, mas eu, este homem que vos fala, não posso nunca voltar. Detesto aquilo tudo. Quero esquecer a África e aquela gente. Agora sou inglês. Sou inglês e ninguém vai me impedir de ir para a mãe-pátria. Nem vocês, nem essas pessoas, ninguém." ${ }^{65}$ (DS, 134)

Por ter sofrido na carne a tortura e o desrespeito aos direitos humanos, prática bastante comum em países do mundo subdesenvolvido, mas não exclusivo deles, e também por sua extroversão, sua força, sua iniciativa e sua falta de sensibilidade, Bright tem um objetivo determinado e acredita na Inglaterra como a solução mágica de todos os seus problemas. Embora secundário e de breve atuação na narrativa, Bright é uma personagem de contraponto

65 No original: “[...]It is either this or Paris. But I am an Englishman. Only the white man respects us, for we do not respect ourselves. If you cut my heart open, you will find it stamped with the word 'England'. I speak the language, therefore I am going to England to claim my house and my stipend." For a moment Bright falls silent, and then again he begins to speak. "My brother, this is difficult to talk about, so I will just say it once and then we can forget it. In our country they put me in prison and did terrible things to me to try to make me talk. If it was not for a cousin who brought me money so I could pay the guards and eat, I would not be here. I got dysentery from the one chamber pot that fifty of us were forced to share, I got lice from the damp mattress on the floor. The half-cooked rice in palm oil soothed my pain, but it made me very sick. I know we have all been afflicted, but I, this man, cannot go back ever. I hate it. I want to forget Africa and those people. I am an Englishman now. I am English and nobody will stop me from going home. Not you, not these people, nobody." 
a Gabriel: caracteriza-se pela tenacidade em sobreviver e por ser imediatista. É o único que sai ileso da terrível travessia do Canal da Mancha. Também age prontamente, socorrendo Gabriel logo que chegam à praia, mas com igual prontidão o abandona sem qualquer aviso quando percebe que o amigo pode ser um fardo e retardar o seu progresso.

A obstinação em sair da África não é só matéria criada no romance, pois no mundo real, há muito tempo, e com maior intensidade nas últimas décadas, há muitos registros das proezas e dos infortúnios por que passam imigrantes ilegais pobres, em busca de sobrevivência e de uma outra vida nos países mais desenvolvidos da Europa ou da América do Norte. Apenas para citar como exemplo recente, em 2007 registrou-se em um documentário apresentado pela BBC uma entrevista com um motorista de ônibus das Ilhas Canárias, cuja rotina, antes de partir para a Espanha, incluía cuidadosa vistoria dos espaços vazios existentes sob a carroceria, especialmente uma parte côncava perto das rodas traseiras, onde era freqüente encontrar meninos e jovens adolescentes encolhidos e escondidos, na tentativa de efetuarem a viagem clandestinamente.

O conceito de hibridismo contém aspectos positivos que não devem ser descartados sem exame, mas só se pode falar nele como uma idéia sempre posterior às reais dificuldades vividas pelos migrantes de uma possível primeira geração que sobreviva no novo país. Nos anos noventa, quando Salman Rushdie trata do assunto no prefácio, também em relação à polêmica causada sobre o seu romance Versos Satânicos, é tomado por um entusiasmo que o faz saltar muito rapidamente sobre as experiências atrozes que os emigrantes enfrentam e que muitas vezes lhes custam a vida, de forma que para muitos deles nunca se concretizam os “cruzados eus", que todos desejariam alcançar:

"No centro do romance está um grupo de personagens, a maioria dos quais é constituída de muçulmanos britânicos, ou de pessoas não particularmente religiosas, de origem islâmica, lutando precisamente com o mesmo tipo de problemas que têm surgido em torno do livro, problemas de hibridização e de guetização, de reconciliar o velho com o novo. Aquelas pessoas que se opõem violentamente ao romance, hoje, são de opinião de que a mistura entre diferentes culturas inevitavelmente enfraquecerá e destruirá sua própria cultura. Sou da opinião oposta. O livro Versos Satânicos celebra o hibridismo, a impureza, a mistura, a transformação, que vêm de novas e inesperadas combinações de seres humanos, culturas, idéias, políticas, filmes, músicas. O livro alegra-se com os cruzamentos e teme o absolutismo do Puro. Mélange, mistura, um pouco disso e um pouco daquilo, é dessa forma que o novo entra no mundo. É a grande possibilidade que a migração de massa dá ao mundo, e eu tenho tentado abraçá-la. O livro Versos Satânicos é a favor da mudança-por-fusão, da mudança-por-reunião. É uma canção de amor para nossos cruzados eus. ${ }^{66}$

66 Rushdie, Salman. Imaginary Homelands. Apud Hall, Stuart. A Identidade Cultural na Pós-modernidade. Rio de Janeiro: DP\&A Editora, 1999, pp. 91,92. 
$\mathrm{Na}$ coletânea intitulada Imaginary Homelands ${ }^{67}$, há textos cujo centro são relatos e discussões de cruéis ataques de intolerância cometidos contra imigrantes indianos, paquistaneses e africanos e das condições precárias em que vivem. Contra a visão conservadora de preservar-se a "pureza", Rushdie comenta que "a sociedade britânica e o pensamento britânico nunca se limparam da imundície do imperialismo." ${ }^{98}$

É importante assinalar que A Distant Shore trabalha sobre dados da realidade da emigração e da guerra na África (dados que podem ser constatados fora da literatura) e os elabora e reorganiza criativamente de modo a incitar o leitor a traçar um caminho recorrente de ida e volta: da ficção ao mundo contemporâneo e deste ao mundo da obra.

O leitor ocidental tem notícia da situação das prisões no mundo e poderia supor que uma prisão na América Latina estaria colocada num extremo, supondo-se uma linha contínua, e uma prisão na Inglaterra ou em outro país do primeiro mundo, num outro. Esse mesmo leitor talvez pouco saberia do que se passa em prisões de países africanos. O romance em questão dá a possibilidade de se aproximarem e compararem as situações impostas aos prisioneiros e, apesar de não se aprofundar em detalhes sobre o encarceramento na África, apenas aludindo à tortura de Bright, o que permite que se verifique, como possível ligação através da fábula, é que o prisioneiro Said, cheio de ilusões de melhorias de vida, morre vomitando, ignorado na prisão inglesa, e seu companheiro de cela, o africano que sobreviveu ao tratamento desumano ("primitivo"?), disseminado nos combates de sua África natal, sobreviverá também ao tratamento de difícil qualificação que recebe no Velho Mundo.

No mundo da realidade é certo que formas da globalização podem ser encontradas nas "prisões terceirizadas" e na aplicação de tortura, de maneira que os responsáveis possam sempre alegar ignorância do que se passa nelas, embora não se furtem a condecorar seus representantes, agentes designados para o trabalho sujo, conforme retratado no recente filmedocumentário, "Ghosts of Abu Ghraib" ${ }^{69}$, por depoimentos e confissões de jovens soldados americanos, e de ex-prisioneiros iraquianos, e filmes de reportagens da época, mostrando, por exemplo, Donald Rumsfeld negando ter conhecimento das "irregularidades" cometidas na prisão.

No romance, o período passado por Bright na prisão africana pode ser comparado à

67 Rushdie, Salman. "An Unimportant Fire" e "The New Empire Within Britain”.In: Imaginary Homelands: Essays and Criticism 1981-1991. London: Granta Books and Penguin Books, 1991, pp 120-148.

68 Idem, ibidem. p. 121. Acima traduzido por mim. No original: "British society, British thought has never been cleansed of the filth of imperialism."

69 "Ghosts of Abu Ghraib", documentário dirigido por Rory Kennedy, 2006. Moxie Firecracker. 
experiência de Gabriel na prisão do primeiro mundo. Obviamente não se cogita de piolhos, penicos compartilhados, colchões úmidos e arroz mal cozido, mas estamos longe do que se chamaria adequadamente de "civilização". Na prisão inglesa, o presidiário iraquiano vomita sangue e a limpeza é feita pelo presidiário africano, Gabriel, atendendo à sugestão do guarda, que lhe fornece toalhas de papel para a tarefa. O fato de o africano ter de limpar a sujeira pela qual não é responsável pode, indiretamente, remeter à lembrança de uma das formas em que foi utilizado o trabalho escravo, algumas das quais, transformadas em alguns aspectos e sob novas roupagens, deixaram herança visível na sociedade atual. Em vão Gabriel pede ao guarda socorro médico para Said. Sim, há um médico responsável e ele acaba comparecendo à cela, mas só quando já é tarde demais para se tentar curar a doença do iraquiano. O médico não vem prestar socorro: vem cumprir uma função burocrática, assim como o guarda cumpre apenas um papel institucional de fachada - nenhum dos dois desempenha o trabalho que deveria fazer, que seria o de estancar o processo da doença no caso do primeiro, e de não só vigiar os presos mas garantir a sua integridade física e psíquica, no do outro. Ao invés disso, os dois se unem num papel semelhante ao de torturadores, pois o nome daquilo a que submetem Gabriel é "tortura", apesar de se apresentar como forma despersonalizada e racionalizada de "solução", modo ao gosto do mundo dito civilizado. Por três dias o iraquiano passa muito mal e Gabriel pede ajuda ao guarda noturno e ao diurno, pois as horas passam, nada é feito, e Gabriel, ao ver o amigo morto, “... se recolhe ao canto mais distante possível da cela, encolhe o corpo como um novelo e escorrega ao chão."70 (DS,81).Mais adiante, ao mesmo tempo em que o guarda e o médico agarram Gabriel pelos membros, prendem-no na cama inferior do beliche e aplicam-lhe uma injeção que o deixa inconsciente toda a noite e o dia seguinte, travam entre si uma conversa amena em que se referem tanto à história do imigrante em frases sumárias e preconceituosas, quanto às próprias reclamações a respeito da falta de investimentos do Estado em suas áreas, aos cortes recentes, que afetariam o seu trabalho. A simplicidade e a aparente ingenuidade do diálogo chocam-se com as ações narradas. Há uma conversação que parece bastante inócua e controlada, mas que se presentifica simultaneamente à narração da reação de Gabriel, trecho repleto de verbos que denotam movimentos físicos de luta e desespero, de não aceitação da subjugação de que é feito objeto. Vejam-se dois exemplos de diálogos durante os momentos em que imobilizam o presidiário:

70 No original : "[...]Gabriel retreats to the furthest corner of the cell and huddles his body into a tight ball. He slides to the floor." 
“_ Por que ele está aqui?

-- Nem queira saber.

-- Então não é imigrante ilegal?

--Ah, é sim, mas isso é só parte da história.” (DS,82)

$[\ldots]$

“O médico arremata o nó final com força e se afasta. Veste novamente o casaco.

--Eles não devem demorar muito para recolher o corpo. Mas nunca se sabe ao certo.

Apavorado, Gabriel observa os movimentos do médico, que abre a maleta e dela

retira uma seringa e uma agulha comprida.

--Nem me fale. É por causa dos cortes, não é?

--Não há ambulâncias suficientes. Em alguns bairros estão utilizando carros particulares.

O médico se senta na beirada da cama estreita e olha para Gabriel.

--Não vai doer, mas você vai sentir algo como um leve arranhão."71 (DS,83)

Em primeiro lugar, vê-se a curiosidade do médico quanto ao grau de criminalidade de Gabriel, juntamente com a atitude do guarda que, peremptoriamente, como um juiz, dá o veredito sobre o prisioneiro, insinuando a gravidade do crime. É uma passagem em que o hiato de informação joga com os possíveis e variados pré-julgamentos e preconceitos do leitor, que fica também com a suspeita de que haja uma acusação muito séria pesando sobre a cabeça do africano, algo bem pior do que a entrada clandestina no país.

Assim, a humilhação sofrida por Gabriel na prisão inglesa, relatada no início do segmento, se dispõe na narrativa para possível paralelismo com a degradação sofrida por Bright na prisão africana, mencionada bem adiante. Por muito que lute e enfrente as provações que se apresentam, quer seja em vários espaços na Inglaterra (na prisão, em Londres, no condomínio no norte) ou em outros tantos, no país de origem (na cidade como office boy, ignorado por todos, nos combates como soldado e major em vários vilarejos e territórios, e ainda no percurso até a Inglaterra, ajudando o tio a liderar outros emigrantes), Gabriel não encontra verdadeiro refúgio em lugar algum; bem ao contrário, está constantemente enfrentando situações que o expulsam de um lugar a outro, quase sem trégua. Gabriel mantém-se firme face aos obstáculos; a sua atuação é a de agir e lutar, mas mantendo-

71 " 'What's he in here for?'

'You don't want to know.'

'He's not an illegal then?'

'Oh, he's that all right, but that's only half the problem."' (DS,82) $[\ldots]$

"The doctor pulls his final knot tight and then takes a step back. He begins to slip his jacket back on.

'They should be here for the body before too long. But who knows.'

A terrified Gabriel watches as the doctor opens his bag and pulls out a syringe and long needle.

'Don't tell me', says the warder. 'Cutbacks, right?'

'There's just not enough ambulances. In some burroughs they're using private cars.'

The doctor sits on the edge of the narrow bed and focuses on Gabriel.

'This won't hurt, but you will feel a slight scratch.' (DS,83) 
se reservado e quieto a maior parte das vezes. Considerando-se o volume das páginas que se referem a ele, são muito poucas as passagens em que participa ativamente sob a forma de diálogo. Quando o faz, em geral, é para responder laconicamente a perguntas de interlocutores; raramente inicia qualquer conversa. Obviamente, muitas são as situações em que é interpelado com desconfiança, tratado como ser de segunda categoria, a quem não é dada a oportunidade de participação genuína em travar qualquer troca positiva em uma conversa. A propósito, vem à memória o ótimo título de texto escrito por Gayatri Spivak, em relação a outro contexto de opressão, o da mulher na Índia : "Can the subaltern speak?"72. Há exceções já mencionadas, de conversas com a Sra. Anderson e com Dorothy, mas são em número reduzido. Como vimos anteriormente, em relação à primeira, relatou-se ao leitor, através de negações, aquilo que ficou reprimido na vontade de Gabriel e não foi compartilhado com a idosa. Com a segunda, houve maior aproximação, mas foram várias as situações de pensamentos que não se externalizaram, algumas idéias sugeridas em discurso indireto livre, outras silenciadas, também pelo mesmo recurso, e outras ainda que foram causa de mal-entendidos entre as personagens. O preconceito penetra como parte ativa do subtexto de uma conversa entre Dorothy e Gabriel, em uma ocasião de certa importância para o conhecimento dos dois, em que Dorothy entra pela primeira vez na casa de Gabriel/Solomon para uma breve visita, de passagem ao voltar das compras. O que seria apenas troca de amenidades entre pessoas que pouco se conhecem enquanto tomam café, revela-se uma conversa entrecortada, com alusões que não se explicitam logo e um mal-estar crescente. Desta vez, Solomon toma a dianteira e faz uma série de perguntas a Dorothy a respeito da cidade, do modo de pensar dos moradores, principalmente daqueles preconceituosos que lhe enviam cartas que, ao que tudo indica, contêm agressões, impropérios e ameaças. É uma cena de cerca de quatro páginas, construída de forma a acentuar a participação do leitor: Solomon se mostra exasperado com as cartas; Dorothy demora muito a compreender que tipo de cartas são e também se sente parcialmente acusada, como se estivesse sendo responsabilizada pelas agressões ali contidas. Pouco a pouco, ela vai se inteirar do que está em jogo, se sensibiliza com o outro e, por fim, um tanto tardiamente, repensa o problema racial em seu meio:

\footnotetext{
"Solomon aponta para o monte de cartas. - Estamos na Inglaterra. Em que tipo de lugar vim parar? Você pode me explicar?

-- Não entendo o que você quer dizer.

--Você gosta daqui? - Solomon faz a pergunta com a voz repentinamente alterada pela forte
}

72 Spivak, Gayatri. "Can the subaltern speak? Speculations on widow sacrifice”. Wedge 7/8, winter/spring, 1985. 
emoção.

Olho para Solomon, mas não compreendo. Sinto como se ele estivesse me culpando por alguma coisa. $^{73}$ (DS, 41)

A dificuldade de entendimento se encrava ali, alimentada pelo questionamento não muito claro e pelas respostas esquivas de falta de compreensão, embora aquilo a que as personagens aspirem seja uma comunicação sem percalços ou entraves. Durante boa parte da cena não se fala do conteúdo das cartas, mas a presença delas na casa de Solomon e o ódio racial que carregam, ao menos a princípio, parecem contaminar os participantes e ameaçar a amizade:

“--Você quer que eu as leia, é isso?

Solomon ri e não diz nada. Percebo que sofre e observo-o um pouco e decido que devo ir. Levanto-me e ele faz o mesmo. É constrangedor para nós dois, mas acho que o relacionamento não se rompeu de modo algum[...]." ${ }^{, 74}$ (DS,41)

A cena é descrita sem que nunca se especifique sequer uma das palavras escritas nas cartas, mas no final mencionam-se as lâminas coladas de propósito para cortar as mãos de quem as recebesse. Propositadamente, a cena focaliza a força do efeito do conteúdo dessas cartas sobre cada um dos protagonistas e sobre a relação entre os dois. Sem dúvida, mostra também que não é preciso que se revele o conteúdo delas, basta a alusão, pois qualquer leitor do ocidente, e até mais prontamente do que Dorothy, sabe do que se trata. A experiência de entrar em contato com o preconceito contra o africano faz que Dorothy repense o preconceito em sua família:

\footnotetext{
"Não sou ingênua. Digo isso a mim mesma. Sussurro outra vez. Não sou ingênua. Já me enredei nessas discussões no passado. Com meu pai e minha mãe, para começar, nenhum dos quais gostava de gente de cor. Meu pai dizia que via a gente de cor como uma ameaça à nossa identidade inglesa. Achava também que os galeses eram cheios de cretinices sentimentais, que os escoceses eram avarentos e choramingões irremediáveis e que deviam se manter lá do outro lado da muralha de Adriano, que os irlandeses eram católicos bêbados e violentos . Para ele ser inglês era mais importante do que ser britânico e ser inglês significava não haver gente de cor. Ele não dava maior atenção ao que eu dizia, assim como faziam os outros professores na escola, que também detestavam gente de cor. Quando havia outras pessoas por perto repetiam a cantilena sobre como eles não se adaptavam ao nosso sistema escolar, mas quando estávamos só entre nós,
}

73 No original: "Solomon points to the pile of letters. 'This is England. What kind of a place did I come to? Can you tell me that?'

'I don't know what you mean.'

'Do you like it here?' asks Solomon, his voice suddenly impassioned.

I look at Solomon, but I really don't understand. I feel as though he's blaming me for something."(DS,41)

74 'Do you want me to read them, is that it?'

Solomon laughs now, but he doesn't say anything. I realise that he has been hurt, and I watch him for a while and then decide that I should leave. As I stand up he also gets to his feet. It's awkward for both of us, but I don't think the relationship is in any way broken. (...)' (DS,41) 
era sempre 'negrinhos safados'. Sei que é o que as pessoas pensam. Não sou ingênua, mas por que o ódio contra Solomon, que não fala com ninguém? Que lava o próprio carro? Que não fez nada. O que essas pessoas pretendem alcançar? Quem de fato são essas pessoas? São as mesmas que escrevem para os jornais reclamando do peso das novas moedas e do fato de as cabines telefônicas não serem mais vermelhas? Conheço essa gente? Sento-me no ônibus do lado delas? $(\ldots)^{75}(\mathrm{DS}, 43)$

No final da visita, as reiteradas perguntas de Dorothy marcam o inconformismo com a atitude irracional e racista dos moradores de Stoneleigh e Weston:

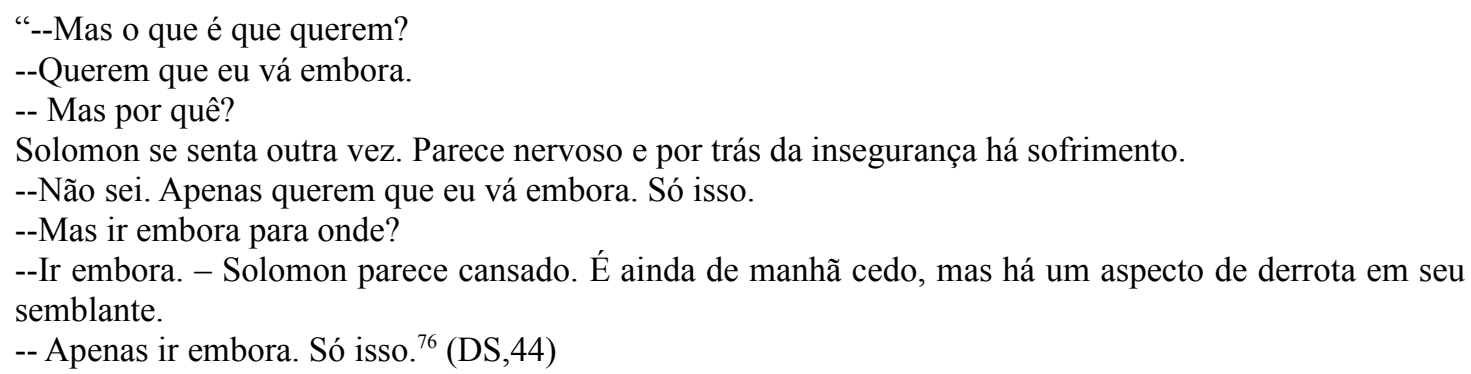

Adiante na leitura, quando se acrescentarem a essa cena outros complementos, tudo o que acarretou o percurso de Solomon para chegar a Weston, assunto focalizado no segundo segmento, é que será possível ter uma melhor visão do peso do preconceito na vida cotidiana retratada, e maior entendimento do que "apenas ir embora" pode significar para alguém cuja experiência vivida não parece mostrar a possibilidade de um lugar em que haja sossego num mundo alardeado como "sem fronteiras".

Outra cena, cronologicamente bem anterior à mencionada acima, colocada no penúltimo segmento, aborda a reação de alguns moradores preconceituosos que marcam com

75 “'I'm not naïve.' I say this to myself. I whisper it under my breath. I'm not naïve. I've got stuck into these arguments in the past. With Mum and Dad, for starters, both of whom disliked coloureds. Dad told me that he regarded coloureds as a challenge to our English identity. He believed that the Welsh were full of sentimental stupidity, that the Scots were helplessly mean and mopish and they should keep to their own side of Hadrian's wall, and that the Irish were violent, Catholic drunks. For him, being English was more important than being British, and being English meant no coloureds. He would no more listen to me than would the teachers at school, who also hated coloureds. When people were around, they'd go on about them not really adapting well to our school system, but in private they were always 'cheeky little niggers'. I know this is what people think, I'm not naïve, but why the hatred towards Solomon, who doesn't talk to anybody? Who washes his car. Who hasn't done anything. What do these people hope to achieve? In fact, who are these people? Are they the same people who write letters to the paper complaining about the new coins being too bulky, and the fact that telephone kiosks are no longer red? Do I know these people? Do I sit on the bus with them? (...)" (DS,43)

76 "But what do they want?

"They want me to go away."

"But why?"

Solomon sits back in the chair now. He seems nervous ,but behind his uncertainty there is hurt.

"I do not know. They just want me to go. That is all."

"But go where? I don't understand."

"Away." Solomon looks tired. It's still early in the morning but there is an aspect of defeat about his demeanour. 'Just away. That is all."'(DS,44) 
pichações ofensivas a fachada da casa do casal Anderson, anfitriões de Gabriel/Solomon, logo que este chega ao norte do país. Mais uma vez não se especificam as palavras utilizadas nessa forma de violência racial. Mais uma vez a utilização da alusão à ofensa e o registro das reações por parte das personagens, sem que se repitam as palavras dos pichadores, tudo isso se articula para interpelar o leitor, suas crenças e sua posição face à questão da imigração. Nessa passagem, em que o sr. Anderson dá uma explicação plausível para o ponto de vista dos cidadãos nativos da Grã-Bretanha, Solomon não chega a exteriorizar os seus pensamentos claramente através do desenvolvimento de um discurso que seria possível, mas tampouco mantém a forma lacônica de uma presença pesada, cheia de significados ocultos como em outros momentos. Expressa-se através de uma pergunta simples que ressoa para o leitor: como o preconceito entra na mentalidade das pessoas?

\begin{abstract}
-- Solomon, a primeira linha de defesa é o preconceito. Uma vez que você a ultrapasse, sempre haverá um pequeno canto onde possa viver e ser aquilo ou a pessoa que quer ser. Mas você tem de passar por essa primeira linha e as coisas não estão ficando fáceis. Há um número enorme de imigrantes e o sistema está arreando a ponto de se romper. Por exemplo, é especialmente complicado se você quer dar entrada em um dos nossos hospitais. As pessoas estão aborrecidas. Veja, Solomon. O caso é que esta não é uma ilha muito grande e não temos tanto espaço assim. As pessoas acham que outros países deveriam ficar com vocês primeiro, porque nós já fizemos a nossa parte. - Parou de falar e olhou para o outro lado. - Sinto muito, Solomon, mas é assim que algumas pessoas pensam. Que vocês só querem levar uma vida fácil, ou que vocês têm filhos demais. Acham que vocês não querem trabalhar. Essas idéias estão na cabeça delas e as deixam malucas.
\end{abstract}

--Quem as pôs lá?[...]

--Não sei. Realmente não sei. ${ }^{77}$ (DS,289)

Interessante será verificar outra visão, não tão diferente, do problema da imigração, conforme a da personagem Michael, trabalhador simples, de origem irlandesa, que se mostra parcialmente compreensivo quanto às dificuldades dos refugiados de guerra ou por questões políticas, mas impaciente quanto aos demais, aos que vêm procurar melhores oportunidades de vida:

77'Solomon, the first line of defence is prejudice. Once you get past that, there'll always be a little corner where you can live and be who or what you want to be. But you've got to get past that first line, and things are not getting any easier. There's an awful lot of you, and the system's already creaking up to breaking point. I mean, things are particularly bad if you want to get into one of our hospitals. People are upset.' [...]

'You see, Solomon, it's just that this isn't a very big island and we don't have that much room. People think that other countries should take you first because we've done our bit.' He paused and looked away. ' I'm sorry, Solomon, but some folk think these things. That you just want an easy living, or that you have too many children. They think that you don't really want to work. It's in their heads and it makes them mad.'

'Who put it there?' [...]

'I don't know, Solomon. I really don't know.'(DS,289) 
Olhe, nossa mãe me contou o que aconteceu, mas você tem que compreender que algumas pessoas provocam essas situações contra si próprias. Sabe, atualmente acontece principalmente com esses tipos indianos. - Mike fez uma pausa, suspirou e voltou a olhar para mim. Sou tradicionalista, Solomon. Quero peixe com batatas fritas e não batatas fritas com curry. Não tenho preconceito contra eles, mas daqui a pouco estaremos vivendo num país estrangeiro, a não ser que alguém ponha um basta em toda essa imigração. Esses indianos ainda obrigam as mulheres a segui-los a alguns passos de distância, e eles têm os seus templos e mesquitas e os açougues em cujos porões abatem os animais e fazem sei lá o quê com o sangue. Entende? Eles são camponeses. Vêm da roça e a maioria nunca viu uma válvula de descarga ou um interruptor de luz. É demais para eles. E para nós também. Devia haver algum tipo de treinamento ou eles deviam voltar para o lugar de onde vieram. É esse tipo de gente que faz com que outros tomem atitudes erradas e façam o que fizeram com a fachada da casa. Não estou dizendo que estão certos, porque não estão. Mas eu viajo muito pelas estradas e vejo bem como se sentem as pessoas, melhor do que o modo como vêem os da velha geração. Está por toda a parte. - Mike parou de falar e me encarou com um olhar de preocupação. - Sabe, a sua situação é outra. Você está fugindo da opressão e é diferente. Existem procedimentos para esses casos no nosso país. Quero dizer, você trabalha. Não é um aproveitador. Mas as pessoas não sabem disso e aí as coisas acontecem. - Fez outra pausa. - Você sabe do que eu estou falando, não é, Solomon? - Olhei para Mike e concordei com um gesto. Sabia do que ele estava falando. Eu compreendia." ${ }^{, 78}$ (DS,290,291)

Note-se que as últimas três frases mesclam o discurso do narrador, que nesse outro segmento é o protagonista, com a função de interlocutor da personagem que estava com a palavra, Mike. Pela brevidade - 'Sabia do que ele estava falando. Eu compreendia.' --, acentua-se o fosso entre as posições que as personagens ocupam.

Resta ao leitor pensar sobre a questão da imigração e imaginar de que forma poderia entendê-la um africano que tivesse passado por todas as agruras até chegar ao interior do país próspero. O que a narrativa indica é que o que Solomon de fato é forçado a entender é o corte que se operou na sua história, o afastamento de suas raízes, o peso de ter nas costas a morte de Felix e de outros durante a guerra, a desterritorialização, o não-pertencimento a parte alguma, a necessidade repetida de partir de onde estiver, a percepção da inexistência de laços que o estabilizem em algum lugar na Inglaterra, a dificuldade de se fazer conhecido e compreendido

\footnotetext{
78 " 'Look, Mum told me what happened, but you've got to understand that some people bring things on themselves, you know. I mean, these days, particularly the Indian types.' Mike stopped and sighed, and then he looked at me. 'I'm an old traditionalist, Solomon. I want fish and chips, not curry and chips. I'm not prejudiced, but we'll soon be living in a foreign country unless somebody puts an end to all this immigration. These Indians, they still make their women trail after them, and they have their mosques and temples, and their butcher shops where they kill animals in the basement and do whatever they do with the blood. I mean, they're peasants. They come from the countryside and most of them have never seen a flush toilet or a light switch. It's too much for them. And for us. There ought to be some training or they should go back. It's these kinds of people that cause others to have bad attitudes and to do things like they've done to Mum's wall. I'm not saying they're right, because they're not. But I drive around a lot, and I see how people feel, more than what the old folk does. It's everywhere.' Mike stopped talking and he stared at me, but with a worried look on his face. 'You see, you're in a different situation, Solomon. You're escaping oppression and that's different. We've got procedures for that. I mean, you're working. You're no scrounger. But they don't know that, and so that's what happens.' Mike paused. 'You do know what I'm saying, don't you, Solomon?' I looked at Mike and nodded. I knew what he was saying. I understood him.” (DS,290,291)
} 
pelos outros, quer sejam os britânicos por nascimento e tradição, quer sejam os imigrados de outras origens:

“[...]Era abençoado por estar na Inglaterra, mas esta vida não tinha nenhuma relação com a que eu conhecera em meu próprio país e conseqüentemente, a sensação era de que a minha nova família só conhecia uma pequena parte de mim. Na verdade, apenas uma metade de mim estava viva e funcionando. Tinha tentado conversar com os caribenhos que passavam o tempo na rua em frente ao Sonja's, restaurante em que se podia comprar comida caribenha, com seus penteados rastafari e as latas de cerveja na mão, mas não eram simpáticos e com freqüência viravam a cara ou gritavam comigo e agiam como bêbados. E bem antes disso, aprendera que não fazia sentido tentar entabular conversa com os indianos e com os paquistaneses porque eles eram piores do que alguns dos ingleses. Sentado à mesa do restaurante, olhando para o sr. e a sra. Anderson, disse-lhes que eu não sabia o que ia fazer agora que eu tinha "escolha". Me tornar menos solitário, talvez? Mas de repente me ocorreu o que poderia haver sob a pergunta do sr. Anderson, e me senti idiota. Agora que eu não me encontrava mais em situação ilegal, queriam que eu saísse da casa deles e arrumasse outro lugar para viver. Tinham cumprido a sua tarefa. Talvez tivessem achado outra pessoa para morar com eles. [...]"79(DS,292)

Solomon passa um ano hospedado como pensionista na casa dos Anderson, trabalha em construções como ajudante do sr. Anderson até que, pelo empenho da sra. Anderson, consegue os documentos que legalizam a sua situação no país e permitem que obtenha trabalho remunerado. Não é junto de caribenhos, paquistaneses ou indianos que Solomon se dá a conhecer. As várias iniciativas tomadas pela personagem visando à comunicação com os outros só surtem efeito maior em relação a Dorothy, que não pode deixar de ser vista como componente de uma sociedade inglesa tradicional, pertencente a uma geração de formação social bem diversa e anterior aos anos do governo Thatcher.

Por ter ligação com o que se esboça na ficção nesse segmento e em breves momentos em outros, parece relevante a esta altura fazer-se referência a peculiaridades do movimento social contra a discriminação racial no período seguinte às décadas de 1960 e 1970, época que passou a contar com a atuação de jovens negros, filhos da primeira geração de imigrantes do Caribe e da África. Nascidos na Grã-Bretanha e ansiosos por mudanças positivas na

79“[...] I was blessed to be in England, but this life bore no relationship to the one I had known in my own country, and as a consequence, i felt as though my new family knew only one small part of me. In truth only one half of me was alive and functioning. I had tried to talk to the few West Indian people I saw standing on the streets outside Sonja's Caribbean Takeaway with their dreadlocks and their cans of beer, but they were not friendly and they would often look to the other way or shout at me and behave like drunken people. And I had long ago learned that there was little point in attempting conversation with the Indians or Pakistanis, for they were worse than some of the English people. I sat in the fish restaurant and looked at Mr and Mrs Anderson and told them that I did not know what I would do now that I had 'choice'. Become less lonely? That was all I hoped for. But then it suddenly occurred to me what Mr Anderson might be suggesting, and I felt stupid. Now that I was legal, they wanted me to leave their home and find somewhere else to live. Their task was complete. Perhaps they had discovered another person to live with them? [...]" (DS,292) 
sociedade, utilizaram o slogan "Estamos aqui para ficar", pois não se tratava mais de imigrantes como muitos de seus pais, que eram levados a ver a si próprios como "hóspedes temporários do governo de Sua Majestade". Esses jovens não tinham ido à Inglaterra para trabalhar e para algum dia "voltar para casa" no Caribe ou na África. Vejam-se as palavras de Brinsley Ford, do grupo de música Aswad, em entrevista concedida a Kwesi Owusu: "Nascemos aqui e deveríamos ter recebido todos os benefícios que os nossos colegas de escola brancos recebiam, mas não era assim. Não havia emprego, havia condições de moradia ruins e muita pressão nas ruas. $"{ }^{80}$

Historicamente, não se deu a solidificação da união de forças tão esperada nos anos de 1980 entre os imigrantes não-brancos, oriundos de diversos pontos do antigo império britânico no Caribe, na África e na Ásia. É fato que houve a formação importante de associações profissionais ou políticas tais como a Black Media Workers Association, a Organization of Women of African and Asian Descent (OWAAD), o Britain Defence Committee, Southhall Black Sisters, Creation for Liberation, African Liberation Committee, Black Action for the Liberation of South Africa (BALSA), Black Radical Third World Book Fair, e Campaign Against Racism and Fascism (CARF), dentre outras ${ }^{81}$. O desenvolvimento mais evidente deu-se no campo cultural, tanto assim que a década de 1980 ficou conhecida como o segundo Renascimento Negro na Grã-Bretanha no período após a Segunda Guerra. Todavia, nos anos de 1990 houve cortes drásticos nos subsídios governamentais e "estilhaçouse em várias direções a complexa constelação de forças artísticas e ideológicas mobilizadas no nível político (com algum esforço), para que se enfrentassem as políticas culturais e discursos anglocêntricos dominantes ${ }^{82}$. Em meados dos anos 90 houve um distanciamento dos grandes temas globalizantes da década precedente, como a identidade negra britânica, a arte negra, a luta, o combate ao racismo, etc., temas que pareciam indicar uma certa prontidão para que se abraçassem alianças políticas acima das diferenças de nacionalidade e etnicidade. Foi significativo o colapso da união política entre africanos, caribenhos e asiáticos.

Segundo o pensador e ativista negro A. Sivanandan, os levantes raciais de $1981 \mathrm{em}$ Brixton e de 1985 em Broadwater Farm foram principalmente "movimentos de revolta dos jovens contra os cortes drásticos impostos por M. Thatcher”. Esses distúrbios fizeram que o governo, com medo de que ocorresse na Inglaterra os tipos de problemas comuns nos Estados

80 Owusu, Kwesi. Black British Culture \& Society. Londres: Routledge, 2000, p9.

81 Idem, ibidem, p. 6.

82 Idem, ibidem, p. 11. 
Unidos, determinasse um estudo geral da situação. Lord Scarman, responsável pelo relatório final da pesquisa, afirmou que a causa dos problemas eram o preconceito e a desigualdade raciais em geral, e não alguma forma de racismo advinda das instituições ou do governo. $\mathrm{O}$ governo achou que a solução seria promover "curas étnicas" e igualdade de oportunidades. A essa altura o movimento do multiculturalismo já havia afetado a unidade negra e com isso a fragmentação se acentuou. Em organizações como o Conselho da Grande Londres (Greater London Council), que seguiram a linha de propostas de Scarman a respeito das desigualdades, disponibilizaram-se recursos conforme a etnia a todos os tipos de grupos que, a partir de então, puseram-se a brigar entre si para a obtenção de recursos e de poder. Os centros de relações raciais levaram os programas de igualdade de oportunidades (com as quotas implícitas e um esquema de monitoração étnica) às delegacias locais e aos departamentos do governo. Na verdade, ainda segundo depoimento de A. Sivanandan, as políticas negras foram transferidas das ruas para as prefeituras. A luta propriamente, que afetava toda uma comunidade e que era uma luta contra o sistema e contra o racismo, transformou-se numa luta de indivíduos por emprego, poder e "um lugar sob o sol étnico". Quem se rebelou contra as dificuldades em suas vidas foram os jovens das áreas degradadas dos centros urbanos, mas os que se beneficiaram foram os negros de classe média, que tiraram proveito das campanhas de igualdade de oportunidades e de programas étnicos para subirem socialmente. Os jovens foram deixados em uma situação pior, privados dos saberes e conhecimentos negros a que anteriormente tinham alcance ${ }^{83}$.

A. Sivanandan, que foi diretor do Instituto de Relações Raciais e trabalhou ativamente no movimento negro e em campanhas contra o racismo por mais de três décadas, concorda com Stuart Hall, sociólogo e estudioso das identidades raciais, quando este afirma que “diferentemente da década anterior [a de 1990] na qual os afro-caribenhos e os asiáticos eram vistos pela classe dominante como tão semelhantes que podiam ser subsumidos e mobilizados em uma única categoria política (...), hoje isso não é mais assim" ${ }^{84}$. Sivanandan diz que não há mais condições objetivas para uma política negra e para a união entre afro-caribenhos e asiáticos, e encara as idéias do multiculturalismo como responsáveis pela quebra dessa união e por substituí-la por ilhas culturais e rixas entre grupos de diferentes nacionalidades: “...os caribenhos contra os asiáticos nos conjuntos habitacionais, os sikhs contra os muçulmanos em

83 Owusu, Kwesi. "The struggle for a radical black political culture - An interview with A. Sivanandan". In: Owusu, Kwesi (org.) Black British Culture \& Society. Londres: Routledge, 2000, pp. 416-424.

84 Idem, ibidem, p. 423. 
Southhall e Slough, e os africanos contra os afro-caribenhos nos programas oferecidos pelas prefeituras." ${ }^{\prime 2}$. Sivanandan vê esses componentes como graves aspectos da segmentação racial e discorda do argumento teórico feito por Stuart Hall a respeito das "linhas de frente internas que intersectam a identidade" ${ }^{\nexists 6}$. Afirma, por fim, que o reconhecimento da existência da segmentação cultural não implica que se a aceite:

“[...]A segmentação cultural, tal como a divisão de classes sociais, sempre esteve presente, embora, é fato, seja mais profunda e mais complexa hoje em dia. Porém, por isso, faz ainda mais sentido combatê-la antes que se volte contra si mesma e se torne mais reacionária e desemboque em culturalismo, etnicidade e nacionalismo auto-contemplativo. A preocupação de Stuart Hall é com a identidade cultural e com a política cultural; a minha, é com a justiça racial e com uma política cultural que seja capaz de garantir justiça social, uma política cultural socialista. A política cultural tende a promover divisões culturais; a cultura política tende a atravessar essas divisões." ${ }^{87}$

Levando-se em conta as forças que se mobilizaram nos movimentos contra a discriminação racial e as diferentes posições e tendências, é possível ter-se melhor compreensão do terreno que se apresentaria a um africano refugiado de guerra num ambiente em que não há acolhida solidária por parte de outros grupos de imigrantes já anteriormente estabelecidos na Inglaterra, ainda mais porque muitas vezes competem entre si. Se, por um lado, Gabriel geralmente se depara com a animosidade dos brancos, encontra maior possibilidade de comunicação com as personagens femininas, não só ocidentais.

Além de Dorothy, cada uma das principais personagens femininas com quem Gabriel entra em contato, vêm de uma formação social diferente, de modo que o relacionar-se com cada uma abre uma esfera distinta e parcial numa constelação que é revelação de um novo mundo para o protagonista.

Ainda jovem, em sua terra natal, em trabalho subalterno numa repartição pública, Gabriel experimenta, por um lado, o sentimento de rejeição pelo preconceito social -- não lhe é permitido o uso do elevador, espaço restrito aos funcionários mais graduados; por outro lado, sente a atração exercida pelas funcionárias de aparência bem cuidada e dispendiosa. São 85 Idem, ibidem, p. 423. 86 Idem, ibidem, p. 423.

87 Idem, ibidem, p. 423. Acima traduzido por mim.No original: “[...]Cultural segmentation, like class segmentation, was always there - except that, yes, it is deeper and more complex today. But that is the more reason to fight it, before it becomes inward-looking and reactionary and recedes into culturalism and ethnicism and self-regarding nationalism. Stuart's preoccupation is with cultural identity and cultural politics, my preoccupation is with racial justice and a political culture that can deliver racial justice, a socialist political culture. Cultural politics tends to promote cultural segmentation, political culture attempts to cut across such segmentation." 
mulheres bem vestidas e perfumadas, pelas quais dinheiro e tempo são gastos para a transformação dos traços físicos e de origem racial, cabelos e cor da pele, para aproximação aos das mulheres brancas, com o intuito de se relacionarem de alguma forma com os homens corruptos do serviço público que poderiam lhes prometer algum benefício:

“[...]Eu sabia o nome de algumas dessas mulheres, mas mulheres como essas jamais seriam vistas comigo. Eram mercadorias numa loja e eu não tinha dinheiro.(...) Essas mulheres não me consideravam como homem. Um mensageiro de escritório não é um homem; eu era uma coisa a ser tolerada, uma criatura de camiseta e calças rasgadas não muito melhor do que as baratas que correm pelo chão fazendo barulho. O que é que eu sabia de Johnny Walker Black label? Se o ministro ou o funcionário público não tinham nada para eu entregar, então uma dessas mulheres me dispensava com um movimento de suas unhas vermelhas e eu, mais uma vez, ia-me juntar aos outros empregados que, agachados na rua, jogavam cartas e rolavam dados." (DS, 139)

Em cerca de vinte linhas faz-se o retrato de uma repartição pública de uma cidade no mundo subdesenvolvido, com a corrupção que a permeia em vários níveis, desde os desvios nos serviços que não são prestados, passando pela desumanização dos homens e mulheres que ali estão e que ali deveriam trabalhar, seres que, na narrativa, se qualificam metonimicamente, por adereços e acessórios - cabelos alisados, cosméticos branqueadores da tez, alfaiataria ocidental, grandes carros importados, muitas viagens ao exterior - até a deterioração que se vê em suas dependências - a escuridão nos poços das escadas, com degraus manchados cheirando a urina, cantos onde habitam ratos e baratas que passeiam pelos escritórios. Sem comentários, faz-se o esboço de uma forma de miséria urbana, de indignidade e torpeza, de deturpação do trabalho a serviço do público. Também sem comentários ou ironia, registra-se que a aspiração do jovem Gabriel era galgar uma posição como auxiliar de escritório dentro da repartição, vista como degrau superior à condição de office boy.

Outro tipo de miséria está descrita nas passagens em que se trata da viagem através dos continentes, mas mostra-se em sua acepção tradicional, freqüentemente associada à situação da África e do Terceiro Mundo - a miséria como extrema pobreza, como falta, como penúria, seca e desamparo. Significativamente, é nesse cenário árido e pobre que a figura do feminino resplandece na personagem da muçulmana Amma, que se solidifica como

88 No original: “[...]I knew the names of some of these women, but such women would never be seen with me. They were goods in a shop, but I had no money. (... these women did not consider me to be a man. A messenger clerk is not a man: I was a thing to be tolerated, a creature in a T-shirt and torn pants who was not much better than the cockroaches that skittered noisily across the floor. What did I know of Johnnie Walker Black Label? If the ministr or civil servant had nothing for me to take back down the rotten stairwell, then one of these women would dismiss me with a flourish of their red nails and I would once more join the other clerks who squattered in the street rolling dice or playing cards." [...](DS,139) 
elemento secundário, mas articulador de narração e descrição. Na maior parte do tempo de sua convivência com Gabriel, desde a África até a França, a personagem Amma recebe um valor especial: é definida principalmente por meio da descrição e por ter uma presença central na plasticidade de quadros sucintos, sugestivos de beatitude e beleza, vistos pelo fascínio que exercem sobre Gabriel. Única mulher viajando entre os emigrantes, seu gestual é registrado em poucas pinceladas, mas rigorosamente marcado pelo seu propósito determinado de assegurar a integridade e segurança do filho pequeno que carrega em cada fase da viagem ou de permanência nos acampamentos. De grandes olhos amendoados, com as dobras largas de suas vestes longas, posicionadas de muitas formas para acomodar o menino ao alimentá-lo, agasalhá-lo, mantê-lo adormecido em repouso sereno, Amma aproxima-se da figura mítica do feminino, do misterioso, da geração de vida e de sua manutenção e, como tal, de elo de possível acesso à sacralidade ${ }^{89}$. Tudo o que emana dessa personagem é exceção em relação aos espaços que atravessa. Contra as agruras por que passam, contra a rudeza que predomina nas relações do grupo de viajantes, contra o oportunismo dos inescrupulosos que lhe vendem a ilusão de um trecho de viagem em segurança até a Inglaterra, quando tudo indicaria a sua morte e a de seu filho, caso se atirassem sobre o trem em movimento, contra a revolta de Gabriel no intuito de recuperar o dinheiro pago àqueles agenciadores da morte, contra tudo isso, Amma se mantém firme na decisão de proteger a vida. Submete-se a perder o dinheiro porque sabe que o enfrentamento poria em risco sua vida e a de seu filho. A aceitação da injustiça não é novidade em sua experiência de muçulmana. Duplamente desrespeitada: primeiro, por ser vítima de estupro em sua terra e segundo, como conseqüência, por ser ostracizada pelos homens da família do marido que, provavelmente em conformidade com as leis Sharia, consideram-na impura (haram) para permanecer entre eles.

A esse respeito, para melhor compreensão da questão feminina em pontos do Oriente, vale a pena remetermo-nos a um artigo publicado há três anos, em que Salman Rushdie relata vários casos reais acontecidos com mulheres no Paquistão e na Índia. São casos que vieram a público porque as vítimas tiveram coragem de denunciar o crime, ao invés de se suicidarem como é costume, o que não lhes conferiu garantia de integridade ou direito de reparação. Num desses casos acontecidos no Paquistão, Rushdie aponta a hipocrisia do presidente Musharraf, que ao mesmo tempo se alia a governos do ocidente com um discurso de combate ao terrorismo e nada faz contra uma guerra de terror sexual, travada contra as 
cidadãs do país ${ }^{90}$. Ocorreu, por exemplo, que, no final de um processo, a médica Shazia Khalid recebeu tantas ameaças que quis abandonar o país, mas teve o passaporte confiscado para evitarem-se as repercussões contra o governo no exterior. Na Índia, a situação é também gravíssima, segundo Rushdie, pois há a anomalia decorrente da existência de um segundo sistema de leis, que atua paralelamente ao legal, sobre a vida de indianos muçulmanos. Nos anos de 1980, por exemplo, a Corte Suprema da Índia determinara que Sha Bano deveria receber pensão alimentícia em conseqüência de seu divórcio, mas, como a lei islâmica não reconhece esse direito, os ortodoxos islamitas protestaram veementemente contra a sentença, alegando tratar-se de infração da Lei sobre a Pessoa Muçulmana e logo criaram o Colegiado da Lei Muçulmana para Toda a Índia (All-India Muslim Law Board) para organizarem as forças de reação. O resultado foi a capitulação do governo, que logo promulgou uma lei segundo a qual se nega às mulheres muçulmanas o direito à pensão alimentícia. Nas palavras do escritor indiano:

A cultura do estupro existente na Índia e no Paquistão se origina em profundas anomalias sociais e advém da severidade imutável de um código moral baseado nos conceitos de honra e vergonha. É devido à crueldade desse código que as vítimas de estupro vão continuar a se suicidar, enforcando-se nos bosques e afogando-se nos rios. Demorará gerações para se mudar isso. Até que isso aconteça, a lei deve fazer o que pode.

\section{(...)}

... qualquer país que se proclame uma democracia laica e moderna precisa secularizar e unificar seu sistema legal e libertar a vida das mulheres, de uma vez por todas, do poder de instituições medievais... ${ }^{91}$

No romance, quando Gabriel e Amma voltam para o acampamento, malograda qualquer possibilidade de se atirarem sobre o trem em movimento com destino à Inglaterra, perdido o dinheiro que Amma pagara aos agenciadores, após a discussão com Gabriel e a

90 Rushdie, Salman. "Where is the Honour in this Vile Code that Condemns Women to Shame?" The Guardian, $30^{\text {th }}$ March, 2005.

91 Ibidem. Acima traduzido por mim. No original: "The culture of rape that exists in India and Pakistan arises from profound social anomalies, its origins lying in the unchanging harshness of a moral code based on the concepts of honour and shame. Thanks to that code's ruthlessness, raped women will go on hanging themselves in the woods and walking into rivers to drown themselves. It will take generations to change that. Meanwhile the law must do what it can.

(...)

....any country that claims to be a modern, secular democracy must secularise and unify its legal system, and take power over women's lives away, once and for all, from medievalist institutions." 
menção ao fato de ela se sentir inapta a retomar a vida como mulher junto de um homem devido ao trauma que sofrera, quando se dirigem para os seus lugares no fundo da barraca, são observados atentamente por muita gente nova que ali se estabeleceu durante a breve ausência do casal. Aqueles que eles reconheciam estavam agora mais para o fundo e não ousaram inquirir Amma ou Gabriel, "seus companheiros de semblante atormentado" (DS,131). Gabriel, porém, tem coragem de verbalizar a pergunta: "O que vai acontecer conosco?’(DS,131), que fica sem resposta, pois Amma se deita numa posição que indica a sua depressão, com as pernas encolhidas e as mãos unidas, presas entre os joelhos, o olhar voltado para o bebê ao seu lado, imobilizada num silêncio que faz que Gabriel desista e se renda à exaustão. No que se refere aos acontecimentos narrados é a última vez em que se vê Amma como personagem autônoma: aparece brevemente, como já se mencionou, figurando num sonho de Gabriel. Ao invés dela, que era a possibilidade de relação amorosa, de compartilhamento de intimidade e completude, Gabriel terá a companhia do africano Bright, jovem expansivo, barulhento e determinado. Amma vai procurar algum novo caminho para si na França, e assim se abre uma nova etapa na narrativa de viagem, etapa ainda mais arriscada para a integridade física do herói, e ainda mais árida e desoladora no que concerne o relacionamento com os outros. A crescente dificuldade da passagem para a última etapa da viagem se mostra paralela à crescente esterilidade dos relacionamentos que Gabriel consegue ter. Até a chegada e durante o período no acampamento em solo francês, a tristeza da condição de Gabriel é relativamente contrabalançada pelo vivo elo de ligação com essa mulher, que simboliza a beleza e a harmonia, e a quem vê como objeto de preocupações e consideração.

A primeira imagem de Amma não a separa da maternidade, do cuidado para com um outro, que é o filho e que aparece como parte dela, e está ligada a uma suavidade de atitude, totalmente incongruente com tudo o que há ao redor. No trem, a simples visão da cena de uma bela mãe com o bebê adormecido nas dobras das vestes estabelece uma comunhão entre mãe e filho, que vai além do efeito estético sobre o observador. Um dos efeitos é que Gabriel pensa imediatamente no futuro, no que irá fazer quando tiver alcançado a Inglaterra. Chega a expressar para o tio, no comando do grupo de viajantes, o incômodo com a presença de Amma: 
causando algum problema?

--Não, não. - Gabriel responde de pronto. -- Não sei o que pensar em relação à criança.

--Bom, a criança é problema seu?

--Claro que não.

Joshua responde rindo, em voz baixa: --Gabriel, essa mulher não estaria no meio de nós se não soubesse cuidar de si e de seu filho. Não se preocupe com ela. Já temos problemas nossos o suficiente.

-- Como assim?

-- Vamos só até Paris. Esse homens dizem que, se quisermos ir até a Inglaterra, teremos que fazer isso por nossa conta. (...) $(\mathrm{DS}, 105)^{92}$

A entrada de Bright marca o início de uma ligação que se forma entre sobreviventes: é forte, mas não propriamente de amizade; marcada por ambigüidades, já que Bright lhe salva a vida logo que chegam em terra firme, porém, logo o abandona ferido numa casa abandonada, o que acaba por comprometer a liberdade de Gabriel.

A pujança das qualidades masculinas da nova personagem, nem sempre utilizadas para o bem, como a agressividade, imediatez nas tomadas de decisões, liderança e carisma ao comandar um grupo, parecem provocar o esmaecimento do status de Gabriel, que é empurrado, pelas vicissitudes do percurso, para uma posição mais passiva e mais ligada à observação do que se passa ao seu redor. A relativa imobilidade imposta a Gabriel, resultado do ferimento na perna, vai permitir que examine com minúcia aspectos da vida no ocidente, principalmente os que vêm até ele através da personagem Denise. Abre-se uma nova e breve angulação no enunciado da narrativa, que se associa ao recurso do foco narrativo como traço dominante para que se trate de preconceitos e diferenças culturais.

Bem sabemos que não é correto compararmos aspectos de culturas diferentes de forma superficial, pois há complexidades que o observador fatalmente ignora na cultura que não é a sua. Entretanto, qualquer contato entre representantes de culturas diversas implica

92No original: "What is the woman doing among us?"

Joshua smiles. "My nephew, everybody is leaving to go to a better place. Is she causing problems?"

"No, no." Gabriel is quick to speak now. "I do not know what to think about the child."

"Well, is the child your problem?"

"Of course not."

Joshua chuckles under his breath.

"Gabriel, the woman would not be here among us if she did not know how to take care of herself and her child Do not worry about her. We have enough troubles of our own."

Gabriel turns to face his uncle. "What do you mean?"

"We are going only to Paris. These men say that if we wish to go to England then we will have to do so by ourselves....(DS,105) 
que se observem os costumes, diferenças e semelhanças, e que se façam avaliações e juízos comparativos. Assim, os diálogos entre Gabriel e Denise abrem ao leitor uma série de considerações que não ocorreriam de outra forma. Denise é a primeira pessoa do ocidente com quem Gabriel trava conhecimento. Na composição formal, é co-actante que interage com o protagonista num plano equivalente ao de Amma e de Bright. $\mathrm{Na}$ primeira vez em que conversa com Gabriel e Bright na casa abandonada, logo expressa certa condescendência de ocidental que tudo sabe, quando tece comentários a respeito dos nomes dos recém-chegados: “-- Gosto dos nomes de vocês. São tipo simples. Todo o mundo no país de vocês tem nomes simples?"93 (DS,153) Denise também dá a entender que já calcula o que os desconhecidos planejam fazer:

—Eu achava que vocês... o seu pessoal ...se entregavam à polícia. Não é o que vocês fazem para conseguir asilo como querem?

--É. Mas queremos ir para Londres antes . - Bright ergue os ombros. - Se fizermos isso aqui, eles podem nos pôr direto de volta no barco. $(\mathrm{DS}, 154,155)^{94}$

Na segunda ocasião em que Gabriel e Denise se encontram abre-se um fosso entre eles: a tagalerice derrisória da adolescente, a maneira como porta em seu corpo atarracado o uniforme curto da lanchonete onde trabalha, que Gabriel supõe ser uniforme de escola, o tom galhofeiro com que o interpela e com que se refere à conclusão a que chegou --de Bright tê-lo abandonado sem se explicar --, tudo o que vem dela se choca com a gravidade da condição de Gabriel: fisicamente, a dor do ferimento, o obstáculo que significa, a fome e sede extremas; mentalmente, o tormento de ter de lidar com a traição do amigo e seguir sozinho.

A narrativa não se detém absolutamente em qualificar essa nova provação que se impõe ao protagonista. Não há palavras contra Bright ou contra Denise. Ao invés, mantémse a onisciência de terceira pessoa, a face neutra e visão colada à perspectiva de Gabriel. Novamente, através da triangulação desenhada por meio da narrativa próxima da neutralidade, pelo laconismo do africano e a visão advinda do leitor, ressaltam-se as incongruências ali expostas ou sugeridas.

A reação de Gabriel é de, através do silêncio, se armar contra a vulgaridade que

93No original: “ I like your names. They're kind of simple. Does everybody in your country have simple names?" (DS, 153)

94No original: "I thought you lot turned yourself in to the police. Isn't that what you do to get your asylum?"

"Yes. But we wish to go to london first." Bright shrugs his shoulders. "If we do it here, they may put us

straight back on the boat."(DS,154,155) 
vem da adolescente. Mais uma vez, ecos que emanam da palavra "respeito", agora através do adjetivo derivado negativo, reverberam com sentido potencializado. Mais uma vez, o africano se vê desrespeitado:

\begin{abstract}
"Gabriel olha para outro lado e não para ela. Precisa de tempo para pensar, mas sente o olhar dela sobre si. Ela o encara e espera que lhe diga alguma coisa, mas Gabriel nada tem a dizer a essa menina desrespeitosa. Nem ao menos quer olhar para ela. Sente que Denise está a ponto de fazer mais uma pergunta e então fecha os olhos contra ela e a luz forte do sol, na tentativa de controlar a raiva." ${ }^{95}$ (DS, 161)
\end{abstract}

O desenvolvimento desse episódio só virá bem mais adiante na narrativa, posteriormente a uma parte final do entrecho, referente ao período da prisão de Gabriel, às sessões com os advogados e mesmo ao período inicial de liberdade em Londres. Quando a narrativa retoma a cena com Denise na casa abandonada no litoral, o leitor já estará ciente de que as acusações foram retiradas e de que a menina se recusou a testemunhar. $\mathrm{O}$ advogado mais experiente deixa claro que, sem a menina, não haveria causa judicial e Gabriel estaria livre para partir. Não se esclareceu exatamente a natureza da questão judicial. Só mais adiante se saberá que Denise fora instigada pelo pai alcoólatra a acusar o africano de estupro, a fim de obter indenização. De qualquer modo, na segunda parte do episódio com Denise, revertem-se os papéis. Aos poucos Gabriel toma ciência da negligência que permeia tudo na vida da adolescente: desde a aparência descuidada, o excesso de peso, o cabelo sujo, o uniforme curto demais e as maneiras grosseiras, até a história pregressa, o abandono pela mãe, o pai bêbado que vive do seguro-desemprego e lhe bate com freqüência, o namorado semelhante ao pai, a falta de apoio.

Com sua tagarelice, Denise continua a exibir sua displicência sem pudor: “Como é a África? Não é só selva e animais,né? Até aí, eu sei.”(DS,184). Denise pula de um assunto a outro, de uma situação grave para uma corriqueira, nivelando tudo num roldão. $\mathrm{O}$ narrador expõe a estranheza que essa superficialidade causa no estrangeiro:

“Gabriel não tem idéia de que modo deva participar dessa conversa, mas não quer constranger a menina com o seu silêncio.” (DS,185)

95 No original: Gabriel looks away from this girl. He needs time to think, but he can feel the girl's eyes upon him. She is staring at him and waiting for him to say something, but Gabriel has nothing to say to this disrespectful girl. He does not even wish to look upon her. Gabriel can sense that she is about to ask another question and so he closes his eyes against the girl, and the bright sunlight, in an attempt to control his anger. (DS, 161) 
(...)

Gabriel olha para a menina de uniforme em pé bem à sua frente, supondo que já seja uma mulher. Lembra-se de que na sua terra muitas meninas dessa idade já têm seus bebês e suas responsabilidades, e não xingam, nem falam mal dos pais, e jamais ficariam sozinhas com um homem dessa maneira. É difícil para Gabriel distinguir se essa menina é representativa de todas as meninas inglesas, mas embora continue a se sentir grato por ela ter-lhe trazido comida, não confia nela. $(\ldots)^{n 96}(\mathrm{DS}, 185)$

Há momentos fortuitos de humor, resultante da disparidade desses dois seres de culturas e percepções tão diferentes, que vão se modificando:

\footnotetext{
--Você não me contou nada de si. Tem mulher? E sabe cantar e dançar ou fazer esse tipo de coisa? Quer dizer, eu já vi gente como você dançando. É como se pusessem todos os problemas para fora pelo suor da dança. Como se estivessem em transe ou coisa assim, sacudindo a cabeça e o resto.

-- Não sei dançar ou cantar.(...)

-- Mas afinal, você tem mulher? (...)

Ela lhe pergunta coisas que não são da sua conta e ele se aborrece pelo fato de não ver que ele é um homem adulto e ela é apenas uma criança. Denise não espera pela resposta.

--Eu por mim, não gosto de famílias. Especialmente do meu pai.

Gabriel fica abalado pelo tom de melancolia que inunda a voz da menina. Denise abaixa o olhar e afasta os restos de peixe com batata. Diferentemente de Gabriel, não se dá ao trabalho de fechar bem o pacote. De repente, parece arrasada e Gabriel se sente compelido a salvá-la da situação.

-- Não tenho família, -- diz ele. - Todos foram mortos na guerra em minha terra. Mas estou aqui no seu país porque quero poder tomar conta dos meus filhos ainda não nascidos.

--Não entendi.

--Penso no futuro. Mas Deus poderia facilitar as coisas para todos nós, se tornasse possível ao meu povo marchar pelas ruas em paz. Lá na minha terra muitos continuam a sofrer. Ela levanta os olhos e o encara.

-- Queria que matassem o meu pai.(DS, 187) ${ }^{97}$
}

96 No original: "What's Africa like? It's not really jungle and animals, is it? I know that much." (SD,184)

(...)

Gabriel has no idea how to participate in this conversation, but he has no desire to embarrass the girl with his silence. (...)

Gabriel looks at the girl standing before him in her school uniform, imagining that she is already a woman.He reminds himself that in his country many girls of her age already have babies and responsibilities, and they do not swear, and are not abusive about their parents, and they would never sit alone with a man in this way. It is difficult for Gabriel to tell if this girl is typical of all English girls, but although he remains grateful to her for bringing him food, he still does not trust her. (...) (DS,185)

97No original: "You haven't told me anything about yourself. You got a wife? And can you sing or dance or do something like that? I mean. I've seen you lot dance, it's like you're sweating away all your problems. Like you are in a trance or something, shaking your head and everything.

"I cannot sing or dance.(...)

"Well, you got a wife then?"

She is asking him questions that do not concern her, and it troubles him that she cannot see that he is a grown man and she is merely a child. She does not wait for him to answer.

"Me, I don't like families. Especially my dad."

Gabriel is disquieted by the new tone of melancholy that floods this girl's voice. Denise lowers her eyes, and then she pushes the remains of her fish and chips to one side. Unlike Gabriel, she does not bother to wrap them up. Suddenly, she seems distressed, and Gabriel feels moved to rescue her.

"I do not have a family," says Gabriel. "They were all killed in the war in my country. But I am here in your country because I wish to be able to take care of my children who are as yet unborn." 
O humor vai-se modificando, passa para a vontade de compreender um pouco melhor o outro, de revelar também um pouco mais de si, e acaba-se por atingir um nível de percepção do sofrimento alheio, que os aproxima e, simultaneamente, mostra como ambos se sentem desalentados e faz que adormeçam. É um exíguo momento de comunhão entre seres bastante incompreensíveis um para o outro, num ambiente degradado, que em nada favorece a delicadeza, mas, no entanto, ela surge mesmo assim, embora seja por pouco tempo.

Denise diz não entender a fala de Solomon, mas a sua resposta, só aparentemente desconexa, traz a figura do pai à conversa e, de fato, acima das incongruências culturais entre os interlocutores o que está em pauta é a questão da paternidade e de um tipo de masculinidade a ser examinado. À medida que se aprofunda no conhecimento da história de Denise, o quadro revela-a como um ser à deriva, numa situação que poderia ser vista como muito próxima de uma espécie de "orfandade familiar e social", já que não pertence à pequena família tradicional burguesa da modernidade, nem a qualquer agrupamento da pósmodernidade. Na vida sob a globalização, o romance nos mostra que não houve a superação do patriarcado, conforme se esperaria na passagem para o terceiro milênio, mas sim a sua degeneração. Além da contradição já mencionada sobre o discurso existente favorável à globalização como mundo sem fronteira, liberalização de comércio e trabalho em contraste com a situação real dos emigrantes pobres e as barreiras de toda a espécie que enfrentam, está presente no embate entre Denise e Gabriel a justaposição de duas faces da miséria: por um lado o sofrimento da guerra civil na África que corta os sonhos de um homem bem preparado e ansioso por ter um família com todo o fardo que possa acarretar; por outro lado, a miséria do ocidente, que nem chega a promover qualquer sonho, pois a adolescente desvalorizada tem a mente embotada, acha-se enredada entre a brutalidade do pai alcoólatra e a insensibilidade do namorado, para um e para outro não passa de uma válvula de escape. Anteriormente à entrada de Denise no enredo, foi possível entrever o estrago que se operou na vida da muçulmana Amma e, comparadas as duas figuras femininas, pondo-se à parte a bela plasticidade atribuída à oriental e a feiura vulgarizada da jovem ocidental, resta um quadro geral deprimente no que se refere à valorização da condição feminina. No nível do entrecho,

\footnotetext{
"I don't get it."

"I am thinking of the future. But God could make it easier for us all if he simply made it possible for my people to march out in peace. Back home many of us continue to suffer."

She looks up at him.

"I wish they'd kill my dad." (DS,187)
} 
fica registrado o desperdício e a desorientação que envolve a vida dessas mulheres, desorientação que mais tarde poderá ser comparada com a trajetória de Dorothy, mais velha do que as primeiras, com maior recurso de auto-análise, mas com semelhante infelicidade. No nível do efeito literário final, vale observar que é o olhar do forasteiro africano, estrangeiro e ignorante, tanto a cerca dos modos ocidentais como dos orientais asiáticos (Paquistão e Índia, provável origem de Amma), que vai dar maior relevância à atuação feminina. É o africano recém-chegado que traz consigo a capacidade de espanto quanto ao que passa por "normalidade", como olhar as pessoas sem respeito, vitimizar as mulheres e descumprir qualquer responsabilidade ligada à masculinidade. $\mathrm{O}$ africano tantas vezes visto como primitivo é o elemento desestabilizador que impõe com sua perspectiva, o exame das relações deterioradas, o olhar renovador e atento que aponta a vida danificada e a necessidade de transformação.

Há ainda uma outra figura feminina de importância crucial para a sobrevivência de Gabriel na Inglaterra, a da advogada Katherine, especializada em pedidos de asilo por imigrantes, cuja atuação se articula, na fábula, através da área profissional e por efeito de contraste com a do advogado Stuart Lewis, que será o principal representante do africano junto à Crown Court - instância jurídica que lida com crimes mais graves, transgressões consideradas prejudiciais à sociedade como um todo, e não questões de disputas particulares. As atuações dos dois profissionais, sem que qualquer palavra explicativa do narrador determine, se apresentam em flagrante contraste, de forma que é possível deduzir o que move cada um desses agentes da lei. São três os episódios em que Katherine toma parte, dois dos quais como profissional da lei, diretamente referentes à posição de Gabriel como pretendente à obtenção de asilo e como réu, suspeito de abuso sexual da adolescente Denise, e o terceiro, individualmente, por decisão pessoal e voluntária, não mais ligada aos trâmites legais.

Todo o segmento, com apenas uma exceção de que se tratará mais adiante, constitui-se por meio de um narrador onisciente neutro que, embora venha até ali operando com ângulo de visão muito próximo do protagonista, torna-se agora quase imperceptível, atuando principalmente como um sóbrio diretor de cena que, esparsamente, surge apenas para articular a movimentação das personagens em conflito, retratar certos aspectos visuais que as caracterizam e, discretamente, registrar-lhes o gestual que colabora para que se vejam as diferentes mentalidades. Enfim, trata-se principalmente de cenas - diálogo e ação - em que 
surpreendentemente, cabe a Gabriel o papel de joguete nas mãos de um e de outro profissional da lei. Significativamente também, caracterizam-se os episódios pelo silêncio, ou melhor, pelas parcas respostas pronunciadas por esse protagonista que, na interação com os advogados, parece ter perdido o seu status de principal personagem e de lutador. Pior ainda, percebe-se como títere manipulado pelos advogados, que travam entre si uma disputa que ele não domina com clareza por ser oriundo de uma outra cultura, por estar numa posição inferior, aprisionado como suspeito, ainda mais por se tratar de uma acusação engendrada pela adolescente inglesa a mando do pai, acusação da qual ele é inocente e, principalmente, porque nada lhe é explicado.

É importante reiterar-se que a composição do entrecho no segmento, a forma como se entretecem partes de unidades narrativas referentes a diferentes conflitos e espaços da experiência do protagonista, acarreta uma carga cumulativa de impacto conforme as partes entrelaçadas progridem. A vivência na prisão e a viagem de emigração à Inglaterra podem ser consideradas as unidades dominantes do segmento, que se apresentam entrançadas por serem os cursos fundamentais pelos quais se desdobra a ação. Uma terceira unidade - relatos da vida na África durante a paz e durante a guerra - é salpicada por entre as outras duas conforme emerge à mente do protagonista, seja através da rememoração, seja através de sonhos ou pesadelos.

O pequeno trecho narrativo que antecede a primeira entrevista de Gabriel com Stuart Lewis, serve para sublinhar o ambiente opressor da prisão. Inicia-se com a menção do que ocorre na cela vizinha à de Gabriel, através dos sons que o protagonista interpreta: o prisioneiro vizinho berra, abafa-se o som dos seus gritos, e é carregado por dois policiais que o arrastam pelo corredor a fora. Anteriormente, Gabriel fora alvo de insultos racistas e impropérios arrasadores vindos desse prisioneiro inglês:

\footnotetext{
“Não sei por que eles se dão ao trabalho de te alimentar, seu animal do caralho.”(DS,96)(...)

"Vai beber a sua própria urina. Não é desse jeito que vocês fazem na selva?"98(DS,96)
}

Com linguagem mais disfarçada do que a utilizada pelo vizinho de cela de Gabriel e com o sadismo ligado ao prazer de chafurdar na sordidez da prisão, o carcereiro do período diurno destila o seu escárnio quando escolta Gabriel pelo corredor e quando este 
avista a cela vazia ao lado: -- "Quer que ele volte, é?-- O carcereiro acha graça. -- Aposto que você não tem muitas saudades
dele, não é mesmo?"’99

Adiante, quando Gabriel expressa preocupação por dar notícias à família do iraquiano Said, conforme prometera, é empurrado pelo carcereiro e claramente ameaçado: "É melhor ter cuidado e ver com quem você abre o bico". O carcereiro experimenta também, brevemente, o gosto de uma pequena forma de tortura: sabe que o prisioneiro está com fome e muita sede - efeito da injeção que o fizera ficar inconsciente na cela junto ao cadáver de Said, mas diz-lhe que não há tempo para comer o lanche e ver os advogados, impondo-lhe a escolha. Quando Gabriel engole o máximo que pode o mais rápido possível para poder ir ao encontro dos advogados, é observado com desprezo: "Olha para Gabriel como se estivesse estudando um animal no zoológico.”(DS,107). Certamente o leitor não se esqueceu das passagens em que os guardas armados olhavam para os emigrantes "sem respeito", e em que por dias esses emigrantes viajaram de trem com as janelas plásticas fechadas porque a polícia alfandegária, embora tivesse sido paga, "não desejava vê-los"(DS,103).

Por todo o romance, no que se refere ao protagonista, quer seja com a identidade de Gabriel ou a de Solomon, os índices relativos à forma como olham para ele, por quanto tempo sustentam o olhar, de que maneira o encaram e, também, de que jeito desviamno dele, ignoram-no e podem por algum meio suprimir sua presença, ligam-se aos modos pelos quais Gabriel/Solomon é levado ao silêncio. Mais uma vez, agora no decorrer dos encontros com os advogados, ressoa a pergunta de G. Spivak: "Can the subaltern speak?"'100

Stuart Lewis revela-se o protótipo do profissional liberal bem sucedido dos anos 2000: tudo nele é voltado para a obtenção de metas no menor espaço de tempo possível e as suas ações visam ao controle total dos dados necessários ao sucesso das empreitadas. É um representante das engrenagens da organização, do planejamento e da administração. Encarna o estereótipo da competência e da eficácia, qualidades que receberam nova significação na ideologia dominante no mundo desenvolvido atual. A sua caracterização ("uma máscara de concentração" 101 (DS,161) e gestual aproximam-no de um autômato programado para não se desviar da tarefa: proceder ao interrogatório e obter respostas que sejam adequadas ao 99 No original: "Want him back, do you?"-- He amuses himself with his own wit.-_Bet you don't half miss him, right?" (DS, 108). 100 Spivak, G., op.cit..

101 No original: “... a mask of concentration...”(DS,161) 
encaminhamento do caso.

Katherine, por oposição, dirige-se a Gabriel repetidas vezes, sempre consciente do fosso enorme existente entre o comportamento do advogado e o aparato da lei (já por si suficientemente intimidante para um cidadão comum, nascido no próprio país) e da compreensão que um africano recém-encarcerado poderia ter deles. Dirige-se sempre ao réu, chama-o pelo nome, na tentativa de pô-lo a par dos procedimentos e de deixá-lo mais propenso a compreender e colaborar através das respostas.

A cena realiza-se em torno da tensão que envolve os três participantes. Já o primeiro contato de Stuart Lewis com o africano se faz através de uma "tirada" que só na aparência tem algo a ver com o humor utilizado para quebrar o gelo. O que está por trás de sua aparente brincadeira é condescendência cheia de desprezo pelo suspeito:

\footnotetext{
-- Gabriel... Posso chamá-lo assim? -- Gabriel faz que sim com a cabeça, e o advogado sorri e logo continua a falar, rindo.

--Ora, obrigado. Não é bom logo assumir muita informalidade sem que se tenha permissão. -- Katherine sorri, constrangida. Gabriel escuta com atenção sem entender nenhuma palavra do que está sendo dito. ${ }^{102}$ (DS,110)
}

Um cidadão inglês de nível intelectual mediano, na mesma condição do suspeito, não deixaria de decodificar a alfinetada zombeteira do advogado de imediato, mas um homem como o africano, oriundo de outra cultura e submetido ao trauma da prisão, certamente não a perceberia prontamente. No entanto, por outras vias, que não a verbal, vai captar a falta de sintonia entre os representantes da lei.

A entrevista vai de mal a pior, com a demonstração da crescente animosidade entre os advogados, cujos métodos operacionais são opostos, e com progressivo silenciamento de Gabriel. Cria-se um ambiente carregado de exasperação em que nenhum dos participantes atinge seus objetivos. Stuart Lewis se atém à tarefa de obter dados específicos sobre o caso e por isso procede a um interrogatório mecânico do prisioneiro - em que dia o africano chegou à França, por quanto tempo esteve lá -, cujas respostas não correspondem às metas do inquiridor. Quando Gabriel diz: “ Desculpe-me. Nem sempre dava para ter certeza se era dia ou noite" ${ }^{103}(\mathrm{DS}, 112)$, o advogado não olha para ele, continua a escrever e reafirma a necessidade de se estabelecerem os fatos. O leitor acompanhou a infeliz trajetória de Gabriel e Amma e dos outros imigrantes até a França e sabe que é perfeitamente lógico que qualquer

102 No original: “' 'Gabriel, may I call you Gabriel?’ Gabriel nods, and the lawyer smiles and then laughs. 'Well, thank you. It doesn't pay to assume too much unauthorised informality.'”(DS,110)

103 No original: "I am sorry. It was not always possible to be sure if it was day or if it was night." (DS,112) 
ser humano submetido às condições da viagem no trem e da estada no grande campo de refugiados perdesse a noção do tempo cronológico. Em vão, a advogada Katherine intervém a favor do estrangeiro, insiste em explicar a impossibilidade mental de o prisioneiro contribuir com respostas objetivas e sugere repetidas vezes que eles, advogados, façam suas suposições aproximadas quanto aos dados concretos para irem em frente com a questão. O advogado finca o pé no seu método de trabalho:

-- Sabe, eu entendo que você esteja tentando ajudar, mas em casos criminais é necessário realizar uma verificação dos fatos muito maior do que nos litígios civis. Portanto, se ele não puder substanciar essas datas para mim, quer ele goste ou não, a sua defesa perderá força. - Stuart Lewis ignora tanto Katherine quanto Gabriel e começa a fazer anotações nos papéis. (DS,114) ${ }^{104}$

O interrogatório prossegue, mas a reação de Gabriel piora, ele "ouve a pergunta, mas sua mente a afasta tal como um boxeur que impede um golpe do adversário" 105 .

A comparação com uma luta é apropriada. O protagonista se posiciona nessa entrevista como alguém que é alvo de socos e pancadas. Suas reações físicas são caracterizadas: dirige o olhar para um e para outro advogado, ciente da incompreensão deles, observa a pilha de papéis sobre a mesa e custa a crer que tudo aquilo possa se referir a si próprio, a garganta queima, vai sendo tomado pelo próprio silêncio.

Katherine, embora muito envolvida no embate, por um momento demonstra perder a paciência:

--Espere, Stuart. -- Katherine se espanta com a facilidade com que esse homem quer
abandonar a entrevista. -- Temos que dar uma chance a Gabriel.-- Vira-se para o
prisioneiro. ---- Gabriel, você se lembra do nome dela ao menos? Com certeza, isso
pelo menos você é capaz de lembrar?
Gabriel olha para a mulher e lentamente, como se repentinamente percebesse que não
pode confiar em nenhum dos dois, nega com a cabeça. Não, não consegue lembrar. ${ }^{106}$
(DS,116)

Sim, é bem apropriado que se registrem as reações físicas, pois perante os advogados Gabriel perde parcialmente a identidade de sujeito, de ser humano completo, e é visto como suprimido de sua capacidade mental, torna-se próximo de uma presença corpórea, quase

104 No original: “'You know, I appreciate that you're trying to help, but in criminal cases we need to do a lot more than in civil litigation. So unless he can substantiate these dates for me, the case will, whether he likes it or not, be weaker.' Stuart Lewis ignores both Katherine and Gabriel and begins to write on his pad." (DS,114)

105 No original: "Gabriel hears the question but his mind blocks it, like a boxer might parry a blow." (DS,114)

106 No original: " 'Stuart,wait.' - Katherine seems alarmed by this man's willingness to abandon the interview so quickly. 'We must give Gabriel a chance.' She turns now to Gabriel. 'Gabriel, you remember her name at least. Surely you can remember that much?'

Gabriel looks at the woman and slowly, as though suddenly realising that he can trust neither of them, he begins to shake his head. No, he cannot remember." (DS,115) 
totalmente destituída de vontade própria. O silêncio pode ser visto como reação a essa tentativa de domínio por parte dos interrogadores; a linguagem e o pensamento de Gabriel são como os últimos redutos em que ele parece, por vezes, inconscientemente, não se submeter à transformação em objeto, a ser completamente reificado, privado da individualidade.

Em "Morals and Criminality", texto de Adorno a respeito dos escritos de Karl Kraus sobre a ética privada e sobre a legalidade, há uma passagem que pode nos levar a pensar mais profundamente sobre o que subjaz à atuação da lei e como isso se encarna na figura de Stuart Lewis, que se quer ver como portador de racionalidade e eficiência:

\begin{abstract}
"A razão instrumental, que passou a ser considerada como auto-evidente, se transforma em estupidez através de sua própria lógica, pensamento formal que deve sua própria universalidade e daí sua aplicabilidade a objetivos quaisquer que eles sejam à abdicação da especificidade que se obtém pelo conteúdo, por meio dos seus objetos. A inteligência tola tem a seu dispor a universalidade de seu aparato lógico - especialidade pronta a ser posta em prática. Foi o avanço desse tipo de inteligência que tornou possível o triunfo da ciência positivista; bem como, presume-se, o triunfo do sistema da lei racional. Homens de intelecto agudo não só asseguram sua própria auto-preservação por terem razão de modo agressivo; acima e além disso, eles também desempenham o que Marx chamou, com extrema ironia, de "trabalho socialmente útil". Porém, porque excluem os aspectos qualitativos das coisas por uma lógica que tudo subsume, os seus órgãos da experiência se atrofiam. Quanto mais os seus mecanismos de pensamento, inalterados por interrupções, se estabelecem por cima do que deve ser pensado, mais se distanciam do assunto em questão, substituindo-o, ingenuamente, por um método distanciado e fetichizado. Aqueles que se orientam, até em suas respostas, por esse método, gradualmente passam a agir em conformidade a ele. Eles obtêm a percepção tal como o sabichão para o qual o modo de se descobrir algo e organizá-lo em termos de categorias pré-estabelecidas suprime todo e qualquer interesse no próprio assunto, mesmo quando o acesso a ele se dá por meio da subjetividade. Em última análise, seus julgamentos e seus expedientes se tornam tão irrelevantes quanto os fatos acumulados compatíveis com a metodologia. Esta é neutralizada por sua falta de relação com o assunto em questão. Ela não recebe nenhuma iluminação; não há mais nada em que a inteligência auto-complacente possa inferir que o que é deveria ser de outra forma. $\mathrm{O}$ defeito do intelecto imediatamente se transforma em um defeito moral; a baixeza predominante à qual se acomodam o pensamento e a linguagem destrói-lhes o conteúdo e eles inconscientemente contribuem para a teia da injustiça total. ${ }^{107}$
\end{abstract}

107 Adorno, Theodor W.. "Morals and Criminality". In: Notes to Literature III. v.ii.(traduzido do alemão Noten zur Literatur. Rolf Tiedman (ed). Frankfurt am Main: Suhrkamp Verlag, 1974, por Shierry Weber Nicholsen New York: Columbia University Press, 1992, p. 50,51.) Tradução acima feita por mim da versão em inglês: "[...] Instrumental reason, which has come to be considered self-evident, turns into stupidity through its own logic, formal thought that owes its own universality and thereby its applicability to goals of any kind whatsoever to its abdication of specificity attained through content, through its objects. Foolish cleverness 
O advogado Stuart Lewis representa uma espécie de racionalidade obtusa. Vê a si próprio como voltado para o cumprimento do dever - compor o processo da melhor forma -, mas parece "[ter] os órgãos de experiência atrofia[dos]", já que não demonstra interesse algum em perceber a verdade do que de fato trouxe o africano ao encarceramento. É um advogado que conhece bem os mecanismos do sistema legal, sabe operar os controles e macetes para atingir determinados fins, mas seu pensamento está sempre dissociado do réu que deveria representar. "O que é deveria ser de outra forma" é declaração que bem serviria de mote à passagem ficcionalizada.

Katherine, mulher bem capacitada profissionalmente, encarna uma figura bastante emancipada, que parece ter ultrapassado a representação da mulher como apenas mais uma das categorias pertencentes ao conjunto constituído pelas chamadas minorias, muitas vezes consideradas como o "Outro" da visão dominante na sociedade burguesa ocidental, ou seja, os negros, os homossexuais, as minorias étnicas, índios, aborígenes, etc. $\mathrm{Na}$ narrativa, é figura mediadora por excelência - faz a intermediação entre o africano alienígena ilegal em busca de obter direitos de residência no Reino Unido, que também carrega a acusação de abuso sexual de uma menor, e o aparelho das leis de imigração. Esse trabalho se torna mais complexo porque, como há uma questão processual, ela é quase obrigada a medir forças com o advogado criminal que, logo de início, declara ter a função burocrática de montar o processo da melhor maneira possível para que ainda um outro advogado finalmente o apresente no tribunal. A complexidade das instâncias da lei, já por si misteriosas para pessoas nascidas no país, formam uma barreira ainda maior para o

has at its disposal the universality of the logical apparatus - a specialty ready to be put into action. It was the advance of this kind of intelligence that made the triumph of positive science possible, and presumably the triumph of the system of rational law as well. Men of keen intellect not only assure their own selfpreservation by being aggressively right; above and beyond that, they also perform what Marx called, with utmost irony, socially useful labor. But because they exclude the qualitative aspectsof things through a logic of subsumption, their organs of experience atrophy. The more their thinking mechanism, undisturbed by interruptions, estabilishes itself across from what is to be thought, the more it distances itself from the matter at hand, naively replacing it with a detached, fetishisized method.Those who orient themselves, even in their own responses, by that method gradually act accordingly. They attain realisation as the clever calf for whom the how, the mode of finding something out and organizing it in terms of pre-estabilished categories, suppresses any and all interest in the matter itself, even when access to it occurs through subjectivity. Ultimately their judgements and their arrangements become as irrelevant as the accumulated facts that are compatible with methodology. The latter is neutralized by its lack of relationship to the matter at hand. Illumination no longer comes to it: there is no longer anything in which self-satisfied cleverness can infer that what is ought to be otherwise. The intellectual defect immediately becomes a moral defect; the prevaling baseness to which thought and language accomodate eats at their content, and they collaborate unwarely on the web of total injustice. ..." 
entendimento do réu, como já vimos, mas Katherine, por ser sensível à posição do estrangeiro oriundo de uma formação diversa, com freqüência dirige a ele explicações simplificadas dos procedimentos que devem ser cumpridos, interpelações que procuram inteirá-lo da situação, enunciados tranqüilizadores no intuito de lhe infundir confiança no andamento do caso.

$\mathrm{Na}$ triangulação presente nas passagens em que se encontram Stuart Lewis, Gabriel e Katherine, ela é o elemento que atua de modo a estabelecer algum nexo entre as conhecidas brechas existentes entre a letra e o espírito da lei.

A ficção nos leva a pensar sobre a situação real de pessoas que necessitam ou querem emigrar. Nos últimos dois anos, tem havido ampla divulgação nos meios de comunicação de que a contribuição da força de trabalho dos imigrantes nos países desenvolvidos da Europa Ocidental é economicamente muito relevante. Entretanto, se por um lado há esse discurso favorável à movimentação de trabalhadores pelos continentes, por outro, sabe-se que muitos países tomam medidas cada vez mais fortes para impedir a entrada de novos forasteiros, principalmente em épocas que antecedem eleições. No Reino Unido, já com o sucessor de Tony Blair, neste ano de 2008 foi expressa a determinação de abrirem-se as portas da nação para os trabalhadores especializados em serviços, com melhor escolaridade, e fecharem-nas para a mão de obra simples, não especializada. É conhecido esse movimento de drenagem das melhores mentes e de parte do contingente de mão-de-obra especializada, força retirada dos países menos ricos, principalmente dos emergentes, mas não só deles, para os já desenvolvidos. Não custa relembrarmos, também, o significativo número de pessoas que perdem a vida na tentativa de obter entrada nesses países. Esse é um dos cenários da realidade inspiradores da fabricação da ficção contida no romance e no segundo e quarto segmentos em particular.

No segundo segmento, observa-se a criminalização de dois recém-chegados ao país, o iraquiano Said, acusado de roubo, quando na verdade foi vítima de um golpe aplicado por um casal de ingleses, e Gabriel, também acusado injustamente por outro inglês que pretendia obter indenização através da calúnia de atentado à filha Denise.

Quanto à criminalização do estrangeiro, estratégia que não é exclusividade inglesa, mas que tem sido usada desonestamente em diversos momentos da história em diferentes nações e mesmo em nossos dias ${ }^{108}$, é útil referirmo-nos aos estudos feitos por Paul

108 Lembre-se do discurso em prol da democratização dos muçulmanos em curso e das referências ao "Eixo do Mal", etc.. 
Gilroy em seu There ain't no Black in the Union Jack ${ }^{109}$-- título que traz a marca da variante linguística usada pelos negros jovens tanto na forma verbal coloquial "ain't” como no ritmo da frase e no modo popular como eles se referem à bandeira ("Union Jack")-- e em The Empire Strikes back: Race and Racism in 70 s Britain $^{110}$, que contém dados estatísticos que comprovam ser falsa a crença de que os jovens negros do Caribe sejam responsáveis pela maioria dos crimes nos centros urbanos do país. Gilroy registra em seus livros como a presença dos negros caribenhos foi sendo manipulada em discursos políticos na Grã-Bretanha, cujo efeito era o de apresentar a raça negra como um problema de difícil solução, sendo que as alas mais conservadoras da sociedade aderiram a essa retórica da necessidade de se manter a ordem e a lei ("Law and Order"-- frase utilizada nas campanhas da primeira ministra Margaret Thatcher), retórica essa fortemente sustentada sobre noções propagadas de "raça" (="branca") e nação, ou seja, xenofobia e nacionalismo. Paralelamente a essa onda conservadora de criminalização dos estrangeiros, nos anos 70 e 80 promulgavam-se várias leis que progressivamente restringiram a entrada de cidadãos oriundos de ex-colônias do Império Britânico, com o objetivo de se desfazerem os efeitos da antiga campanha promovida principalmente nas ilhas do Caribe, pelo governo britânico no período logo após a Segunda Guerra, para atrair trabalhadores de fora, pois o país necessitava do trabalho dos imigrantes em várias de suas instituições ${ }^{111}$.

Ainda um outro texto de Gilroy sugere que se continue a pensar cuidadosamente sobre a situação dos cidadãos originários das ex-colônias e dos emigrados de outros países: "It ain't where you're from, it's where you are at" "112 ["A questão não é de onde você veio, mas onde você está"]. O título criativo é resposta e reverte a perspectiva de um enunciado muito conhecido na Grã-Bretanha, utilizado por vários políticos, mas originariamente por Enoch Powell, conservador que se referia aos imigrantes e a seus descendentes como pessoas que se encontravam na Grã-Bretanha mas que não eram da GrãBretanha ("You're in Britain but not of Britain"). Note-se que na sentença em inglês, "You're in Britain", o verbo se traduz como "estar" na primeira oração, o que se liga a situação temporária; e na segunda oração, que subentende "You're not of Britain", o verbo se traduz

109 Gilroy, Paul. There ain't no Black in the Union Jack. The Cultural Politics of Race and Nation. Chicago: University of Chicago Press, 1991.

110 Idem. The Empire Strikes Back: Race and Racism in 70s Britain. London \& New York: Routledge in association with The Centre for Contemporary Cultural Studies of Birmimgham, 1982.

111 Sobre esses aspectos históricos, ver minha dissertação de mestrado, Trilhas pela água: história e ficção em Crossing the River de Caryl Phillips, FFLCH-USP, fevereiro de 2003.

112 Idem. “It ain't where you're from, it's where you're at". In: Small Acts. London: Serpent's Tail, 2000. 
como "ser", característica da existência e da origem, acima da temporalidade . Poder-se-ia trocar em miúdos: Estão de passagem, pois não têm raízes aqui.

Entretanto, na última década parece haver um movimento de maior sedimentação da idéia de que, de fato, a Grã-Bretanha é uma sociedade multicultural e os descendentes dos imigrantes das ex-colônias, alguns já na terceira geração, são cidadãos britânicos com direitos inalienáveis. Em 2005, a propósito dos conflitos ocorridos em Paris e em outros centros urbanos, em que imigrantes jovens da periferia protestavam contra a discriminação econômica e social, a Grã-Bretanha foi apontada como modelo muito superior ao francês na flexibilidade, de modo geral, de sua sociedade para a acolhida de imigrantes, fossem eles de origem caribenha, paquistanesa, indiana, africana, etc...

As posições favoráveis, as contrárias e as ambíguas, no que se refere à recepção de imigrantes e de refugiados, é um dos eixos do romance. A personagem Katherine representa, ao mesmo tempo, a crença individual de uma mulher inglesa de classe média alta nos direitos humanos de imigrantes ilegais encarcerados em seu país, e a agência de profissional da lei que ela corporifica conforme atua dentro da prisão e junto ao judiciário, na busca de estender e fortificar a linha de contato entre os preceitos humanos presentes na Lei e o modo como as pessoas, na outra ponta, os recebem. Katherine procura minimizar as deturpações da lei, principalmente quando esta é vista somente como pura forma do dever (o que é retratado em Stuart Lewis) -, procura ver a lei em sua grandeza, não apenas como regulação moral das ações, mas buscando efetuar as melhores práticas possíveis para o acusado. Assim é que, ao se inteirar do fato de Gabriel ter passado a noite encarcerado com o cadáver de Said na mesma cela, ao final da entrevista, até ali tão mal sucedida, após a saída de Stuart Lewis, Katherine parece aperceber-se da indignidade da posição em que a Lei colocou Gabriel e, embora limitada pelas dificuldades do caso, reafirma para o prisioneiro a necessidade de não desistir e de tentar se lembrar do que se passou no caso da garota. $\mathrm{O}$ comportamento do guarda, ao ser questionado pela advogada, encarna um exemplo da anomalia da Lei em uma de suas faces concretas:

\footnotetext{
“ --Ele morreu na cela e ficou largado lá no chão, caído como um cachorro. -- A mulher se vira e olha para o carcereiro.

-- Isso é verdade? Você deixou esse homem na cela com um morto? -- Encara o carcereiro com raiva. -- Diga, é verdade?

-- A senhora vai ter que conversar com o chefe. Não tenho nada a ver com isso. De
} 
qualquer modo, o tempo acabou, doutora. Infelizmente, a senhora tem que ir agora." ${ }^{113}(\mathrm{DS}, 117)$

Enfim, em diversos momentos Katherine é a personagem que mais atua como mola propulsora para que Gabriel se desvencilhe da situação criminal em que se vê enredado e para que busque a região da Inglaterra onde melhor poderia se integrar, que vem a ser o norte, mais pobre e menos desenvolvido. Katherine procura antecipar e contornar os problemas maiores que Gabriel iria ter saindo da audiência na qual ele se inteira do fato de não haver mais processo algum porque a adolescente se recusara a dar testemunho, o que invalidava o caso e o deixava em liberdade. A advogada age sempre de forma carinhosa, inclusive com gestos espontâneos, como o de pôr-lhe a mão no ombro, gestos que não são típicos na comunicação entre ingleses, mas que são modos de reforçar a linguagem que, no seu entendimento, Gabriel poderia não compreender. Enfim, Katherine explica-lhe a situação, dá-lhe o endereço de sua casa em Londres para alguma emergência e empresta-lhe dinheiro. Antes disso, sugere que mude o nome, devido à publicidade e ao perigo que poderia correr ao sair da custódia da lei, ao que Gabriel responde "não ter feito nada de errado", frase que aparecerá ainda cinco vezes no relato de outro encontro entre ele, Katherine e Stuart, dez páginas adiante, mas que por meio do recurso de flashback, refere-se cronologicamente à primeira entrevista com a advogada, ao final da qual o prisioneiro continua a olhar para a mulher que está indo embora "imaginando que seria da parte dela que a esperança poderia finalmente chegar" ${ }^{114}(\mathrm{DS}, 190)$.

Os avanços e retrocessos da ação geral e em referência à comunicação entre advogados e prisioneiro estão espaçados ao longo do segmento, não só para criar um efeito cativante ou intrigante na narrativa, mas para de fato aproximar o leitor da perspectiva de Gabriel, garantir que se mantenham na memória do leitor as experiências traumáticas vividas pelo protagonista. Assim, grande parte do fio condutor da história fragmentada de Gabriel se estabelece na situação de encarceramento dentro do país que ele via como Terra Prometida, último refúgio e única salvação. O segmento se abre in medias res e é da prisão que se rememoram outros tempos e outros lugares, a vida de Gabriel até chegar a esse confinamento.

113 No original: " 'He died in the cell and they let him lie there on the floor like a dog.'

The woman looks up at the warder.

'Is this true? You left this man in a cell with a dead man?' Katherine glares at the warder. 'Well, is this true?'

'You'll have to speak to the boss. None of my business. Anyhow, your time is up, Miss. I'm afraid you'll have to go now." (DS,117)

114 No original: [...]" imagining that it would be from her direction that hope might eventually emerge.”(DS,190) 
A primeira entrevista com os advogados, apresentada ao leitor em um texto de cerca de doze páginas (DS,106-118) é, na verdade, cronologicamente das últimas, já que se registra como sendo a véspera da grande audiência perante um juiz. Esse texto está cercado pela narrativa das tristes peripécias da viagem de emigração, anteriormente a ele narrou-se a exaustão da primeira parte da viagem desde a saída do continente africano por meio de ônibus e avião de carga (DS,96-106) até um ponto de partida para a França por trem; posterior a ele, narra-se a parte mais triste da viagem, cujo destino é a Inglaterra e que inclui a permanência em campos de refugiados e a perda das únicas pessoas com quem o protagonista tinha intimidade ou forte ligação, o tio Joshua e a muçulmana Amma. Do segundo texto (DS,161,162), a respeito da preparação do prisioneiro horas antes de ser levado ao tribunal, o leitor só tomará conhecimento depois de percorridas outras trinta páginas (DS,118-148), que compreendem predominantemente o restante das agruras da viagem (DS,118-161), inclusive a breve passagem em que o africano se encontra entre a vida e a morte após a travessia do canal, a separação abrupta do amigo Bright, as ocasiões em que conhece Denise e os relatos aqui e ali de pesadelos e lembranças atrozes. O último texto (DS,164-166), é prolongamento da situação do segundo, mas traz fechamento às acusações e significa que Gabriel não mais voltará à prisão, portanto dá a volta completa ao fio condutor do segmento que ali se iniciara. Depois de se despedir de Katherine, Gabriel, livre, é levado a Londres de carona por dois policiais , à metrópole a que almejara chegar e onde esperar-se-ia que poderia gozar a liberdade:

\footnotetext{
“--É verdade que na Inglaterra se pode sentir a liberdade no ar? Que é um ar diferente?”(DS,79) $)^{115}$

"Para além dessa prisão, está a Inglaterra. Há três dias quando eles o trancaram nesta cela com Said, Gabriel começou a duvidar se um dia chegaria a ver a Inglaterra de novo"(DS, 77$)^{116}$
}

A Inglaterra é um pólo de enorme significação em A Distant Shore, mas a África é o outro pólo que confere à obra um sentido pleno, pois é a partir do ponto de vista que a África tem da Inglaterra, da Europa, da Terra Prometida, que o velho mundo adquire dinamismo, o que possibilita aos protagonistas avaliarem o passado e pensarem sobre as possibilidades que o mundo abre à sua atuação. Tomado em sua extensão, pode-se pensar em $A$ Distant Shore

115No original: "[...]'Is it true that in England you can smell freedom in the air? That it is a different air?"'(DS,79)

116 No original: "[...] Beyond this prison there is England. Three days ago when they first locked him in this cell with Said, Gabriel began to doubt that he would ever again see England.’’[...](DS,77) 
como tendo predominância da experiência social na Inglaterra de fim de século e início do terceiro milênio, e, se examinados os segmentos, vê-se que se retratam principalmente situações na Grã-Bretanha. Sabemos já que o primeiro segmento focalizara uma inglesa de meia-idade no interior da Inglaterra; o terceiro volta a focalizar essa protagonista e a vida urbana na capital do país com as imperfeições que a caracterizam; no quarto segmento, observa-se a ação do imigrante em liberdade e a tentativa de finalmente estabelecer uma nova vida, em paz, no interior; no quinto e último, o foco retorna para a inglesa, mas agora deslocada de seu lar no interior e também da metrópole, internada em uma clínica para tratamento psicológico.

A África está presente neste segundo segmento de maneira bastante concreta nas partes do enredo em que constitui o espaço das experiências de Gabriel antes de cair quase morto nas areias britânicas: a juventude como mensageiro de uma repartição do governo, a vida como soldado na guerra, as idas e vindas para o norte e para o sul do país, a família, a fuga. Todavia, há uma dimensão da África enraizada na personagem, na sua maneira de ver o mundo, nas suas rememorações, que se presentifica em todas as esferas em que atua o protagonista e em que estejam registrados os seus pensamentos. Assim, a presença da África transborda todos os limites do campo restrito da fábula e se pode fazer sentir em outros momentos do enredo, momentos, por exemplo, em que Gabriel/Solomon encara vários aspectos e práticas da vida ocidental. $\mathrm{O}$ que resulta disso é que o leitor passa, às vezes, a incluir na sua decodificação da leitura ao menos o vislumbre de uma outra forma, que não a ocidental, de ver as coisas. Em outras palavras, a visão de Gabriel/Solomon funciona como um centro pivotal, irradiador de um movimento para um novo modo de se avaliarem as situações e as atitudes. A caracterização do ponto de vista de Dorothy é muito bem feita durante todo o romance, mas é a partir de Gabriel/Solomon e com Gabriel/Solomon que as interpretações podem se aprofundar, pois ele traz consigo, além do olhar de fora, o olhar do estrangeiro, a crença em se refazer a vida de um modo melhor, a visão utópica, inexistente em Dorothy.

De qualquer modo vale a pena nos determos nos trechos do segmento em que se narram situações referentes à África, sendo o principal deles o que surge quando Gabriel sofre a experiência de extrema proximidade da morte -- quando inconsciente, na praia inglesa, passam por seu pensamento as cenas principais de sua história, "o cinema de sua mente", imagens da sua vida. Trata-se de trecho de uma dúzia de páginas (DS,173-149), que se 
destaca do resto do segmento por vir narrado em primeira pessoa com forte tom de testemunho, o que acentua a pungência da narrativa e pode também trazer à lembrança a realidade histórica, os relatos de verdadeiros africanos que passaram por experiências traumáticas de guerra, tais como alguns ocorridos em Ruanda, quando, após a guerra, as pessoas se reuniam em círculo ao ar livre em espécies de tribunais populares, nos quais traziam a público fatos ocorridos, ou ainda, com um caráter um tanto diferente, os encontros promovidos por Desmond Tutsu, que visavam ao "Perdão e Reconciliação". Na História, fora do segmento, o testemunho é a forma típica por meio da qual os sobreviventes de trauma social tornam públicos e propagam, o mais que podem, os relatos do que se passou, com o intuito de se expurgarem da carga pesada da experiência não dividida, não compartilhada com outros, e, de algum modo, abrirem caminho para alguma forma de justiça e para alguma elaboração psíquica dos fatos, para poderem seguir em frente com suas vidas.

Recentemente, o filósofo Wladmir Saflate ${ }^{117}$ comentou o pensamento de Adorno sobre o sofrimento: em desmedida, o sofrimento exerce um caráter repressivo da identidade, desnorteia a personalidade em sua base estrutural, de modo que o verdadeiro ato moral implicaria o seu afastamento. Porém, alerta o professor, não se deve interpretar "afastamento do sofrimento" como "imperativo do conforto", que parece ser uma visão disseminada no mundo desenvolvido de hoje. O que o imigrante oriundo da África vem buscar na Europa desenvolvida não é apenas salvar a própria pele e gozar dos benefícios de utensílios domésticos, carros, eletro-eletrônicos, progresso técnico, mas é o sonho de viver com saúde, ter liberdade e, como diz Solomon, "cuidar dos filhos ainda não nascidos", porque, na terra natal, grande parte das gerações futuras estão fadadas à morte precoce ou a jamais nascerem.

O que se demonstra nessas doze páginas, aliás já brevemente resumidas anteriormente, é o horror, o quadro deplorável associado a um modo de vida em muitas regiões da África, sempre presente na imprensa e meios de comunicação, com freqüência dando origem a perguntas indignadas a respeito da permanência da situação infeliz do continente e da incompetência de instituições como o G8 [grupo dos países ricos], as Nações Unidas e a comunidade internacional em lidar com o problema.

No segmento, empurrado para os quadros do Exército de Libertação pelo próprio pai, que acredita na luta para a melhoria da vida de todos, o jovem Gabriel inicia uma viagem para

117 Idéias discutidas pelo Professor Wladmir Saflate em seminário promovido pelo Departamento de Teoria Literária da Faculdade de Letras, em conjunto com a Faculdade de Ciências Sociais da FFLCH-USP, sobre a Dialética do Esclarecimento de Adorno e Horkheimer, em 28 e 29 de agosto de 2007. 
fora da capital e logo toma ciência da precariedade presente em todos os espaços, precariedade essa presente fora da ficção também em muitos outros lugares do planeta $^{118}$ :

\begin{abstract}
"Nunca antes havia saído da capital. Conforme atravessávamos as favelas que se penduravam às beiras de nossa principal cidade, sem poder crer no que via, eu olhava para os abrigos feitos de lata retorcida que brotavam de terrenos semelhantes a lixões imundos. Embora nunca tivesse visto esses lugares com meus próprios olhos, essas favelas de telhados de lata, com as ruas patrulhadas por pedintes, eram bem conhecidas como o lar dos mutilados e deficientes físicos, um lugar em que enormes ratazanas se reproduziam livremente e onde perambulavam dia e noite. Continuava a olhar tudo, sem acreditar. Era essa a nossa cidade? Logo entrávamos pelo interior e corríamos em direção ao sul pela estreita faixa de asfalto, porcamente estendida sobre terra solta. As beiradas carcomidas da faixa de asfalto já haviam sido mastigadas pelo solo vermelho e estava claro que num futuro próximo essa "estrada" desapareceria. Não se via nada à esquerda ou à direita a não ser a grossa cortina da vegetação baixa.

O caminhão sacolejava e ziguezagueava como um bêbado e, conforme progredíamos rumo ao sul, passávamos por centenas de pessoas expulsas de sua terra que caminhavam em nossa direção com colchões, panelas e outros vários pertences em trouxas que carregavam na cabeça. Logo nos acostumamos com as barricadas de pneus em chamas que às vezes impediam o caminho e, finalmente, exausto, um dos nossos guias se levantou $[\ldots] "(\mathrm{DS}, 140)^{119}$
\end{abstract}

É esse o início da perda de inocência do protagonista que, a partir daí, fixa o olhar incrédulo em tudo e todos à sua volta, evita tecer comentários e se refugia num silêncio cheio de espanto quanto à situação do povo e à forma como se dá a luta: "os soldados não sabem lutar, só sabem matar"120(DS,138). Já de início, a caminho do sul, fica claro que os soldados vivem à base do consumo alternado de maconha e anfetaminas e estão apegados a pequenos pertences que muito valorizam, desde sandálias de borracha, bichinhos de pelúcia, máscaras do Pato Donald, esmalte para unhas, batons, maquiagem em geral, perucas, até os óculos de sol Ray Ban e tênis Nike, estes dois últimos sempre com o dono, o Capitão Bloodshed. Tratase de uma vida num mundo paralelo à normalidade, em que uma forte moeda de troca é a maconha. Alternam-se a narração dos ataques a pequenos lugarejos sob o poder das tropas do

118 Assunto analisado por Mike Davies em seu Planeta Favela. São Paulo: Boitempo Editorial, 2006.

119 No original: "Never before had I left the capital. As we passed through the shanty towns which clung to the edges of our main city, I stared in disbelief at the corrugated tin shelters which sprouted out of what looked like foul rubbish dumps.Although I had not seen these places with my own eyes,such tin-roofed slums, where beggars patrolled the streets, were widely known to be home for the disabled and maimed, places where huge rats bred freely and roamed by day and by night. I continued to stare in disbelief. This was our city? We soon passed into the countryside and sped south along the narrow strip of asphalt that had been laid clumsily over loose earth. The frayed edges of the asphalt had already been chewed by the red soil, and it was clear that at some point in the near future this 'road' would disappear. I looked to either side, but there was nothing except a dark curtain of bush.

The truck rolled and swayed like a drunk, and as we pressed further south we began to pass hundreds of displaced persons walking towards us with mattresses, cooking pots and bundles of possessions on their heads. We soon grew accustomed to the barricades of burning tyres that occasionally blocked the road, and finally, one of our escorts climbed wearily to his feet.[...]" (DS,140)

120 No original: "[...]They do not know how to fight, only how to kill." (DS,138) 
governo que logo eram liberados, as descrições sucintas de pessoas anteriormente mutiladas por tortura, a ação do grupo de abrir caminho no país afastando essas tropas, os momentos semelhantes a rituais carnavalescos em que os homens se fantasiavam, meio travestidos, e ganhavam apelidos ou outros nomes. Mais velho do que os outros, muito reservado e respeitado, Gabriel é batizado Hawk (Gavião) e alçado ao comando de um grupo. O encontro com o superior, o Coronel Bloodshed, deixa Gabriel ainda mais quieto e isolado. O coronel, semelhante aos ditadores africanos que ficaram famosos, é ambíguo, contraditório e inescrupuloso, uma figura bastante incompreensível para as mentes racionais. Ao mesmo tempo em que procura incentivar Gabriel e relembrá-lo de que o "maior insulto é não ser enterrado na própria terra"(DS,144) ${ }^{121}$, é capaz de recomendar práticas de superstição, como quando insiste que Gabriel libere o uso de maconha misturada com pólvora para que os seus jovens recrutas não tenham medo de serem perseguidos pelas pessoas que matarem: “[...]eles não terão medo de que o sangue derramado volte para assombrá-los. Não mais enxergarão pessoas, apenas galinhas a serem abatidas. Você deve encorajá-los a ceifar essas galinhas. Já está na hora de os homens do nosso país fazerem a colheita e comerem as galinhas." ${ }^{122}(\mathrm{DS}, 145)$

Vaidoso e orgulhoso de seus atrativos, o coronel conta a Gabriel os planos que sempre nutriu de ter sucesso no Velho Continente e como, no passado, prestara serviços sexuais às mulheres de diplomatas e aos turistas, na esperança de ser levado para a Europa e lá ser glorificado como um rei negro: “[...]Nunca seria um daqueles tipos "lá estive" que voltam como espectros dos homens que haviam sido, com suas almas africanas esmagadas por aquela gente. Meu corpo e minha alma retornariam à África triunfantes. Um rei negro. Olhe para estes pés! Apontava para os tênis Nike. Estes pés não foram feitos para sofrer a ação da sujeira. Quando estiver na Europa vou caminhar por toda parte sobre tapetes macios e eles vão idolatrar minha beleza negra. Cairão a meus pés, exaltarão o meu poder e a minha beleza. Vou pisar nos violinos deles e urinar nos seus CDs de música clássica. Vou lhes dar a África negra". ${ }^{123}(\mathrm{DS}, 144,145)$

121 No original: "[...] To not be buried in one's own land. Now that is the ultimate insult." (DS, 144)

122 No original: "[...] they will have no fear that spilled blood coming back to haunt them. They will no longer see people, only chickens that have to be slaughtered. You must encourage them to harvest the chickens. It is time for the men of our country to reap the harvest and eat the chiken."(DS,145)

123 No original: “ '[...] I would never be one of the 'been-tos', who come back as a ghost of the men they once were, their African soul crushed by these people. My body and my soul would return to Africa in triumph. Brown toast. Look at these feet.' He pointed to his Nike training shoes. 'These feet were not made to suffer dirt. When I go to Europe I will walk everywhere on soft material nad they will worship my black beauty. They will fall at my feet and proclaim my power and how handsome I am. I will stamp on their violins and 
Não há comentário algum da parte de Gabriel quanto ao lado farsesco e lamentável presente quer nos rituais de entretenimento dos soldados jovens, quer nos delírios desse coronel que tem diversos grupos de combatentes sob seu comando. Ao voltar para junto de seus homens, Gabriel é obrigado a atravessar vilarejos nos quais havia pouco lutara contra as tropas do governo e que agora se encontravam liberados, mas sempre em condições desvalidas:

“[...] vi as mulheres em uma fila comprida, à espera de pegar água perto de um único poço e as crianças nuas correndo em círculos brincando de se baterem com varas arrancadas das árvores e tive vontade de chorar por ambas as tribos do meu país. Meu próprio pai havia me enviado para participar dessa carnificina e, juro, eu não conseguia compreender o que é que ele pretendera com isso. A intenção era boa, isso eu entendia, mas o que sabia ele da guerra?"124 (DS,145)

A tristeza e o desalento vão se acumular e Gabriel permanecerá calado e quando, afinal, encontra seus homens, eles estão ainda delirantes de tanto álcool, drogas e orgias em vilarejos recém-capturados:

\begin{abstract}
"Olhei para Patrick e virei para o outro lado porque esses homens já sofriam o bastante nessa guerra infernal sem ter que suportar a minha língua ferina. $\mathrm{Na}$ verdade, não havia palavras em minha boca com as quais atingi-los. Eram jovens que lutavam na guerra porque alguém dera às suas famílias um saco de arroz ou lhes prometera um carro. Já há mais de um ano comiam o que lhes era dado e tinham perdido amigos. Caminhei para a sombra de uma árvore, sentei-me lá e fechei os olhos. Quando os abri já era noite." ${ }^{\prime 25}$ (DS,146).
\end{abstract}

Há muito tempo estamos expostos a representações do sofrimento no continente africano. Na literatura inglesa, em Heart of Darkness, para citar um exemplo, já se retratara o "horror" da África, horror causado em parte pela empreitada do "desbravador" branco nos confins do Congo belga em busca de marfim, a "desordem" do continente negro remexido pelos europeus, tudo sob uma névoa que tudo e a todos envolve e que deu lugar a uma riqueza de interpretações na crítica literária, muitas delas conflitantes. Aqui, neste breve extrato do

piss on their classical music CDs. I will bring them black Africa."” (DS, 144,145)

124 No original: "[...] I looked at the long line of women waiting at the solitary well for water, and the naked children running around in circles and playing the game of hitting each other with switches pulled from trees, and I wanted to weep for both tribes of my country. My own father had sent me to be a part of this slaughter and for the life of me I could not understand what he hoped to achieve. He meant well, that much I understood, but what did my father know of war?" (DS, 145

125 No original: "[...]I looked at Patrick and then turned away, for these men were suffering enough in this hellish war without enduring the lash of my tongue. In fact, I had no words on my tongue with which to lash them. These were young men who were fighting because somebody had given their family a bag of rice or promised them a car. For over a year they had simply eaten what they were given, and they had all lost friends. I walked to the shade of a tree and sat and closed my eyes. When I opened them it was evening. $(\mathrm{DS}, 146)$ 
segmento referente à guerra civil em algum lugar da África, não há possibilidade de névoa alguma: o sol é calcinante, a linguagem é propositalmente clara e se faz presente a representação imantada ao mundo referencial, bastante divulgado pela imprensa e muito mal conhecido pela maioria de nós, que temos dificuldade em acompanhar as especificidades das várias nações africanas, as disputas internas para alguns líderes políticos e elites negociarem a seu favor as riquezas do solo, as lutas entre diferentes tribos e grupos religiosos, a interferência muitas vezes maléfica de grupos estrangeiros, tais como os chineses, autodenominados "parceiros" na exploração de petróleo, minérios, etc..

A narrativa de Caryl Phillips vem juntar forças ao jornalismo fotográfico, que não pára de nos trazer retratos do sofrimento nos campos de refugiados, nos vilarejos queimados e entre os meninos-soldados.

No cinema, o filme " Si le vent soulève les sables" ("Se o vento balança a areia") 126 retrata o drama de uma família de migrantes que vai aos poucos sendo dizimada pela miséria da geografia, pela exploração de tropas em luta que lhes roubam os animais, pela atuação de soldados adolescentes que atiram em quaisquer civis e os matam porque parecem não ver outro mínimo raio de ação que lhes dê identidade ou lhes dê algum sentido. "Some time in April" ${ }^{27}$ é outro filme a mostrar com clareza a situação explosiva entre hutus e tutsis em Ruanda: como a ordem da vida foi despedaçada muito rapidamente, como se incendiou o país, em parte por meio de campanhas radiofônicas que incutiam o ódio racial na população.

No artigo "Uma Semana pelas Veias Abertas da Libéria"128, a escritora Zadie Smith e um grupo de jornalistas que percorreram a Libéria após Charles Taylor e o período de desestruturação do país comunicaram pelos jornais o panorama apocalíptico encontrado nas ruas da capital, Monróvia: "as pessoas ocupam a casca de uma existência anterior”. A escritora e os jornalistas estiveram com assistentes sociais ligados à OXFAM [Oxford Committee for Famine Relief] e à UNICEF, encarregados de trabalhar num projeto para a favela West Point. Um desses profissionais, Phil Samways, afirma que metade da população de Monróvia vive em favelas. Os autores do artigo relembram que a Libéria é também conhecida como Firestone Republic. A companhia de borracha americana Firestone comprou um milhão de acres (cerca de 400.000 hectares) do país em 1926, num arrendamento de 99

126 Produção belgo-francesa, baseada no romance Chamelle de Marc Duran Vallois, dirigido por Marion Hansel para Fortissimo films e premiado no festival de San Sebastian em 2006.

127 "Some time in April" ("Abril Sangrento"), escrito e dirigido por Raoul Peck, Cinefacto Productions, 2005.

128 Smith, Zadie. "Uma semana pelas veias abertas da Libéria”. O Estado de São Paulo. Caderno Aliás, J5. São Paulo: 10 de junho de 2007, pp. 4-5. 
anos ao preço irrisório de 6 cents por acre e, logo antes da época em que se deveriam realizar as eleições do final de 2005 (final do governo interino), a Firestone correu para obter mais 37 anos de concessão de exploração da terra, a 50 centavos de dólar por acre. Quanto ao governo, pode-se afirmar que o país passou todo o século $\mathrm{XX}$ sob a rédea de políticos injustos e ditatoriais. A história registra uma série de péssimos líderes: houve o presidente William V. S. Tubman (1943-1971), seguido por William R. Tolbert (1971-1980), e este por Samuel Doe, que aplicou um golpe de Estado ao invés de se retirar da presidência em 1990, quando também estripou o antecessor em sua cama. Charles Taylor, no poder de 1997 a 2003, foi julgado no Tribunal Internacional da Corte de Haia em 2007 por crimes de guerra, de lesahumanidade, por ter financiado grupos rebeldes em Serra Leoa e pelas atrocidades que encabeçou nos dois países. Homicídio, estupro, escravidão sexual, pilhagem e alistamento forçado de crianças foram as principais acusações contra Taylor, que fora eleito presidente em 1997 por ter liderado a Guerra Civil. Elegeu-se com o slogan "Matei sua mãe, matei seu pai, você vai votar em mim" (“I killed your ma, I killed your pa, you will vote for me.”). Deixou o país destroçado. A atual presidente, Ellen-Johnson-Sirleaf, eleita em 2005, é depositária da grande esperança do povo liberiano, mas a tarefa de reconstruir o país exigirá muito tempo e muito esforço.

Ella Coleman, até há pouco tempo comissária do projeto humanitário na favela West Point, continua a trabalhar para a recuperação de jovens e crianças afetados pela guerra. Quando lhe perguntaram se havia muitos ex-combatentes entre os alunos, ela disse: "Há excombatentes por toda parte. As pessoas vivem perto de rapazes que mataram as próprias famílias. Nós, como povo, temos muita coisa para curar”. Reconhece-se a vontade de obter forma semelhante de cura no enredo de A Distant Shore, pelas palavras da personagem Gabriel/Solomon.

Parece válido reproduzir do mesmo artigo de Z. Smith o depoimento de um rapaz de quinze anos que participa do programa de reabilitação promovido pela organização católica Don Bosco Himes para ex-combatentes infantis:

\footnotetext{
"Meu nome é Richard S. Jack. Eu tinha 13 anos em 2003. Estava vivendo com minha mãe quando começou a Segunda Guerra Civil. Estava jogando num campo de futebol quando homens vieram e me agarraram. Foi feito à força - eu não tinha desejo de entrar nessa guerra. Eles levaram os dois times de garotos. Eles nos jogaram num caminhão. Achei que nunca mais veria meus pais de novo. Eles me levaram para Lofah Bridge. Fomos ensinados a fazer certas coisas.
} 
Fomos ensinados a usar Aks-47. Fiquei com eles por um ano e meio. Éramos muitos tipos diferentes de liberianos e serra-leonenses, muitos meninos. Nas primeiras semanas, fiquei muito assustado. Depois aquilo se tornou parte de mim. As pessoas ainda não sabem do motivo daquela guerra. Eu sei. Foi um terrível mal-entendido. Mas isso já não faz parte de mim. Não quero mais violência em mim. Sempre que paro e penso no passado, tenho esta atitude: eu vou me levantar. Por isso eu conto às pessoas sobre o meu passado. Elas precisam saber quem eu era. Agora quero ser mais sábio. Meu sonho é me tornar alguém bom nesta nação. Tenho a sensação de que a Libéria poderia ser uma grande nação. Mas também quero ver o mundo. Quero me tornar piloto. Querem que eu leve vocês de avião a algum lugar? Claro. Venham me procurar daqui a 10 anos. Prometo que voaremos para outros lugares." 129

Os jornalistas Scott Johnson e Jason McLure ${ }^{130}$ recentemente publicaram artigo sobre a grande complexidade da guerra da Somália e a crescente multiplicação da violência: por parte dos rebeldes muçulmanos (União das Cortes Islâmicas) -- inclusive os grupos menores como o al-Shabaad, nome que significa "juventude"--, por parte do contingente intervencionista de soldados etíopes lutando em apoio às forças do governo,que pretendem se retirar do conflito logo, segundo o primeiro-ministro etíope Meles Zenawi e também por parte dos Estados Unidos em incursões contra as milícias rebeldes, as quais, conforme alega Washington, vêm se tornando cada vez mais radicais dando abrigo a membros da Al-Qaeda. Os jornalistas afirmam que, na tentativa de evitar que a Somália se transformasse em um outro Afeganistão, o governo americano contribuiu para criar ali um outro conflito como no Iraque.

Lamentavelmente, parece certo afirmar, sem se esquecer a raiz colonial do problema, que vários países do continente africano podem sim ser identificados com o que chamam “estados fracassados" ("failed states"), em grau ainda piorado devido à interferência perniciosa de muitos dos estrangeiros que lá estão lutando e que vieram a agravar uma situação historicamente por si complicada.

Em referência às décadas posteriores à Segunda Guerra, Eric Hobsbawm chama atenção para a enorme mudança na maior parte do mundo, pressionada pelas forças do desenvolvimento da industrialização e expansão do setor terciário, que foi aos poucos reduzindo as atividades agrícolas, excetuando-se dele áreas na África subsaariana, no sul e sudeste da Ásia e na China, em cujos territórios ainda se mantinha a vida do campesinato, baseada nos vilarejos e agricultura. ${ }^{131}$. Hobsbawn também afirma:

129 Idem.Ibidem.

130 Johnson, Scott e McLure, Jason. "Dilemmas of the Horn”. Newsweek. 21-28 de abril de 2008, pp.20-22.

131 Hobsbawm, Eric. "The Social Revolution". In: Age of Extremes - The Short Twentieth Century. London: Abacus, 1994, pp. 287-292. 
“[...]Nas regiões férteis com população não muito densa, como a maior parte da África Negra, a grande maioria das pessoas teria se arranjado bastante bem se tivesse sido deixada em paz. A maioria dos habitantes do continente não tinha necessidade dos seus estados, que, em geral, eram fracos demais para causar algum mal e, se eles se tornassem beligerantes demais, sempre poderiam contornar a situação através do retorno à auto-suficiência das aldeias. Poucos continentes iniciaram a era da independência com melhores vantagens, que logo foram desperdiçadas. ${ }^{132}$

O que se vê na primeira década dos anos 2000 é o estado calamitoso em muitas regiões da África. Órgãos de ajuda internacional têm sido atacados e impedidos de entregarem víveres para a população em estado de emergência em partes da Somália e um relatório da ONU declarou que o país é o pior caso de desastre humanitário do continente ${ }^{133}$. Acompanhamos também a péssima situação em Darfour, no Chad, no Quênia, no Congo e em Zimbabue. Obviamente, não se deve agrupá-los como se todas as histórias pregressas e causas fossem iguais. Sabe-se que leva bastante tempo, no que concerne a história do continente, para um leigo rastrear grosseiramente as várias influências políticas, as negociações e arranjos especiais orquestrados por diversos líderes contra o próprio povo. Não é sem razão que um historiador como Eric Hobsbawm se refere a essa parte do mundo como "o infeliz continente africano" 134 .

Através da ficção, A Distant Shore de Caryl Phillips apresenta aos leitores um enredo em que se confrontam vidas imaginadas na Europa e na África, vidas que brevemente se tocam na Inglaterra da atualidade. Neste momento da história, estão presentes as várias formas do preconceito contra imigrantes : há resquícios do preconceito dito "biológico", em que alguns se consideram superiores a outros; o preconceito cultural, em que os de fora são vistos como seres inassimiláveis pela cultura do país receptor; o preconceito social e econômico, acirrado pelo medo de que os estrangeiros tomem o lugar e os empregos dos nativos. Através da representação no romance dos poderosos entraves exercidos por esses sentimentos, o leitor é incitado a construir algumas pontes, a tentar dar um sentido em que

132 Idem. "The Third World". Op.cit.,p. 352. Acima traduzido por mim. No original: "[...] In fertile and not so densely populated regions, like much of black Africa, most people would have managed pretty well if left to themselves. Most of its inhabitants did not need their states, which were usually too weak to do much harm, and, if they grew too troublesome, could probably be by-passed by a retreat into village self-sufficiency. Few continents started the era of independence with greater advantages, which were soon to be thrown away. $[\ldots] "$

133 Johnson,S. e McLure. “The Dilemmas of the Horn”. artigo citado, 2008.

134 Hobsbawm, Eric. op. cit., p. 363. 
caibam as incongruências que permeiam a existência também fora do romance neste momento da história, problemas sobre os quais a literatura nem sempre nos leva a refletir.

O crítico Fredric Jameson chama atenção para a necessidade de se pensar sobre os acontecimentos do nosso tempo, em termos da globalização em curso, não exclusivamente do ponto-de-vista culturalista, que parece provocar uma série de graves erros. Alerta-nos para a necessidade de se pensar sobre a realidade, como faz Giovanni Arrighi, a quem cita:

\begin{abstract}
"Comunidades inteiras, países inteiros e até continentes, como no caso da África subsaariana, foram declarados 'descartáveis', supérfluos para a economia cambiante de acumulação capitalista em escala mundial. Somada ao colapso da União Soviética como potência mundial e império territorial, a ‘desconexão' dessas localidades e comunidades 'descartáveis' em relação ao sistema global de oferta desencadeou inúmeros e, na maioria, violentos conflitos a respeito de 'quem vem a ser mais descartável do que o outro', ou simplesmente, a respeito da apropriação de recursos que se tornaram absolutamente escassos como resultado dessa desconexão. De modo geral, essas lutas têm sido diagnosticadas e tratadas, não como expressão de auto-preservação por parte da sociedade contra o desmantelamento dos modos de vida estabelecidos sob o impacto da crescente competição no mercado mundial - que, na maioria das vezes é o que são esses conflitos; mas, antes, como expressão de ódios atávicos ou de lutas de poder entre os sádicos locais, quando, na melhor das hipóteses, ambos os casos desempenharam somente um papel secundário." $" 135$
\end{abstract}

Não é à toa que o protagonista do romance tem vontade de chorar por ambas as tribos em luta no seu país (DS,145), mas a sua visão mais clara e mais equilibrada quanto ao desperdício de vidas à sua volta não lhe garante proteção. Se, inicialmente, foi alçado a líder por inspirar respeito nos soldados em geral, depois, quando estes perdem a razão e aderem às práticas de pilhagem, estupro e dizimação das populações dos vilarejos que alegam ser favoráveis às forças do governo inimigas, Gabriel passa a ser malvisto, uma pedra nos

135 Arrighi, Giovanni. The Long Twentieth Century. Apud Jameson, Frederic. "Notes on Globalization as a Philosophical Issue". In : The Cultures of Globalization. Durham \& Londres: Duke University Press, 1998, p. 65. Tradução acima por mim, do texto em inglês: "Entire communities, countries, even continents, as in the case of sub-Saharan Africa, have been declared 'redundant', superfluous to the changing economy of capitalist accumulation on a world scale. Combined with the collapse of the world power and the territorial empire of the USSR, the 'unplugging' of these 'redundant' communities and locales from the world supply system has triggered innumerable, mostly violent feuds over 'who is more superfluous than whom', or, more simply, over the appropriation of resources that were made absolutely scarce by the unplugging. Generally speaking, these feuds have been diagnosed and treated not as expressions of the self-protection of society against the disruption of established ways of life under the impact of intensifying world market competition which for the most part is what they are. Rather, they have been diagnosed and treated as the expression of atavistic hatreds or of power struggles among local bullies, both of which have played at best only a secondary role." 
sapatos daqueles que estão à procura de qualquer forma de ação ou violência como válvula de escape para o horror em que todos vivem. Conseqüentemente, Gabriel deserta das forças rebeldes e foge para tentar proteger a família em seu vilarejo, mas os soldados do governo lá chegam quase ao mesmo tempo para praticar a vingança, como resposta à destruição do povoado pelas tropas rebeldes, ação que acreditavam ter sido liderada por Gabriel. O qui pro quo no enredo, a ação errada sob a 'crença' enganada que desencadeia outra ação errada em contrapartida, não é apenas um recurso literário, mas retrata o mecanismo pelo qual se desencadeiam muitos conflitos no continente africano: a retaliação vai se desdobrando em muitas ramificações e as guerras se prolongam muito mais do que deveriam, com pequenos intervalos em que se crê que o término tenha sido alcançado, mas as rixas são reorquestradas pouco tempo depois. Penso que é importante nos lembrarmos sempre, como argumenta G. Arrighi, que o que ocorre na África subsaariana não deve ser visto como ocorrência longínqua e isolada, independente da paz no mundo ocidental. As lutas devem ser analisadas também em suas raízes locais, mas é errado escusarmo-nos de pensar no problema da África sob a alegação de se tratar somente de disputas tribais impossíveis de serem examinadas, principalmente em suas ligações com interesses externos ao continente. ${ }^{136}$.

No segmento, em pouco mais de duas páginas(DS,83-85), através de uma composição que busca criar um efeito de forte verossimilhança pela concentração de detalhes descritivos, apresenta-se a cena em que os soldados do governo chacinam a família de Gabriel, que, escondido, assiste a tudo por uma fresta. Humilhado e torturado, também com palavras, o pai de Gabriel é morto e "Gabriel compreende que se trata de um esporte. Os rapazes estão fazendo um jogo com seu pai..." ${ }^{\prime 137}$. Os soldados, que atendem por apelidos semelhantes aos heróis debochados de filmes americanos do tipo western, reclamam e ralham uns com os outros, em desavença quanto à hierarquia e à prerrogativa de desfrutar o direito de executar o pai de Gabriel. A presença de Gabriel, trancado dentro de um armário, estabelece o ponto de vista pelo qual o leitor "assiste" à cena dantesca, mas, ao mesmo tempo, porque se trata principalmente de trecho narrativo com ponto de vista do tipo dramático ("showing"), em que se pretende apresentar a matéria narrada de maneira aparentemente neutra, com poucos termos qualificativos, resulta dessa articulação (entre o elemento interessado, que é Gabriel, e um narrador de status neutro), mais uma vez, a transferência do maior peso

136 Ver a esse respeito Serrano, Carlos e Waldman, Mauricio. Memória d'África. São Paulo: Cortez Editora, 2007. E também Reader, John. Africa: a Biography of the Continent. London : Penguin, 1998. 137 No original: "Gabriel understands that this is sport. The boys are playing with his father...”(DS,84) 
interpretativo para as mãos do leitor. Entre dois momentos de horror, a saber, a execução do pai e o estupro das irmãs baleadas, apenas se observa:

“A mãe e as irmãs de Gabriel se atiram sobre o corpo morto do marido e pai. Gabriel está acostumado com o som dos disparos. A brutalidade lhe é familiar. Assiste a tudo sem emoção, pois sabe o que está por vir. 'Smokin' Joe' ergue a voz e ao fazer isso parece crescer em estatura.’[...](DS,84) $)^{138}$.

O narrador não usa adjetivos para qualificar a cena, Gabriel também não emite juízos, mas está registrado que "a brutalidade lhe é familiar". Sabe-se que há tempos o protagonista convive com a desmedida, com os desvarios que caracterizam o comportamento dos combatentes nos conflitos e na guerra civil, que não param de irromper na África real, dos quais o leitor mediano estará ciente pela informação que lhe vem de todos os meios de comunicação disponíveis no século XXI. Entretanto, cabe aqui perguntar até que ponto e de que modos "a brutalidade será familiar" a esse leitor. Um ponto decisivo é que aqui se marca uma distância de envolvimento com o comportamento bárbaro dos soldados: o leitor, que provavelmente se comove com o sofrimento das vítimas, está colocado num plano bem afastado desse protagonista, que continua escondido para salvar a pele e a tudo assiste "sem emoção", inclusive prevendo o horror maior do que está por vir. É errado fazer afirmações sobre a intenção do autor, cair na "falácia da intenção", mas, de modo geral, pode-se dizer que a manipulação dos pontos de vista nessa breve unidade presente no segundo segmento do romance exemplifica a capacidade narrativa de Caryl Phillips e o fato de conseguir tratar de um assunto facilmente deturpável em sensacionalismo ou pieguice de rápido consumo, como aparece em tantos outros objetos da indústria cultural. Um dos valores inegáveis de sua obra é o de aprofundar o efeito da História na individualidade de personagens criadas sempre de maneira a estabelecer um espaço interpretativo que põe em jogo as formas de ver o mundo dos diversos grupos de leitores. É certo que todo escritor contemporâneo digno desse nome pressupõe a participação mais ou menos ativa do leitor na composição de suas obras. No entanto, como nos romances de Caryl Phillips sempre se articulam a ação dos protagonistas e as forças sociais com que se defrontam, interpelam-se variados modos de se pensar sobre esses embates que se representam em relação a períodos específicos da História e, sem

138 No original: "Gabriel's mother and sisters throw themselves across the body of the dead man. Gabriel is used to the sound of gunfire. The brutality is familiar to him. He looks on without emotion for he knows what is to come. 'Smokin' Joe' raises his voice, and as he does so he appears to grow in stature." (DS,84) 
dúvida, abre-se a oportunidade de se questionarem as ideologias com que se confrontam as personagens $^{139}$.

No segundo segmento de $A$ Distant Shore o protagonista, ainda na África, tem que se haver com as fabricações usadas para justificar o massacre de parte da população do país e verifica que não há saída: se foge e se afasta dos massacres promovidos como entretenimento para uma facção em luta, acaba por ver a própria família humilhada e dizimada de forma que a Inglaterra, país da Europa civilizada, livre de guerras civis e matanças como divertimento, só pode ser vista como um oásis e única oportunidade de sobrevivência.

$\mathrm{Na}$ Inglaterra, Gabriel sobreviverá por um período pouco maior do que um ano, cujo início é marcado por uma experiência inédita para esse homem oriundo de uma vida tribal, acostumado aos horizontes largos da África: a experiência do confinamento junto da escória inglesa e seus insultos racistas, que é obrigado a ouvir, além de ter de passar por outros traumas, como a imobilidade forçada por injeções que o deixam inconsciente para passar a noite trancafiado com o cadáver de Said. Talvez a imaginação do autor quanto à criação do horror numa prisão não cause aos leitores brasileiros choque tão grande, acostumados que estamos a conviver com notícias de variadas formas de desrespeito aos direitos da pessoa. $\mathrm{O}$ sociólogo Fernando Salla foi capaz de formular sucintamente uma reflexão sobre os cenários e acontecimentos dantescos que caracterizam a realidade das nossas prisões, com palavras que servem também para se pensar sobre a situação em outros países:

\footnotetext{
“Está presente em parte da sociedade brasileira a percepção de que há uma população pobre, miserável, composta por vidas que não têm valor, cujos corpos rastejam pelos escombros das cidades, pelas vielas enlameadas das favelas. Não são vistos como sujeitos de direitos. São indivíduos que podem viver nas condições mais degradantes, serem privados dos recursos mais essenciais de existência sem provocar grandes incômodos à consciência nacional. A existência daqueles indivíduos é considerada tão pífia (pois afinal são prostitutas, são simples empregados, são índios, são moradores de bairros pobres) que podem ter seus domicílios violados, serem espancados, violentados, incendiados e mortos." $" 140$
}

139 Um exemplo claro se encontra em "The Pagan Coast", o primeiro segmento do romance Crossing the River, em que, na década de 1830, um ex-escravo norte-americano culto, educado para se tornar missionário cristão, é enviado para ajudar na construção da Libéria como pátria dos negros livres e inicialmente se mostra confiante na ideologia disseminada pela American Colonization Society e por seu ex-senhor, a quem considera como pai e cujo sobrenome carrega. Paulatinamente, a personagem vai se defrontar com essa ideologia como instrumento de dominação e mascaramento da realidade em que foi colocado, realidade que exige que se cortem os laços com o passado nos Estados Unidos.

140 Salla, Fernando. "Afinal, quanto falta para o fundo do poço?”. O Estado de São Paulo. Caderno Aliás, J5, 9 de dezembro de 2007. 
A condição dos encarcerados na Inglaterra e nos países desenvolvidos da Europa é diferente da dos nossos no Brasil, onde não parece haver propriamente o funcionamento de uma sociedade civil moderna, em que vigora plenamente o contrato social. Recentemente, o historiador Carlos Guilherme Mota sublinhou a gravidade dessa questão:

“[...] a maneira como se pensa o direito no país permanece dentro de uma tradição estamental, do senhoriato escravagista. Desde o império, nossa sociedade nunca deixou de ser colonial e senzaleira, ainda que tenhamos transitado da economia dos escravos para a economia assalariada."

\section{(...)}

"Nós somos todos prisioneiros. Chegamos a um momento-limite da história. Não é que 'daqui para a frente é a barbárie'. Já é a barbárie. O sistema carcerário é apenas o intestino de todo um organismo doente." ${ }^{\prime 141}$

Se os nossos prisioneiros em geral não são vistos como sujeitos de direito, os imigrantes ilegais negros ou muçulmanos se aproximam dessa condição nos países do Primeiro Mundo.

No segmento, quando Gabriel se vê fora da prisão e quando se supõe que poderia enfim começar a desfrutar do "ar que cheira à liberdade" da Inglaterra mistificada é arremessado num roldão de experiências infelizes, entra em contato com vários tipos de malandros e golpistas, tanto de origem inglesa quanto africana, é enganado: a quantia de dinheiro que Katherine havia lhe dado é subtraída por uns e outros. Enfim, tem de se confrontar com a face cruel da metrópole e é levado de volta à estaca inicial de ter de recorrer à solidariedade da advogada mais uma vez. Vai se caracterizando um acúmulo de imagens e acontecimentos que apontam para uma situação sem saída -- a inexistência de refúgio e a necessidade constante de perambular de um lugar a outro quase sem trégua.

O centro de Londres é o espaço em que Gabriel perambula sem saber aonde ir e onde não há abrigo de espécie alguma, de forma que, contrariamente a muitas culturas dos povos africanos, que desconhecem a prática do suicídio, o protagonista chega a entreter a idéia da própria morte como encontro da paz que tanto busca:

141 Mota, Carlos Guilherme. "Você também está atrás das grades". Entrevista concedida a Fred Melo Paiva. $O$ Estado de São Paulo. Caderno Aliás, J4, 9 de dezembro de 2007. 


\begin{abstract}
"Algumas horas mais tarde, com frio e fome, Gabriel se vê a perambular pelas ruas nebulosas de Londres, uma cidade banhada pelo brilho intenso, amarelado e fosco das luzes do movimento da tarde. O céu era um cobertor cinza, suspenso ao alto sobre a cabeça de Gabriel, enquanto ao seu redor o tráfego rugia de modo que, qualquer que fosse a direção em que caminhasse, era impossível escapar do barulho terrível. Descobriu a ampla majestade do rio, local onde havia menos transeuntes e, com admiração, percorreu com o olhar os edifícios portentosos alinhados paralelamente às duas margens. No entanto, Gabriel não podia sentir prazer na visão desses lugares extraordinários, pois ainda não havia um mínimo de ordem em sua vida. Estava perdido. Caminhou até a metade de uma das muitas pontes e fixou o olhar no negrume lá embaixo; por um instante, imaginou como seria deixar-se cair na água fria e girar espiral abaixo através do reflexo de sua própria imagem. Talvez encontrasse a paz no silêncio e na imobilidade que subjaz na artéria prateada de Londres. Quando uma repentina onda de vibração do trânsito na ponte o trouxe de volta à consciência, Gabriel decidiu deixar esse rio e uma vez mais dar-se o propósito de procurar Bright no emaranhado das ruas da cidade. Entretanto, na medida em que o dia atribulado cedia lugar à consternação da noite, Gabriel era vencido pelo peso da tarefa e logo se mostrou ansioso por abandonar a busca." (DS, 168,169) $)^{142}$
\end{abstract}

A atração da metrópole não destituída de beleza na descrição focalizada pela percepção do estrangeiro se mostra vazia e capaz de induzir à morte, de forma que esse africano, despreparado para os movimentos da cidade, tem de buscar forças em sua capacidade de sobreviver, já testada ao limite e de vários modos na sua África natal e procurar um canal de vida que o faça seguir adiante.

O que a metrópole lhe reserva, como já se sugeriu, é decepção e humilhação, que vêm incorporadas nas figuras secundárias de Jimmy, de Emmanuel e de um transeunte sem nome. O fato de serem três pessoas a cruzarem o caminho do protagonista talvez sirva para criar um crescendo na caracterização do seu desamparo e espanto, face a essas figuras vulturinas. O primeiro, um velho inglês depauperado, aborda Gabriel após este ter passado a noite deitado

142 No original: "Some hours later a cold and hungry Gabriel found himself wandering the overcast streets of London, a city bathed in the weak yellow glare of afternoon street lights. The sky was a grey blanket that hung limply over Gabriel's head, while all around him traffic roared so that no matter which direction he walked in, it was impossible to escape the terrible noise. He discovered the broad majesty of the river, where the crowds were less dense, and he stared in wonder at the great buildings that lined each bank. However, Gabriel could take no pleasure in these incredible sights for there was, as yet, no order to his life. He was lost. He wandered to the centre of one of the many bridges, and he stared down into the blackness and, for a moment, Gabriel wondered what it would be like to drop down into the cool water, having first spiralled through his own reflection. Perhaps he might find peace in the silence and stillness that lay beneath London's silvery vein. As a sudden washing of traffic across the bridge shook him to his senses, Gabriel decided to leave this river and once more give himself purpose by searching for Bright among the endless streets of the city. However, as a troubled day gave way to the consternation of the night, this task began to overwhelm Gabriel and he was soon eager to abandon his quest."(DS, 168,169) 
no banco de uma praça, rodeado de outros desabrigados. Foi uma noite em que Gabriel acabou por se deixar adormecer por extremo cansaço, não sem antes estranhar as "frutas bizarras" que pendiam das árvores, imagem selecionada para representar o lixo e a degradação da metrópole ocidental:

\begin{abstract}
“[...]Embora cansado, não se sentia seguro e por isso manteve os olhos abertos e ficou olhando a árvore acima, com seus grandes galhos estendidos sobre o banco como um grande dossel. E foi então que notou maior quantidade deles, pendurados nos galhos como frutas de borracha descartadas, mas o cansaço era demasiado e não conseguia se mexer. Passou em revista os acontecimentos do dia, um dia que havia começado numa prisão inglesa e que agora chegava ao fim com ele deitado num banco de uma praça de Londres, capital do país.”[...] (DS,169) ${ }^{143}$
\end{abstract}

A passagem acima serve como mais um exemplo de boa parte da matéria apresentada por toda a narrativa de $A$ Distant Shore, criação imaginada pelo autor, mas ficção que contém forte ligação com as formas da realidade física e social da atualidade, abriga um núcleo mimético que sustenta a composição, cujo reconhecimento agudo e crítico forma um dos pilares importantes para a decodificação efetuada pelo leitor. No contexto social do nosso mundo, em que são tantas as mediações entre o homem e o que ocorre ao seu redor, tantas as formas que contribuem para uma sensação de desrealização generalizada, uma literatura em tom baixo, não pretensiosa, com um eixo de ligação forte com a realidade tem o seu mérito.

Em recente entrevista, falando sobre migrações em massa e sobre a discriminação étnica e racial, o sociólogo Francisco de Oliveira resume bem a situação:

\footnotetext{
"Há um risco de recrudescimento repressivo dos estados nacionais e também a formação de um racismo sublatente em todas as partes do mundo. Ainda não estamos experimentando isso no Brasil porque, por enquanto, apenas exportamos gente que não satisfaz suas expectativas de realização no próprio país. Como não há uma corrida do ouro no Brasil, ainda não testemunhamos movimentos migratórios dessa natureza, mas nossas cidades não passam, hoje, de vastos acampamentos de miseráveis - e aí as formas repressivas surgem para valer. O Rio de Janeiro é um capítulo à parte, por ter uma geografia peculiar, mas em São Paulo, o problema não é menor. Nos últimos anos vimos governos rotulados de progressistas tomando medidas repressivas na cidade, o que é espantoso. Construíram muros antimendigos, cercaram parques e
}

143 No original: “[...]Although he was tired he did not feel safe, so he stared at the tree above his head, the large branches hanging over him like a big black canopy. And then he noticed more of them, hanging in the branches like discarded rubber fruit, but he was too tired to move. He rehearsed the events of the day in his mind, a day which had begun in na English prison, and was now ending with him lying on a park bench in the capital city of London.” [...] (DS,169) 
desenvolveram projetos ambiciosos de revitalização como esse da 'Cracolândia', tudo para separar e excluir. Essas formas de repressão estão aí, à espera. Elas vão se reproduzir silenciosamente, como parte de um movimento malthusiano. Está sobrando gente para o capitalismo." 144

Trata-se mesmo de um fenômeno mundial, que merece ser atacado de variadas formas. O romance de Caryl Phillips não deixa de cumprir o papel de fazer que o leitor reflita sobre as relações humanas que se apresentam no mundo fora da ficção. Nesse sentido, por captar "o seu movimento[do real, da vida] e transformar em forma e em organização interna esse material eminentemente histórico e exterior" ${ }^{\text {"145 }}$, conecta-se com a tradição do romance realista e social, sem apelos panfletários.

No segundo segmento, a narração em terceira pessoa do singular serviu um propósito necessário: o de poder, através do narrador onisciente, colocado fora da ação, criar um terreno para o leitor participar ativamente e perceber o hiato existente entre as falas das personagens, os acontecimentos no desenrolar da trama, no modo como são entendidos sem dificuldade pelas personagens cuja mentalidade é a de uma cultura urbana, e, entre esses mesmos elementos quando decodificados parcialmente e em graus diversos, por personagens oriundas de outra cultura, pouco ou nada cientes das muitas intermediações nas práticas ocidentais. $\mathrm{O}$ hábil manejo da focalização variada nos protagonistas e, através deles, num jogo de iluminação e sombreamento, aliado a uma abertura à percepção do leitor, que se detém ora sobre um, ora sobre outro e também sobre a zona de intersecção criada na totalidade do romance é o meio para atingir os efeitos sugeridos acima.

144 Oliveira, Francisco de. "1968-2008 : Acima de tudo, uma rebeldia política". Entrevista concedida a Antonio Gonçalves Filho. O Estado de São Paulo. Caderno Cultura, D13, 11 de maio de 2008.

145 Vasconcelos, Sandra Guardini. "Um problema crítico". In: A Formação do Romance Inglês. Ensaios Críticos São Paulo: Editora Hucitec e Fapesp, 2007, p. 54. 


\section{ESPERANÇA}

Reiteradas as características referentes ao uso do foco narrativo e à interpelaçao do leitor nos segmentos anteriormente analisados, bem como a importância da abordagem do preconceito sob muitas formas, observa-se nos dois seguintes um movimento complementar, que retoma as histórias das vidas de Dorothy e de Gabriel/Solomon tanto numa direção horizontal, referente a variados contextos sociais criados ficcionalmente, a forças e cerceamentos com que se debatem os protagonistas, quanto numa direção de aprofundamento, em relação à introspecção na vida psíquica de cada um deles.

Esses segmentos podem ser vistos como se formassem um conjunto principalmente porque a trajetória narrada em cada um se direciona a um final semelhante. As passagens finais do terceiro e do quarto segmentos portam momentos de esperança dos protagonistas em relação à vida futura: Dorothy acredita que recomeçará uma fase positiva na nova morada (DS,268)e Solomon bate-lhe à porta com a crença de que finalmente se tornará menos só(DS,300)..

O terceiro segmento do romance retoma muito do que foi deixado em suspenso no primeiro, preenche muitas lacunas e dá detalhes sobre a trajetória de Dorothy, desde a juventude até pouco antes de conhecer Solomon. Desenha-se um arco: numa extremidade situa-se Dorothy com cinqüenta e cinco anos de volta a Weston, sua cidade natal, realocada como professora de música numa escola pública (mais democratizada e com alunos mais problemáticos, modificada pela reforma na Educação dos anos noventa), já divorciada há alguns anos e bastante isolada; na outra, Dorothy se encontra recém-chegada à nova morada no condomínio "Stoneleigh", a pouca distância de Weston, esperançosa de que seja o início de uma mudança para melhor, de uma nova fase em sua vida. Na primeira metade desse segmento Dorothy rememora e avalia a sua vida afetiva, o casamento em que se deixou ficar presa por décadas, o divórcio, dois relacionamentos insatisfatórios, que se materializam por sua iniciativa como forma de não ficar totalmente isolada, mas que não se traduzem em reciprocidade, vínculo, interesse pelo outro ou leve camaradagem. Nessa primeira parte, entretecem-se na história de Dorothy breves relatos sobre personagens masculinas: Brian, com quem foi casada, Mahmood, comerciante da vizinhança, e Geoffrey Waverly, colega de profissão. Esboça-se também o seu relacionamento inócuo com outros professores na escola, 
com a direção, com os alunos e com a própria profissão até se configurar uma crise - é obrigada a se afastar do trabalho para que se decida o seu destino como professora --, que leva a protagonista para Londres, para junto da irmã, de quem estava afastada.

$\mathrm{Na}$ capital do país, o ritmo de desenvolvimento da narrativa se acentua e num curto espaço de tempo Dorothy é obrigada a tomar uma série de providências práticas quanto à situação da irmã. A sensação de estagnação na maioria dos aspectos da vida de Dorothy, estagnação que se depreende da sua rememoração e reflexão sobre o passado que ruiu, paralelamente aos acontecimentos que a impulsionam a lidar com mudanças difíceis, criam a impressão de um fortalecimento interno crescente, resultado de uma compreensão histórica da sua vida, de uma visão mais correta sobre os acontecimentos do passado, um balanço ou acerto de contas a respeito do que foi construído e do que deixou de ser feito. Paralelamente, observa-se no terceiro segmento que a narrativa consegue captar os ritmos do cotidiano em cidades do ocidente e oferece uma espécie de etnografia parcial e ligeira da vida de vários indivíduos de classe média às voltas com a realidade e com o que almejam.

De forma sutil, num comentário relativo ao costume de se caminhar pelas ruas com as próprias pernas, em contraste com o de se trafegar trancafiado em segurança atrás do volante de um carro, abre-se o segmento também com o registro de preocupações freqüentemente mencionadas por pessoas da classe média urbana: a perda da beleza física e poder de atração de uma mulher que envelhece; a insegurança de se estar à mercê de assaltantes e malfeitores, de, em questão de poucos quilômetros, "encontrar-se em uma localidade britânica equivalente a Beirute", nas palavras de Brian (DS,195). Ao mesmo tempo em que se narra o fracasso do relacionamento do casal que se manteve junto por quase trinta anos, traça-se o perfil e apresentam-se algumas opiniões de um homem oriundo de uma família de classe alta, financista de carreira em um banco que, atingidos os sessenta anos de idade, abandona a vida estável e parte para o litoral da Espanha com uma mulher bem mais nova para lá abrir e dirigir uma pousada para turistas ingleses. Pela perspectiva da ex-mulher:

“[...] Em silêncio, por anos demais, ela suportara as conversas de Brian em forma de monólogo a respeito das vantagens de se contratarem os serviços de um arquiteto para projetar pátios internos e bancadas para refeições e da superioridade dos vinhos brancos da África do Sul se comparados aos Chardonnay franceses, conversas em que nunca buscava a sua opinião. Em outros dias, ele escolhia um assunto a esmo e se punha a reclamar. Ela por acaso percebera que até recentemente sempre podiam consultar um determinado médico, mas agora em todos os lugares o que havia era um grupo clínico e não se podia mais saber nas mãos de que diabo se iria cair? Ela se dava conta de que, por causa dos malditos sindicatos, os empregados do banco agora só podiam ter 'interface' com o público atrás de vidro ‘à prova de agressividade'? Dorothy logo 
percebeu que Brian não tinha o mínimo interesse por suas opiniões, mas, por nunca retrucar ela permitiu que ele olhasse através dela e além, até que finalmente ele se convenceu de que ela não existia. Quando Brian a deixou, também ela estava convencida de que ele partia sem deixar nada atrás de si e isso era doloroso.[...]" $(\mathrm{DS}, 199)^{146}$

A consciência de que ela própria tem responsabilidade quanto à sensação de desmoronamento da vida de casada junta-se à mesma sensação em outros aspectos, pois a vida de professora também não mais significava um esteio:

“[...]A carreira no ensino não tinha mais interesse para ela e, embora ainda obtivesse prazer com a música, não havia mais alegria. A alegria era uma emoção alada que voava às alturas, o que sugeria transcendência, mas a sua vida com Brian tinha uma âncora firme no chão. Nenhuma alegria.[...]"(DS,203,204) $)^{147}$

A vida de Dorothy vai se sedimentando como repetição mecânica, cumprimento de pequenos deveres, desempenho de uma função não investida de muito sentido, um devir que é quase vazio, que não é tempo carregado de experiências: “[...]... certa manhã [...] sentiu que enfrentava a futilidade de anos passados em luto por um homem que de fato nunca amara" ${ }^{148}(\mathrm{DS}, 209)$. Essa vida que é sentida como insípida e desnorteada de objetivos e sonhos contrapõe-se às forças propulsoras da vida de um imigrante como Mahmood. Num dos encontros com ele, Dorothy fica a par de sua história de vida, que compreende uma série de obstáculos, a começar pelo casamento forçado aos doze anos de idade no seu vilarejo no Punjab, época em que ele se sentia como "um objeto de troca, tal qual uma mula", em que se sentia desconsiderado em seus sentimentos e "usado como instrumento de barganha entre duas famílias rivais", passando pela humilhação de não ser respeitado ou temido pela mulher de quatorze anos, conforme os costumes da aldeia exigiam, até o ponto de ser aconselhado por uma delegação de homens do povoado a "bater nela como se fosse um tapete seu”(DS,200), o

146 No original: “[...] She silently endured too many years of his conversation in the form of monologues about the virtues of architecturally designed patios and breakfast bars, and the superiority of South African whites over French Chardonnay, conversations in which her opinions were not sought. On other days he would simply seize a seemingly random topic and start to complain. Did she realize that you used to be able to see a specific doctor, but now everywhere's a group practice and you never know who the hell you will be getting? Was she aware of the fact that because of the bloody unions, his bank employees were now only allowed to 'interface' with the public from behind 'anger-proof' glass? She quickly learned that Brian had absolutely no interest in her opinions, but by not answering back she allowed him to look through and beyond her, until he finally convinced himself that she did not exist. When Brian walked away, she too was convinced that he was walking away from nothing, and it hurt.[ ...]"(DS,199)

147 No original: "[...]Her teaching career no longer interested her, and although she still derived pleasure from music, it no longer gave her joy. Joy was an emotion which soared on wings, which suggested transcendence, but her life with Brian was firmly anchored. No joy.[...]" (DS,203,204)

148 No original: "[...] one morning [...] she felt herself finally coming to terms with the futility of years spent mourning a man whom she had never truly loved .[...]"(DS,209) 
que não estava em sua natureza. Pouco depois, atraído pelas histórias de progresso de outros conterrâneos no exterior - fotografados em poses em que "seguravam um rádio ou apareciam ao lado de um televisor ou simplesmente empunhavam um maço de notas de cinco libras"(DS,201) ${ }^{149}$, Mahmood resolve partir para o norte da Inglaterra, onde por dez anos será explorado pelos irmãos anteriormente emigrados, proprietários de restaurantes. Durante essa época será desrespeitado pelos fregueses ingleses bêbados, que o chamam de uma série de apelidos depreciativos e ofensivos. Mahmood acaba por se mudar para uma cidade ainda menos desenvolvida, que vem a ser Weston, já com a segunda mulher, e com as suas economias os dois abrem uma revistaria, onde vez por outra também é discriminado pelos fregueses locais. Do que sonhou conseguir na Inglaterra, apenas o trabalho é que se materializou:

\begin{abstract}
"[...]Ele imaginara que não haveria dificuldade em achar algum tipo de emprego bem pago no país da sra. Thatcher e, depois que tivesse economizado o suficiente, ambicionava ir para a universidade, na melhor das hipóteses para estudar Direito ou Medicina. Mahmood sonhava em algum dia retornar à sua aldeia triunfante como o homem mais importante da região, e tinha a intenção de cuspir na cara da mulher que o humilhara publicamente.[...]"150 $(\mathrm{DS}, 202)$
\end{abstract}

O leitor será capaz de reconhecer na ficção criada pelo autor referências a práticas sociais existentes ainda no século XXI fora da ficção. Há um grande número de temas compartilhados pela ficção, pela realidade e pelo estudo de um e outro, como no caso das Ciências Sociais, que podem ser encontrados no romance em questão, inclusive no terceiro e quarto segmentos. Um tema dominante, já apontado, é o da migração, emigração e imigração, três processos que se desenvolvem, na maioria das vezes, com bastante pesar pelos sujeitos que neles atuam e que, na linguagem corrente, muitas vezes aparecem confundidos, misturados, simplificados.

Robin Cohen, estudioso dos diferentes movimentos de diásporas no mundo, assinala como aspectos mais marcantes da emigração de indianos e paquistaneses e outros grupos

149 No original : "[...] photographs in which they posed holding a radio, or standing beside a television set, or sometimes just clutching a fistful of five-pound notes.[...]" (DS,201)

150 No original: "He imagined that there would be no problem finding a well-paid job of some description in Mrs. Thatcher's country, and after he had saved some money his ambition was to go to university, hopefully to study law or medicine. Mahmood dreamed of one day returning to his village in triumph as the most important man in the region, and he intended to spit in the face of the woman who had publicly humiliated him.”(DS,202) 
étnicos como os Sikhs do Punjab a reconstituição da vida em família nos moldes tradicionais, a manutenção das crenças e práticas religiosas, bem como das características patriarcais, cabendo à mulher o papel de ser dócil, recatada e obediente, muito semelhante ao sistema original de papéis desempenhados pelos membros da família no país de origem ${ }^{151}$.

Atualmente restaurantes indianos e revistarias ou pequenas lojas comerciais de esquina de proprietários paquistaneses se tornaram elementos já consolidados das cidades inglesas, assim como se tornou comum para os ingleses a convivência com certas práticas como a yoga, o interesse por tecidos e roupas étnicas e por outros produtos, tais como a música 'raga', etc.. Muitos desses passaram a fazer parte da cultura britânica como elementos 'coloridos', 'exóticos' e 'alternativos'. A grande variedade de identidades étnicas dos imigrantes oriundos do continente asiático foi homogeneizada no país-receptor sob uma única identidade, a que popularmente chamaram 'brown', desconsideradas as diferenças existentes entre elas. As décadas de 1960, 1970 e 1980 foram marcadas por formas violentas de racismo e ocorria o que chamavam de "Paki-bashing" ou seja, grupos de jovens racistas, geralmente de extrema direita, saíam em bandos para atacar imigrantes asiáticos e seus descendentes e danificar suas propriedades. Vários episódios desse tipo, além das tensões raciais e de gênero, foram retratados na literatura e no cinema. ${ }^{152}$

Ficam claras, no romance, as dificuldades relativas enfrentadas por Mahmood na Inglaterra e caem por terra os seus sonhos de volta triunfante ao vilarejo no Punjab, embora esteja claro também o fato de ter constituído uma nova vida com algum grau de melhoria material, com uma nova família no país do ocidente. A pequena parte do entrecho que se refere a Mahmood e à sua família acumula-se, na narrativa, a outras histórias de personagens que empreenderam a viagem de imigração e as diferentes formas que caracterizaram as suas expectativas em choque com a realidade possível, tais como nos casos referentes ao iraquiano Said, ao africano Bright, à muçulmana Amma e seu bebê, ao Coronel Bloodshed e, vista em

151 Cohen, Robin. "Labour and Imperial Diasporas: Indians and British". In: Global Diasporas - An Introduction. Seattle: University of Washington Press, 1997, pp. 62-65.

152 No filme "Minha Bela Lavanderia" ("My beautiful Launderette"), de 1985, dirigido por Stephen Frears, focaliza-se essa problemática em maior profundidade. Sua temática faz lembrar, parcialmente, o filme de 1971 dirigido por Stanley Kubrick, "Laranja Mecânica", baseado no romance A Clockwork Orange, de Anthony Burgess, em que se trata da alienação de jovens ingleses brancos e sua manifestação em atos de extrema violência gratuita. Por um período logo após o lançamento nos cinemas ingleses, o diretor proibiu o filme de ser exibido devido ao fato de ter provocado ocorrências em que se imitavam as cenas violentas na vida real. A esse respeito, ver Storry, Michael \& Childs, Peter (eds.) British Cultural Identities. Londres \& Nova Yorque: Routledge, 1997, pp. 259 e seguintes. Também a imprensa relatou muitos ataques racistas, conflitos entre brancos e filhos de imigrantes. O jornal "Folha de São Paulo" publicou longo artigo de Leonardo Cruz sobre esse tipo de distúrbio em várias cidades do norte da Inglaterra. Ver Cruz, Leonardo. "Intolerância cresce no norte da Inglaterra". Folha de São Paulo", 15 de julho de 2001, caderno A, p.17. 
maior profundidade, a de Gabriel/Solomon.

De volta à personagem Dorothy, observa-se uma ironia que se constrói em torno de seus relacionamentos com Mahmood e com o novo professor e colega na escola, Geoffrey Waverly. Comparando sua própria história de vida com a do oriental, Dorothy desvaloriza a sua:

\begin{abstract}
"Dorothy fala pouco sobre sua própria vida, preocupada em garantir que o discurso dominante seja masculino. Afinal de contas, a história dele envolve paixão, traição , migração, sacrifício e, por fim, triunfo. Mahmood é um sucesso. A sua própria história contém uma única palavra: abandono. Por curioso que pareça, Dorothy percebe que nenhuma das histórias tem a ver com a palavra 'amor', mas guarda esse pensamento para si.[...]"153 (DS,203)
\end{abstract}

Em pouco tempo o relacionamento se deteriora e Dorothy sente a indiferença de Mahmood e o desprezo da mulher deste, Feroza. Para si própria, mentalmente, não poderá fazer que "o discurso masculino predomine", como fingia ser o caso nos encontros com o paquistanês. Haverá várias situações em que se contrastam, com ironia, o comportamento britânico flegmático, a dignidade da professora de meia-idade e a aproximação de um ponto de saturação no que sente em relação aos outros, ao meio e também, obliquamente, à sua própria posição. Um desses momentos de quase-saturação ocorre quando Dorothy é tomada pelo fluxo de seu pensamento e se aliena da tarefa que deveria desempenhar. Ao invés de ensinar, olha pela janela e, numa espécie de turbilhão, misturam-se, por um lado, dados do exterior, como os alunos em observação na expectativa da aula que não se materializa, as referências em situação ambígua (o leitor não pode distinguir se foram exteriorizadas para os alunos ou ficaram só na mente de Dorothy) ao que deveria ser o conteúdo da aula, à grande criatividade, ao destaque de um genial compositor perante outros, e, por outro, o lado do seu interior, dados como a condescendência de agir de certo modo e de fingir em vários pequenos atos, recalcando a raiva e a insatisfação:

\footnotetext{
"Na segunda parte da aula dupla para os pré-universitários, os alunos encaram-na enquanto ela tropeça nas próprias palavras. Há pausas longas. O olhar dela se perde
}

153 No original: "Dorothy says very little about her own life, being concerned to make sure that the dominant narrative is male. After all, his story involves passion, betrayal, migration, sacrifice and ultimately triumph. Mahmood is a success. Her story contains the single word, abandonment. Curiously enough, she realises that both stories seem unconcerned with the word 'love', but she keeps this thought to herself.[...]” (DS,203) 
através da janela. Então vira-se para os jovens e ri. Tem consciência de que está fazendo papel ridículo na frente desses adolescentes. Tenta convencê-los dos relativos méritos de Mozart em relação aos seus contemporâneos. Na verdade, em relação a todos os músicos do período. Sacrifício. Faz a palavra rolar em sua boca. Sacrifício. E arrogância. Pára nesse ponto. De repente, é surpreendida pela palavra. Sente vertigem e pensa se deveria parar de falar e tocar algumas notas no piano. Demonstrar algo para eles. Sacrifício não é o problema. A vida com Brian envolvera abrir mão de sua dignidade. Sacrifício. Conheceu sacrifício a vida toda. Fazer frango ao curry é sacrifício. Perguntar a ele se já havia estado num lar inglês é sacrifício. Ouvi-lo falar sobre os anos de infelicidade no ramo de restaurantes em Leicester. Ir comprar o jornal de domingo na revistaria e manter uma conversa despreocupada sobre o tempo, enquanto os outros entram e saem e lançam seus olhares de ódio. Isso sim, é sacrifício. Podem encará-la se isso os deixa feliz, mas ela sabe o que é sacrifício. Arrogância, porém, é novidade. Mozart. Mahmood. Olhos arrogantes. Ninguém diz uma palavra. Apenas a encaram. Mas ela não está dizendo nada. E então ouve o sinal e sabe que hoje não vai mais ter que falar sobre Mozart ou sobre sacrifícios. Observa os alunos que arrastam as carteiras e se levantam. Juntam os livros e os papéis e olham para ela ao saírem. Olham para ela e ela retribui o olhar e dá um sorriso largo. Continuam a olhar para ela." $" 154$ (DS,211,212)

Haverá ainda outras passagens, como a compra de um presente corriqueiro (DS,213) as entrevistas com o diretor da escola (DS, 256), a conversa com o médico da irmã doente (DS,247), em que por pinceladas breves se mostram o estranhamento e o espanto dos interlocutores quanto ao seu comportamento, e serão delineadas, aos poucos, a perda do controle emocional, a irritabilidade sempre crescente com o funcionamento do mundo, a retirada do foco de atenção sobre o exterior para se voltar quase unicamente para os

154 No original: "During the second period of sixth-form music the pupils stare at her as she stumbles over her words. There are long pauses. She gazes out of the window. Then she turns to face them and laughs. She is conscious of the fact that she is making a fool of herself in front of these children. She tries to convince them of the relative merits of Mozart over his contemporaries. In fact, over all artists of the period. Sacrifice. She rolls the word around on her tongue. Sacrifice. And arrogance. Here she stops. She is brought up quickly against this word. She feels faint and wonders whether she should stop talking and play a few notes on the piano. Demonstrate something for them. Sacrifice is not the problem. Her life with Brian involved surrendering her dignity. Sacrifice. She has known sacrifice all her life. Making chicken curry is sacrifice. Asking him if he has ever been in an English home is sacrifice. Listening to him talking about his years of misery in the restaurant trade in Leicester. Buying a Sunday paper and nattering idly about the weather while others come in and out and cast their baleful glances, now that is sacrifice. They can stare at her if it makes them happy, but she knows about sacrifice. But arrogance is something new. Mozart. Mahmood. Arrogant eyes. Nobody says anything. They simply stare at her. But she is not saying anything. And then she hears the bell and she knows that today she will not have to talk any more about Mozart or about sacrifice. She watches as the pupils scrape their chairs and stand. They gather up their books and papers, and they look at her as they walk out. They look at her and she looks back at them and grins. They continue to look at her." (DS,212) 
pensamentos, a vida interior e tudo o que muito lamenta.

Quer seja em relação à cidade de Weston, quer seja em relação a Londres, o panorama pintado dos vários ambientes e atitudes sociais é amplo e detalhado, tanto assim que o leitor facilmente pode reconhecer a insatisfação que permeia a existência nos variados espaços. A vida na escola, as fofocas, os colegas que deixam as xícaras que usam sujas, desconsiderando os demais, a mediocridade daqueles em cargos de direção; o centro de lazer da localidade e o pouco prazer que se obtém ali; as idas ao hospital com a irmã que sofre de câncer, a menção a associações de apoio aos familiares de pacientes; as entrevistas com os policiais devido ao assalto de que foi vítima a irmã; o comportamento barulhento ou agressivo dos jovens nas ruas e nos ônibus, tudo, enfim, parece se agregar e se assemelhar em caráter negativo. São, quase todas, experiências às quais Dorothy não parece atribuir sentido, passando de uma a outra como se cumprisse uma condenação. "[...]Não são tempos felizes para ninguém" (DS,241) observa a personagem para si própria, quando testemunha um desentendimento entre um jovem e o motorista de um ônibus.

Somente em Londres, apesar de conviver com a morte gradativa da irmã, Sheila, Dorothy "sente que está onde deveria estar" e que, por ter-se decidido a se aposentar precocemente (o que, na verdade, foi uma saída prática, meio imposta pela diretoria da escola como alternativa a um possível processo e punição mais severa), poderia encontrar um sentido para a vida:

\footnotetext{
“[...]Aposentadoria precoce. E nada para preencher a vida, a não ser Sheila. Mas é uma nova bênção. Um propósito e uma oportunidade de consertar a história. Sente-se afortunada. Como se finalmente a vida estivesse começando. E quase todos parecem estar satisfeitos com ela." ${ }^{155}$ (DS,259)
}

$\mathrm{Na}$ verdade os outros estão satisfeitos por se livrarem dela: não a querem na escola porque houve reclamação formal por parte do novo professor, que se sentiu ameaçado em sua privacidade e com quem Dorothy tivera um relacionamento superficial; também Feroza, mulher de Mahmood, muito se alegrou com sua partida; a única aluna particular de música, Carla, acabou por se afastar e desistir das aulas por não ter talento e pela interferência da mãe, que não aprovava a preferência da professora pelos laços de amizade com um africano ao invés de seus vizinhos brancos do condomínio. Dorothy tem que se dar conta da ausência de

155 No original: "[...] Early retirement. And nothing to fill her life with, apart from Sheila. But this is a new blessing. A purpose, and a chance to repair history. She feels fortunate. As though life is now finally beginning. And almost everybody seems happy with her.” (DS,259) 
ligação genuína com os outros, tem que se haver com o isolamento que a acompanha há muito e que vai se tornando uma questão premente. Os relacionamentos com Mahmood e Geoffrey Waverly não a fortaleceram, e, embora se aproxime da irmã doente e seja solidária nas suas últimas semanas de vida, não se recupera fundamentalmente o elo enfraquecido. Entretanto, o tempo passado em Londres traz a Dorothy a capacidade de agir prontamente na resolução dos problemas práticos de Sheila e a oportunidade de fazer tudo a seu alcance quanto a pequenos gestos, tais como não se descuidar das velas que agradam à irmã ou a providenciar chá ou mesmo água morna, tal a sua debilidade física.

Do mesmo modo que em outros segmentos, narra-se uma situação melancólica sem que aflorem comentários mais claros sobre isso. Tanto pela inclusão de detalhes quanto pela narração de ações mais contundentes de Dorothy, desacompanhados de comentários e com rara adjetivação, vai-se dando forma a uma linha de sustentação do segmento, adicionada ao já referido uso do foco narrativo, que chama atenção para o entrelaçamento das situações cotidianas com as de outra ordem, daquilo que é menor e daquilo que é premente, que, no caso é a preparação da morte de um ente próximo.

Personagem secundária, Sheila quase não tem atuação direta, mas é elemento articulador de tempo: do presente, da época de um passado não tão remoto-- desde o seu afastamento da família já como jovem adulta--, e do passado mais distante, relativo às raízes da família. É elemento que interliga modos de vida muito contrastantes: por um lado, as formas rígidas de funcionamento de uma família patriarcal da classe operária inglesa, com um pai particularmente centralizador e autoritário e uma mãe fraca, submissa e desatenta, base de sua origem e formação; por outro, uma forma de vida que, em alguns aspectos, se rebelava contra a "ordenação das relações humanas na sociedade, que as convenções sociais e as proibições expressavam, sancionavam e simbolizavam" ${ }^{156}$. Esta última é geralmente vista como mais interessante, mais presente nos grandes centros urbanos, e para Sheila incluía o convívio com profissionais ligados às artes (o ex-marido cineasta e seus colegas) ou a políticas alternativas (a ocupação em uma Organização Não-Governamental a serviço do Partido Trabalhista, com o objetivo de disseminar a "Revolução Trabalhista" do governo de Tony Blair, fato registrado de passagem, mas aberto à avaliação do leitor), e incluía também o relacionamento homossexual com a personagem Maria, geralmente apenas mencionada por

156 Hobsbawm, Eric. “Cultural Revolution”. In: The Age of Extremes. Londres: Abacus, 1994, p .334. Acima traduzido por mim. No original: "[...] they rejected the long-established and historical ordering of human relations in society, which the social conventions and prohibitions expressed, sanctioned and symbolized." 
terceiros e nunca representada diretamente. O leitor está a par, pelo primeiro segmento, da presença de Maria no funeral da mãe de Dorothy e Sheila vários anos antes e, por este terceiro, sabe que Maria, afastada de Sheila nos últimos tempos, ligara-se em segredo a Derek, chefe da ONG trabalhista. Resta a Dorothy o papel forçado de ser depositária da ligação secreta de Derek e Maria -- vista por ela como traição--, evitar que a irmã debilitada se inteire desse assunto e agilizar a sua demissão da ONG e outros expedientes da vida prática. O que se pode ressaltar dessa parte da narrativa é o forte contraste entre a solidez da vida de uma família da classe operária, num mundo aparentemente mais fácil de ser entendido, anterior aos anos de 1980, vida que não se representa como idealizada - lembre-se aqui a alusão à tentativa de abuso de que Sheila fora vítima - e a desintegração dos núcleos familiares, sua substituição por outras redes de ligação, e a constatação, pela protagonista, de que uma e outra formas de vida são insatisfatórias.

Um episódio em particular, referente à violência urbana sob a forma de um assalto de rua - tão conhecida e corriqueira em muitas cidades do ocidente -, oferece-se para que se comparem as diferentes reações das irmãs inglesas, dos policiais encarregados da ocorrência e do próprio assaltante, quando abordado. Sheila, vítima do assalto ao sair do hospital, prefere não dar queixa contra o jovem assaltante negro porque se preocupa com o que possa lhe acontecer na prisão, opinião que expressa para os policiais, os quais imediatamente desconfiam de que não se trata apenas do roubo de uma bolsa, mas que deve haver algum conhecimento prévio entre criminoso e vítima.

Indignada com o oportunismo cruel contra uma pessoa visivelmente tão fragilizada, Dorothy decide rastrear o endereço do assaltante e ir até ele para recuperar o que é possível dos pertences da irmã e interpelá-lo. Obviamente, ela nada consegue. Na visão de Dorothy, o homem lhe abre a porta porque pela sua aparência ele imagina se tratar de alguma assistente social ou oficial encarregada de liberdade condicional. Antes do curto diálogo, será descrita com poucos e fundamentais detalhes a cena de pobreza imutável dos arredores e, em especial, do tipo de moradia do assaltante:

“[...]Assim que ela desce do ônibus, o conjunto habitacional se estende à sua frente como uma grande sombra, uma vasta paisagem de apartamentos populares, cães latindo e grama amassada. A imundície está espalhada por toda parte e um bando de crianças está jogando o que parece ser um jogo de futebol organizado usando uma lata ao invés da bola. Ela passa pelo "Bojangles" e pode ver que é uma antiga igreja católica que se 
transformou na discoteca do conjunto e depois passa pela piscina ao ar livre, com a pintura descascada e cheia de rachaduras, com aparência de jamais ter visto água alguma." ${ }^{157}$ (DS,264)

Há também ironia nos nomes grandiosos da alameda e do bloco de apartamentos "Pretoria Drive" e "Pretoria Mansions"--, que incide ainda sobre o histórico da verdadeira Pretória na África do Sul, sobre as suas diversas idas e vindas em sua relação com a GrãBretanha, além de ser, tradicionalmente, a província mais rica do país, famoso pela discriminação racial, emprestando agora o seu nome a uma das áreas londrinas mais pobres como é a de Brixton.

Novamente, não haverá comentários qualificadores, favoráveis ou contrários ao agressor ou àquela que vem em nome da vítima, apenas a apresentação de fiapos de três diferentes pontos-de-vista: a desconfiança dos policiais, a preocupação de Sheila com a sobrevivência do agressor e a indignação de Dorothy. São três visões oriundas de pessoas que se encontram do lado da legalidade. O impacto maior surgirá, por estranho que pareça, de um momento inicial de humor, que se capta na espontaneidade do vernáculo impiedoso do assaltante, confrontado pela mulher de classe média, que subiu vários lances de escada até chegar à sua porta:

“--Vim por causa da minha irmã - diz ela.

-- O que tem a ver? Não sei quem é sua irmã.

--Você a atacou e a roubou. - Ele estica o braço para baixo e empurra a menina para dentro do apartamento. E então sai para o corredor desse terceiro andar, forçando Dorothy a dar uns passos para trás. Fecha a porta atrás de si e então, bem devagar, deliberadamente, mede-a de cima abaixo.

-- Trouxe o pára-quedas? - Ela nada diz. - Porque, foda-se, você vai mesmo precisar de um, se vem aqui assim, falando desse jeito.

-- Você pode ficar com o dinheiro. Eu só quero as coisas dela de volta, só isso. - Ele a mede de cima abaixo outra vez.

-- Sabe, você tem cara, mas pode se mandar. Se alguma vez eu puser os olhos em você de novo você vai se machucar feio, estou sendo claro? - Ela fixa o olhar nele e se pergunta que possível nobreza Sheila conseguia ver nesses selvagens. Ele estava sendo

157 No original: "[...]As she steps from the bus the estate unfolds before her like a dark shadow, a vast landscape of council flats, barking dogs and worn-out grass. Filth is strewn everywhere, and a group of kids are playing what seems to be an organised game of football using a can instead of a ball. She walks past Bojangles, which she can see is a former Catholic church that has now become the estate disco, and then she passes the cracked and peeling outdoor swimming-pool, which looks as though it has never seen any water." (DS,264) 
perfeitamente claro, ali parado transpirando sua imundície e regorgitando as palavras. $\mathrm{O}$ parentesco não está muito distante da selva." ${ }^{\prime 158}$ (DS,264,265)

A reação imediata à agressão irrompe no pensamento de Dorothy em forma de preconceito social e racial. "Esses selvagens" agem mesmo de forma muito diferente de alguém como ela, que não demonstra perturbação ou medo, é capaz de atravessar o bairro e, de forma clara e bem articulada, reclamar os pertences da irmã, tendo ainda a magnanimidade de conceder que o assaltante fique com os valores. O rápido diálogo entre a inglesa distinta e o assaltante negro está carregado de forças que ultrapassam em muito a esfera do embate de dois indivíduos que parecem se odiar.

Diferentemente do que ocorre entre outras unidades nos segmentos, o parágrafo seguinte se abre de modo a não traçar um corte brusco entre a ida ao conjunto em Brixton e a morte da irmã: " Uma semana depois de Dorothy ter ido a Pretoria Mansions, Sheila morreu. [...]"159(DS,265). Estabelece-se, mesmo de forma tênue, por contigüidade no mesmo período sintático, uma ligação entre os acontecimentos que, talvez, possa ser vista como um dos momentos em que a narrativa interpela o leitor, requisita sua reflexão sobre a complexidade das várias posições e contextos ali ficcionalizados e, no caso particular, apresentados face à situação extrema da morte.

Constituído pelo discurso de um narrador inserido na ficção, narrador-personagem, o quarto segmento é contraponto ao primeiro, que também se tratava de narrativa homodiegética. Ambos os segmentos se aproximam pelo paralelismo dos discursos em primeira pessoa do singular e se diferenciam por serem, cada um a seu modo, expressões de formações ideológicas contrastantes, referentes a Dorothy e a Solomon respectivamente.

Um dos ecos do segmento de abertura do romance, “A Inglaterra mudou”, se alarga e se aprofunda, apresentando-se modificado pela experiência de Solomon, que engloba a

158 No original: " 'I've come about my sister,' she says.

'What about your sister? I don't know who your sister is.'

'You attacked and robbed her.' He reaches down and encourages the girl to go back into the flat. Then he steps out onto the third-floor balcony, forcing her to move back. He pulls the door behind him, then slowly, and very deliberately, he looks her up and down.

'You got a parachute?' She says nothing. ' 'Cause you're gonna fucking need one if you come round here talking like that.'

'You can keep the money, I just want her things back, that's all.' He looks her up and down again.

'You know, you've got some front, but you can just fuck off. If I ever set eyes on you again you're gonna get hurt, am I making myself clear?' She stares at him and wonders what possible nobility Sheila might see in these savages. He was making himself perfectly clear, standing there sweating his filth and spewing his words. Two steps removed from the jungle.” (DS,264,265)

159 No original: “A week after Dorothy came back from Pretoria Mansions, Sheila died.[...]” (DS,265) 
identidade construída por Gabriel para a nova vida no norte do país. É um dos pontos mais evidentes de articulação entre as narrativas de cada segmento.

Exceto pelos raros diálogos com Dorothy no primeiro segmento e pelo breve trecho narrativo em primeira pessoa incrustado no segundo, em que Gabriel, quase morto, repassa mentalmente os momentos importantes de sua vida (DS,137-149), é neste quarto segmento que o leitor entra em contato direto com o protagonista, que agora se revela diferente da personagem Gabriel, cuja trajetória fora acompanhada desde a juventude na África. Agora solidifica-se um sentido do histórico da personagem, acompanha-se o processo por que passou Gabriel para se tornar Solomon e vê-se como a sua identidade modificada abarca o passado anterior à imigração, a via crucis até as praias inglesas e a vivência de um ano repleto de experiências não antes imaginadas, ano transcorrido em diferentes pontos e domicílios na Inglaterra.

Porque neste segmento não há o mecanismo de aproximação e distanciamento manejado pelo narrador em terceira pessoa do singular e porque o fluir da narrativa nos é transmitido pela personagem, parece haver maior transparência na comunicação: o leitor tem a ilusão de se tornar ciente das experiências e sentimentos de Solomon de maneira mais direta, através de um contato com o discurso sem intermediação. Além disso, a linguagem utilizada constitui-se de enunciados bem curtos, articulados em uma sintaxe descomplicada, de uma maioria de sentenças independentes ou períodos unidos por coordenação. Procura-se dar corpo à linguagem do imigrante africano que, embora traga consigo o conhecimento e a prática da língua do país que o recebe, devido ao fato de vir de uma ex-colônia, não faz uso da língua inglesa com a fluência que jorra solta, como no caso da personagem Dorothy. $\mathrm{O}$ imigrante preocupa-se com a perda da língua-pátria:

\footnotetext{
“[...]Minha única tristeza de verdade era a falta de algum conterrâneo com quem pudesse falar. Meu idioma ia secando em minha garganta e às vezes, quando não havia ninguém por perto, eu trazia à boca a minha língua materna e pronunciava algumas palavras para ter certeza de que ainda não a havia perdido.[...]"160(DS,284)
}

O isolamento e a falta de esperança em poder ter uma comunicação genuína também

160 Acima traduzido por mim. No original: "[...] My only real regret was the lack of anybody from my own country with whom I might talk. My language was drying up in my mouth, and sometimes, when nobody was around, I would place my language on my tongue and speak some words so that I could be sure that I was still in possession of it.[...]"(DS,284) 
se representam na passagem em que o amigo irlandês insiste em que Solomon o acompanhe ao bar da localidade e Solomon, traumatizado pelo golpe que lhe fora aplicado em um bar de Londres, recusa-se a ir, alegando primeiramente não beber e, depois, "o temor de ficar no meio de uma floresta de línguas"161.

Ligada à preocupação com a língua, há a preocupação com a fidelidade em relação à cultura de origem, o medo de, de alguma forma, trair a própria família, a tribo, as raízes ao se adaptar à vida na Inglaterra e ao criar novos laços afetivos com os Anderson e com Mike, grupo a que vê como família-substituta. Marca-se isso através dos pesadelos em que os pais verdadeiros aparecem-lhe com ar acusatório (DS,279) e vaticinam infortúnios, caso ele insista em permanecer junto desses estranhos. Anteriormente, ainda a caminho da casa dos Anderson, em um ponto de parada na viagem com Mike, depois de lavar o rosto e se olhar no espelho, Solomon pensa sobre as mudanças em sua identidade, ao mesmo tempo em que se espanta com o conforto e talvez, com o desperdício, do modo de vida no ocidente:

\footnotetext{
"No banheiro passei mal, mas logo que esvaziei o estômago, senti grande melhora. Na pia, descobri que o suprimento de água era tanto quente quanto frio e pareceu-me não haver fim para essa fonte d'água quente e fria. Lavei a cara e olhei-me no espelho. O rosto de um homem cansado fitou-me de volta. Não era o rosto de um homem de trinta anos. A Inglaterra havia me transformado, mas não tinha sido esse exatamente o motivo da minha vinda a esse país? Eu desejava a mudança.”[... ${ }^{162}$ (DS,275)
}

$\mathrm{Na}$ verdade, esse é o início de um nova fase em sua vida, em que de fato cria laços afetivos, desenvolve-se pelo aprendizado e por várias formas de trabalho que desempenha, fixa-se em um domicílio com um emprego, com documentos legalizados e ainda se propõe a oferecer à comunidade os seus préstimos de motorista voluntário para o hospital da cidade próxima. A transformação de Gabriel em Solomon começa a tomar forma pela sua inserção na casa dos Anderson e através da amizade com o motorista de caminhão que lhe dera carona para sair de Londres. Esse grupo de britânicos de nacionalidades diferentes - os Anderson são escoceses e Mike é irlandês - formam um esteio de solidariedade que permite a Solomon não sucumbir sob o peso dos traumas de sua própria experiência, tanto na África como mais

161 No original: "[...] I was fearful of being among a forest of tongues[...]” (DS,286)

162 No original: "In the toilet I was sick, but once I had emptied my stomach I felt much improved. At the sink I discovered that the water supply was both hot and cold, and it appeared to me that there was no end to this supply of both hot and cold water. I washed out my mouth and then I looked at myself in the mirror. A tired man's face stared back at me. This was not the face of a thirty-year-old man. England had changed me, but was this not the very reason that I had come to England? I desired change. [...]"(DS,275) 
recentemente na Inglaterra, mas, ao contrário, permite que ele tenha um pouco da paz com que sonhara e, a partir daí, vislumbre a esperança de vida com liberdade no futuro.

Por ser o relato de um estrangeiro que demonstra surpresa e espanto em relação a várias práticas culturais comuns no ocidente, relato de um homem que aos poucos se adapta a novas condições e que procura criar espaço para sobreviver ao ostracismo a que acaba relegado, que não perde a esperança de criar uma nova vida para si, solicita-se do leitor um olhar mais desarmado de sua visão de ocidental e mais capaz talvez de observar outros costumes, as muitas situações de isolamento e de relações humanas truncadas, estes dois últimos opostos ao que se apregoa de um mundo globalizado.

Tantos anos após a publicação das idéias de Frantz Fanon ${ }^{163}$, o estrangeiro negro ainda se sente reificado aos olhos dos outros "que o fitam com grande fascínio" (DS,274). Adiante, será admirado sexualmente pela adolescente Carla, cujo "peso do olhar" (DS,283) faz que ele se recorde de Denise. O protagonista reconhece também a sua própria dificuldade em distinguir as diferenças entre os britânicos que encontra: “[...] Em minha terra era relativamente simples distinguir um homem de uma tribo ou região diferente, mas entre estas pessoas eu me perdia.[...]"164(DS,274)

No entanto, mesmo que dependente do âmbito restrito dos Anderson, Solomon vai se desenvolver em muitos níveis: aprende logo a lidar com o dinheiro, com o transporte público, com o trabalho doméstico, e, até certo ponto, também com os meios de comunicação televisão e jornais impressos - e acima de tudo, aprende os diversos ofícios referentes à construção de moradias, a ponto de entreter o sonho de fazer uma casa sozinho:

\footnotetext{
“[...] Eu tinha adquirido experiência com encanamentos e embora minhas mãos tivessem sofrido muito no início, minha sensação era de que algum dia eu poderia ter conhecimento suficiente para construir uma casa sozinho" $[\ldots]^{\prime \prime 165}(\mathrm{DS}, 285)$
}

O discurso do imigrante traz ao leitor uma dupla configuração: para o entendimento raso, tudo pode ser visto como expressão do pensamento de um estrangeiro "primitivo", tornado ainda

163 Fanon, Frantz [1952]. Black Skin, White Masks. Trad. do original francês para o inglês por Charles Lam Markmann. Londres: Pluto Press, 1986.

164 No original: "[...] At home it was relatively simple to distinguish a man of a different tribe or region, but among these people I was lost.[...]" (DS,274)

165 No original: "[...]I had gained experience with plumbing and electricity, and although my hands suffered very much during this initial engagement, I felt as though I might one day have enough knowledge that I might build a house by myself.[...]"(DS,285) 
mais simples porque não passa de elemento supérfluo, facilmente substituível na vida da cidade interiorana e atrasada do norte da Inglaterra. Por outro lado, a simplicidade com que esse narrador descreve e tece comentários sucintos -- sobre, por exemplo, o pouco proveito que se pode obter dos jornais ou da televisão, sobre os objetos e móveis de plástico, sobre a comida que comem, sobre a maneira como os jovens passam o tempo à toa, sobre o pouco que se pode intuir da vida dessas pessoas, sobre as formas de solidariedade vindas dos velhos Anderson, que o ajudam a se inserir na vida do lugar, sobre o desprezo de que é alvo tanto por parte de outros trabalhadores da construção civil, inclusive imigrantes, como por parte dos jovens desocupados - faz com que o leitor se despoje parcialmente dos seus modos de ver esses elementos e assuma uma perspectiva menos petrificada sobre as situações e práticas que lhe possam ser familiares também fora do romance e sobre as possibilidades de mudança. 


\section{CONCLUSÃO}

As possibilidades de mudança no mundo real, fora da ficção, exigem uma conjunção de ações, de vontades e esforços por parte dos vários componentes da vida social (os indivíduos, o sistema econômico, o regime político, as leis e outras instituições) nos diversos países ou espaços. Essas possibilidades tornaram-se mais complexas a partir de meados dos anos 1980 devido às transformações entre o poder e os espaços geográficos no "mundo globalizado". Ocorre que esse mundo é na verdade uma constelação de territórios com variados graus de poder, já que "o capital é atraído para algumas áreas e não a todo o mundo como se veicula de modo ideológico" $166 \mathrm{em}$ favor da globalização. Há uma grande contradição no fato de que o mundo dito "globalizado" esteja repleto de leis e mecanismos jurídicos (discute-se no presente momento o aprisionamento de imigrantes ilegais proposto pela União Européia) que impeçam a livre circulação de pessoas e penalizem as que lograrem entrar nas cidades mais ricas do ocidente. Já há tempos se sabe que o que existe é a promoção da livre circulação de capitais, mas não de pessoas.

Nas últimas décadas os movimentos migratórios sejam eles motivados pela busca de trabalho ou de sobrevivência longe de conflitos armados ou de desastres ecológicos, têm-se agravado, de modo que se impõe a necessidade de melhor compreensão da questão e de melhor entendimento entre as pessoas.

Em entrevista de tom ligeiro concedida a Nahima Maciel, por ocasião da publicação da tradução de seu romance no Brasil, Caryl Phillips fala a respeito do multiculturalismo e da questão racial no Reino Unido e em outros países da Europa, mas não os identifica como o tema principal dessa sua obra; além deles, se diz mais preocupado com o isolamento e a falta de comunicação entre as pessoas:

"Com a internet e os vários meios de manter contato, é paradoxal que cresça o número de pessoas que vivem sozinhas, que têm dificuldade de manter uma conversa, pessoas com seus iPods e fones de ouvido, fechadas em si. Isso me interessa muito. Não estamos nos comunicando."

“Às vezes acho que estamos esquecendo de como é nos comunicarmos. E, para mim,

166 Ribeiro, Wagner da Costa. "Relações entre espaço e poder no mundo globalizado".O Estado de São Paulo, caderno Cultura, D 7, 18 de maio de 2008. 
essa é a coisa mais importante de ser escritor e de ser leitor."167

A palavra "comunicação", dentre muitas, foi utilizada de tantas maneiras que pode bem ser insuficiente para expressar a falta de entendimento e de empatia entre os seres humanos, a que o autor também se refere na mesma entrevista. A respeito da criação dos protagonistas afirma ter tido a intenção de criar "um africano de meia-idade e uma inglesa que normalmente nunca teria uma conversa com esse africano. Em outra entrevista ${ }^{168}$, Caryl Phillips aborda o legado da escravidão, do tráfico de africanos e a corrupção histórica sofrida por vários lugares do mundo e, por fim, afirma haver entre a África e a Europa uma conversa que falha, que fracassa.

Há uma característica da arte literária que o professor Dominique Maingueneau chama de "paradoxo de fênix", ou seja, a capacidade, até certo ponto, de se redimir a destruição existente no mundo da obra pelo discurso que a institui. Dá como exemplo um romance que mostra "um universo de mentira e de incomunicabilidade sem recurso, no qual não poderia haver lugar para a literatura", mas afirma a necessidade "de se gerir o excesso constituído pela própria existência dessa narração". Ressalta que jamais o mundo é desprovido suficientemente de sentido para excluir a obra que o diz desprovido de sentido" ${ }^{169}$. Parece correto afirmar que o romance de Caryl Phillips pode ser visto como a concretização da comunicação desejada pelos protagonistas e ausente entre os continentes mencionados.

A Distant Shore tem seu lugar na linhagem de romances com sólido lastro narrativo, associa-se à "arte que é forma cognitiva, percepção do real histórico e psicológico, mímesis. $"{ }^{170}$. O fato de dar forma verossímil à ficcionalização de duas histórias de vida que se entretecem, se aproximam, se afastam e se expandem também através da problemática relação com os espaços de uma geografia humana que simbolizam - questão histórica premente do tempo em que vivemos - se alia ao fato de apresentar uma intrincada concatenação, que é a viga-mestra de sustentação das muitas unidades narrativas menores que se interligam internamente em cada um dos segmentos maiores claramente demarcados e, ao longo e através deles, estabelecendo uma crescente irradiação de sentidos. Os discursos em primeira pessoa criados para os protagonistas, os estilos de linguagem de cada um aparecem

167 Maciel, Nahima. "Literatura das Diferenças - Entrevista com Caryl Phillips". Correio Braziliense. Brasília, Caderno C, p. 5, 2 de julho de 2006.

168 Vinuesa, Maya G.. "In conversation with Caryl Phillips". Afroeuropa: Journal of Afroeuropean Studies, 23 de outubro de 2007.

169 Maingueneau, Dominique. “A duplicidade enunciativa”. In: O Contexto da Obra Literária. São Paulo:

Martins Fontes, 1995, pp. 171,172.

170 Bosi, Alfredo. Reflexões Sobre A Arte. São Paulo: Editora Ática, 1986, p. 44. 
intercalados com o discurso do narrador em terceira pessoa, elemento que se flexibiliza dentre outras funções para, de certa forma, dirigir a leitura ora em direção à empatia, ao reconhecimento catártico, ora em direção a uma compreensão apoiada em um afastamento, que pode resultar em distanciamento crítico. 


\section{BIBLIOGRAFIA}

ADORNO, T. W., Morals and Criminality. In: Notes to Literature III. v. ii. (traduzido do alemão para o inglês por Shierry Weber Nicholsen) Nova Yorque: Columbia University Press, 1992.

. Em memória de Eichendorf. In: Notas de Literatura I. (trad. De Jorge de Almeida). São Paulo: Duas Cidades/Editora 34, 2003.

ARRIGUCCI JÚNIOR, Davi. Entrevista com Davi Arrigucci Junior. Magma-Revista. $\mathrm{n}^{\mathrm{o}} 4$, São Paulo: Humanitas, 1977.

AUBRETON, Robert. Dados Religiosos: os Heróis. In: Introdução a Homero. São Paulo: Difusão Européia do Livro/Edusp, 1968.

BAKHTIN, Mikhail. Discourse in the Novel. In: The Dialogic Imagination. Ed..e trad.por Michael Holquist. Austin: University of Texas Press, 1990.

BEAH, Ishmael. A long way gone: memoirs of a boy soldier. Nova Yorque: S. Crichton Books/Farrar, Straus e Giroux, 2007.

BENJAMIN, Walter. Sobre o Conceito de História. Magia e Técnica, Arte e Política. [trad. de Sérgio Paulo Rouanet e prefácio de Jeanne Marie Gagnebin]. (10 reimpressão da edição de 1985). São Paulo: Editora Brasiliense, 1996.

A crise do romance - sobre Alexanderplatz de Döblin. Magia e Técnica, Arte e Política. São Paulo, Editora Brasiliense, 1996.

BOSI, Alfredo. Reflexões Sobre A Arte. São Paulo: Editora Ática, 1986.

. Dialética da Colonização. São Paulo: Companhia das Letras, 1993.

COHEN, Robin. Labour and Imperial Diasporas: Indians and British. In: Global Diasporas. Seattle: University of Washington Press, 1997.

CRUZ, Leonardo. Intolerância cresce no norte da Inglaterra. Folha de São Paulo, caderno A, p. 17,15 de julho de 2001 .

DAVIES, Mike. Planeta Favela. São Paulo: Boitempo Editorial, 2006.

DU BOIS, W. E. B. [1903] The Souls of Black Folk. Londres: Dover Publications, 1994.

EAGLETON, T et. al (orgs). Marxist Literary Theory. Oxford: Blackwell, $1996 .$.

ELIADE, Mircea. Cofradias de hombres y sociedads secretas de mujeres. In: Lo Sagrado y lo 
Profano. Madri: Ediciones Guadarrama, 1973.

FANON, Frantz [1952]. Black Skin, White Masks. (Trad. do francês para o inglês por Charles Lam Markmann e prefácio de H. K. Bhabha). Londres: Pluto Press, 1986.

FOUCAULT, Michel. Microfisica do Poder. Rio de Janeiro: Graal Editores, 1998.

GILROY, Paul. The Empire Strikes Back: Race and Racism in 70s Britain. Londres \& Nova Yorque: Routledge in association with The Centre for Contemporary Cultural Studies of Birmingham, 1982.

. There Ain't no Black in the Union Jack: The Cultural Politics of Race and Nation. Chicago: University of Chicago Press, 1991.

. Uma história para não se passar adiante. In: O Atlântico Negro: Modernidade e Dupla Consciência. (trad. De Cid K. Moreira). São Paulo: Editora 34, 2001.

. It ain't where you're from, it's where you're at. In: Small Acts. Londres: Serpent's Tail, 2000.

Living Memory: Meeting Toni Morrison. In: Small Acts. Londres: Serpent's Tail, 2000.

HALL, Stuart. O global, o local e o retorno da etnia. In: A Identidade Cultural na Pósmodernidade (trad. de Tomaz Tadeu da Silva e de Guacira Lopes Louro). Rio de Janeiro: D P \& A editora, 1999.

HEGEL, G. W. F.. Lectures on the Philosophy of History (1830-1831). (trad. de J. Sibree). Nova Yorque: Dover, 1956.

HOBSBAWM, Eric. [1968]. Da Revolução Industrial Inglesa ao Imperialismo (trad. de D. M. Garschagen do original Industry and Empire). Rio de Janeiro: Editora Forense Universitária, $5^{\mathrm{a}}$ edição brasileira, 2000.

. Cold War. In: The Age of Extremes: The Short Twentieth Century 1914-1991. Nova Yorque : Vintage Books, 1995.

. The Social Revolution. In: The Age of Extremes. Nova Yorque: Vintage Books, 1995.

. Cultural Revolution. In : The Age of Extremes. Nova Yorque: Vintage Books, 1995.

. The Third World. In: The Age of Extremes. Nova Yorque: Vintage Books, 1995.

. The Crisis Decades. In: The Age of Extremes. Nova Yorque: Vintage Books, 1995.

JAGGI, Maya. [1996]. The Final Passage: an intervew with Caryl Phillips. In: OWUSU, Kwesi. Black British Culture \& Society. Londres: Routledge, 2000.

JAMESON, Fredric. The Political Unconscious. Ithaca, Nova Yorque: Cornell University 
Press, 1985.

. Notes on Globalization as a Philosophical Issue. In:The Cultures of Globalization. Durham \& Londres: Duke University Press, 1998.

LAVERY, Clare. The North-South Divide. In: Focus on Britain Today. Londres: Macmillan, 1993.

LODGE, David. The Novelist at the Crossroads. Londres \& Nova Yorque: Routledge, 1986.

LUKÁCS, Georg. The Ideology of Form. In: EAGLETON, T. e MILNE, D. (orgs) Marxist Literary Theory. Oxford: Blackwell, 1996.

MACIEL, Nahima. Literatura das Diferenças: entrevista com Caryl Phillips. Correio Braziliense. Caderno C, Brasília, 2 de julho de 2006.

MAINGUENEAU, Dominique. A Duplicidade Enunciativa. In: O Contexto da Obra literária. São Paulo: Martins Fontes, 1995.

MORRISON, Toni. Living Memory: Meeting Toni Morrison. In: GILROY, P. Small Acts. Londres: Serpent's Tail, 2000.

MOTA, Carlos Guilherme. Você também está atrás das grades. Entrevista concedida a Fred Melo Paiva. O Estado de São Paulo. Caderno Aliás, J4, 9 de dezembro de 2007.

MURFIN, Ross C.. (org.) Case Studies in Contemporary Criticism: Heart of Darkness. Joseph Conrad. Boston \& New York: Bedford Books of St. Martin's Press, 1996.

NAIRN, Tom. The English Literary Intelligentsia. Bananas Literary Supplement, [s.1.] 1971.

OLIVEIRA, Francisco de. 1968-2008 Acima de tudo uma rebeldia política.. Entrevista concedida a Antonio Gonçalves Filho. O Estado de São Paulo, caderno Cultura, D 13, 11 de maio de 2008.

OWUSU, Kwesi (org) Black British Culture \& Society. Londres \& Nova Yorque: Routledge, 2000.

PEDREIRA, Márcia. Trilhas pela Água: história e ficção em Crossing the River de Caryl Phillips. Dissertação de Mestrado. Faculdade de Filosofia, Letras e Ciências Humanas da Universidade de São Paulo, fevereiro de 2003.

PHILLIPS, Caryl. The Final Passage. Londres: Faber \& Faber, 1985. Higher Ground. Londres: Viking, 1989.

. Cambridge. Nova Yorque: Vintage International, 1991.

. Crossing the River. Londres:Bloomsbury, 1993.

. The Nature of Blood. Londres: Faber \& Faber, 1997. 
. Extravagant Strangers. Nova Yorque: Vintage International, 1997.

. A Distant Shore. Londres: Vintage, 2004.

. The Final Passage: an interview with Caryl Phillips. Entrevista concedida a Maya Jaggi [1996]. In: OWUSU, Kwesi (org.). Black British Culture \& Society. Londres: Routledge, 2000.

. Finding Oneself at Home. timesonline.co.uk/ articles. Acessado em 15 fev. 2006.

. Literatura das Diferenças: entrevista com Caryl Phillips. Entrevista concedida a

Nahima Maciel. Correio Braziliense. Brasília, 2 de julho de 2006.

. In conversation with Caryl Phillips. Entrevista concedida a Maya G. Vinuesa.

Afroeuropa: Journal of Afroeuropean Studies, 23 de outubro de 2007.

READER, John. Africa: a Biography of the Continent. Londres: Penguin, 1998.

RIBEIRO, Wagner da Costa. Relações Internacionais: Cenários para o Século XXI. São Paulo: Editora Scipione, 2004.

. Relações entre espaço e poder no mundo globalizado. O Estado de São Paulo. Caderno Cultura, D7, 18 de maio de 2008.

ROOM, Adrian (org.). Dictionary of Britain. Oxford: Oxford University Press, 1990.

RUSHDIE, Salman. An Unimportant Fire. Imaginary Homelands: Essays and Criticism 1981-1999. Londres: Granta Books/ Penguin, 1991.

. The New Empire Within Britain. Imaginary Homelands. Londres: Granta Books/Penguin, 1991.

. Where is the honour in this vile code that condemns women to shame?. The Guardian. Londres, 30 de março de 2005.

SALLA, Fernando. Afinal, quanto falta para o fundo do poço?.O Estado de São Paulo. Caderno Aliás, J 5, 9 de dezembro de 2007.

SANTOS, Boaventura de Sousa. Pela Mão de Alice: o Social e o Político na PósModernidade. São Paulo: Editora Cortez, 1997.

SERRANO, Carlos e WALDMAN, Maurício. Memória d'África. São Paulo: Cortez Editora, 2007.

SIVANANDAN, A . .The Struggle for a Radical Black Political Culture: an interview with ${ }^{\text {a }}$ Sivanandan. In: OWUSU, Kwesi. Black British Culture and Society. Londres: Routledge, 2000.

SMITH, Zadie. Uma semana pelas veias abertas da Libéria. O Estado de São Paulo. Caderno 
Aliás, J 5, 10 de junho de 2007.

SOLMI, Sérgio.[1954] Prefácio a Minima Moralia [de T. W. Adorno]. Turim: Einaudi, 1954. SPIVAK, Gayatri. Can the Subaltern Speak? Speculation on Widow Sacrifice. Wedge. 7/8 Winter/Spring, 1985.

SPURR, David[1993]. Negation. In: The Rhetoric of Empire: Colonial Discourse in journalism, Travel, Writing and Imperial Administration. Durham \& Londres:Duke University Press, 1994.

STORRY, Mike \& CHILDS, Peter (orgs). British Cultural Identities. Londres \& Nova Yorque: Routledge, 1997.

VASCONCELOS, Sandra Guardini. Um Problema Crítico. Formação do Romance Inglês: Ensaios Críticos. São Paulo: Editora Hucitec e Fapesp, 2007.

VINUESA, Maya G.. In conversation with Caryl Phillips. Afroeuropa: Journal of Afroeuropean Studies, 23 de outubro de 2007.

Mais informações disponíveis na internet:

www.carylphillips.com 